\title{
Identifying and Preserving High-Water Mark Data
}

Chapter 24 of

Section A, Surface-Water Techniques

Book 3, Applications of Hydraulics
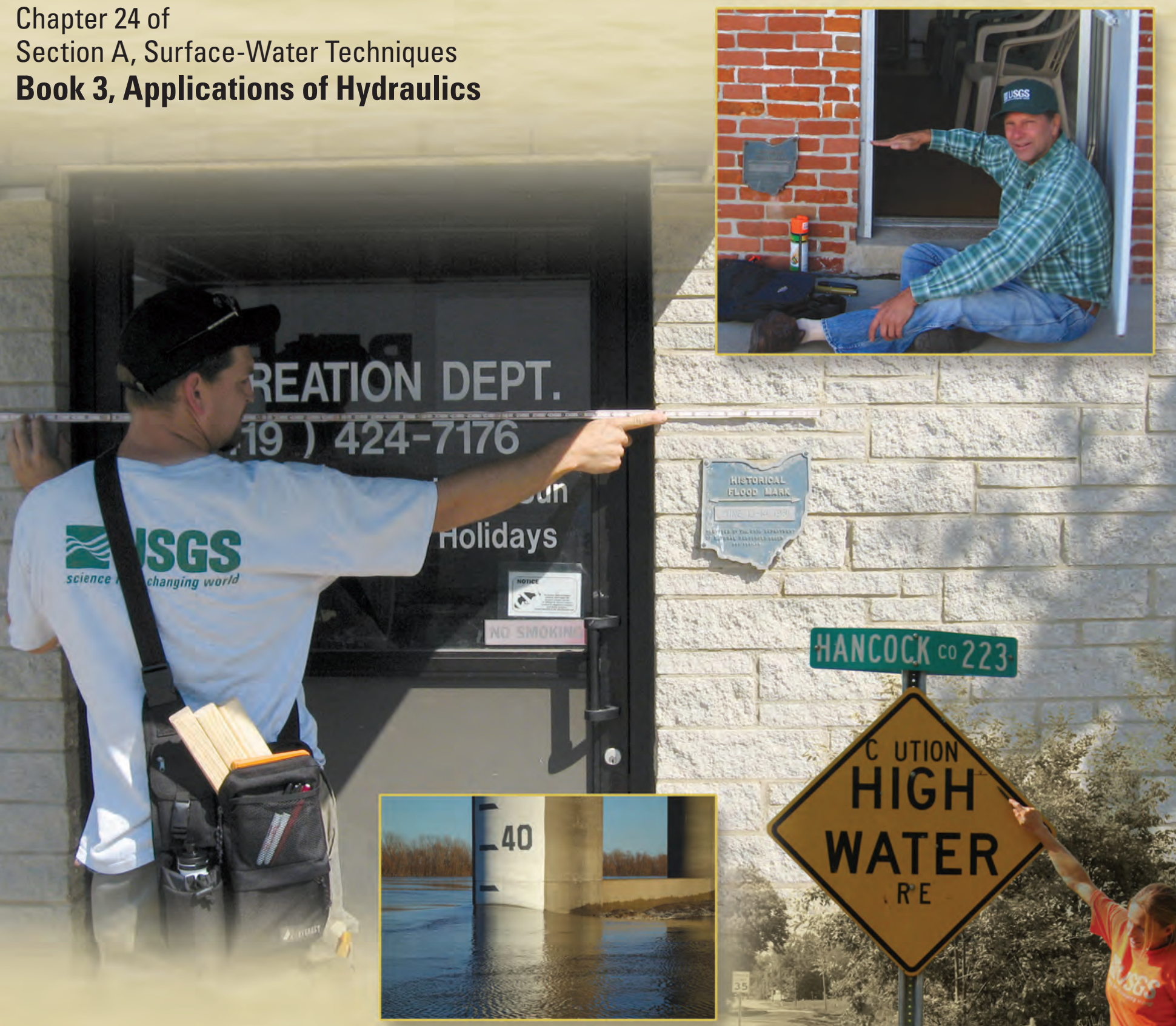

Techniques and Methods 3-A24

U.S. Department of the Interior

U.S. Geological Survey 
Cover. Top banner: Flood damage after the Great Miami hurricane of 1926 in Miami, Fla. Photograph by R.S. Clements.

Center: USGS hydrographer compares 1981 historical flood marker to 2007 high-water mark. Photograph by Rob Darner.

Upper right: USGS hydrographer compares 1981 historical marker to 2007 high-water mark. Photograph by Carrie Huitger.

Lower left: Interstate 57 bridge pier on the Mississippi River during the winter floods of 2015-2016. Photograph by Kevin Oberg.

Lower right: USGS hydrographer identifies a high-water mark. Photograph by Jim Sherwood. 


\section{Identifying and Preserving High-Water Mark Data}

By Todd A. Koenig, Jennifer L. Bruce, Jim 0'Connor, Benton D. McGee, Robert R. Holmes, Jr., Ryan Hollins, Brandon T. Forbes, Michael S. Kohn, Mathew F. Schellekens, Zachary W. Martin, and Marie C. Peppler

Chapter 24 of

Section A, Surface-Water Techniques

Book 3, Applications of Hydraulics

Techniques and Methods 3-A24 


\section{U.S. Department of the Interior SALLY JEWELL, Secretary}

\section{U.S. Geological Survey Suzette M. Kimball, Director}

\section{U.S. Geological Survey, Reston, Virginia: 2016}

For more information on the USGS - the Federal source for science about the Earth, its natural and living resources, natural hazards, and the environment—visit http://www.usgs.gov or call 1-888-ASK-USGS.

For an overview of USGS information products, including maps, imagery, and publications, visit http://www.usgs.gov/pubprod/.

Any use of trade, firm, or product names is for descriptive purposes only and does not imply endorsement by the U.S. Government.

Although this information product, for the most part, is in the public domain, it also may contain copyrighted materials as noted in the text. Permission to reproduce copyrighted items must be secured from the copyright owner.

Suggested citation:

Koenig, T.A., Bruce, J.L., O'Connor, J.E., McGee, B.D., Holmes, R.R., Jr., Hollins, Ryan, Forbes, B.T., Kohn, M.S., Schellekens, M.F., Martin, Z.W., and Peppler, M.C., 2016, Identifying and preserving high-water mark data: U.S. Geological Survey Techniques and Methods, book 3, chap. A24, 47 p., http://dx.doi.org/10.3133/tm3A24.

ISSN 2328-7047 (print)

ISSN 2328-7055 (online)

ISBN 978-1-4113-4030-5 


\section{Preface}

This series of manuals on Techniques and Methods (TM) describes approved scientific and datacollection procedures and standard methods for planning and executing studies and laboratory analyses. The material is grouped under major subject headings called "books" and further subdivided into sections and chapters. Section A of book 3 is on surface-water techniques.

The unit of publication, the chapter, is limited to a narrow field of subject matter. These publications are subject to revision because of experience in use or because of advancement in knowledge, techniques, or equipment, and this format permits flexibility in revision and publication as the need arises. Chapter A24 of book 3 (TM 3-A24) deals with proper identification, evaluation, and temporary preservation of perishable high-water marks for data collection and use as discussed in many of the other chapters in this section. In addition, an appendix introduces the identification of persistent paleoflood evidence left by historical floods.

This first edition of "High-Water Mark Identification and Preservation" is published online at http://dx.doi.org/10.3133/tm3a24 and is for sale by the U.S. Geological Survey, Science Information Delivery, Box 25286, Federal Center, Denver, Colorado 80225. 


\section{Acknowledgments}

The authors would like to thank the Surface Water Specialists of the U.S. Geological Survey Water Science Field Team for their technical review and considerable contributions to this manual: Larry Bohman, Mark Smith, Terry Kenney, and Karl Winters. Technical review was also provided by Chad Ostheimer and Scott Hedgecock, without whom many details would have been overlooked. Except where noted in the figure captions, photographs were provided by the authors, who would also like to thank the following photograph contributors: Heather Best, R.S. Clemonts, Pat Coate, Tim Cohn, Rob Darner, Burl B. Goree, Brent Hanson, Carrie Huitger, Jarvis Kaderlik, Michelle Kang, Walter Killion, Richard Kittleson, R. Russell Lotspeich, Jon Mason, Emmet McGuire, Toby Minear, Brian Moore, Kevin Oberg, Chad Ostheimer, Craig Painter, Ben Rivers, Bret Robinson, Paul Rydlund, David C. Sasser, Jr., Jim Sherwood, Nathan Stroh, William C. Vervaeke, Aub N. Ward, Robert Webb, Christopher Wilkowske, and Karl Winters. 


\section{Contents}

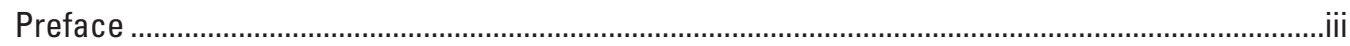

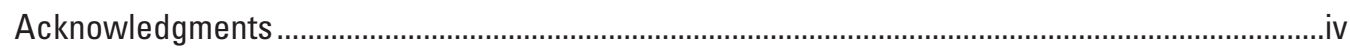

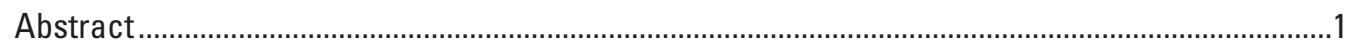

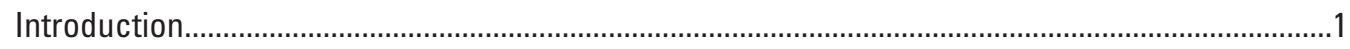

High-Water Mark Field Guide—Identifying Evidence of High Water .............................................. 2

Tranquil-Water High-Water Marks .............................................................................................

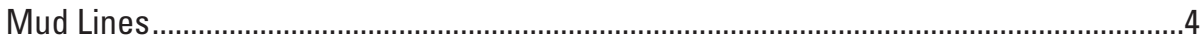

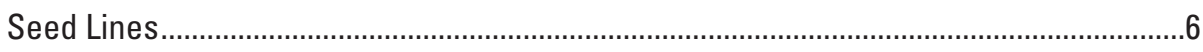

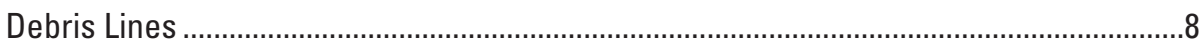

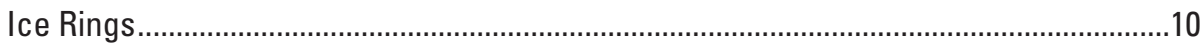

Rapid-Water High-Water Marks .........................................................................................11

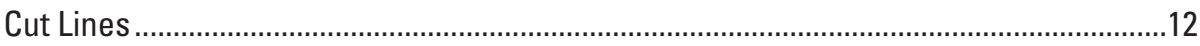

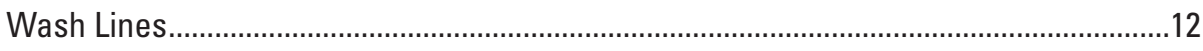

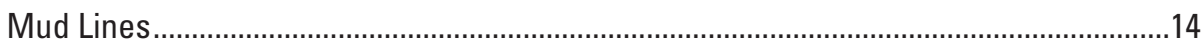

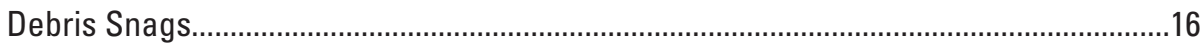

Engineered High-Water Mark Indicators ……………...................................................19

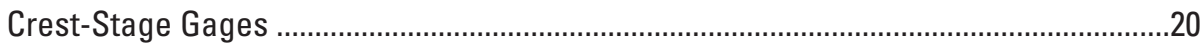

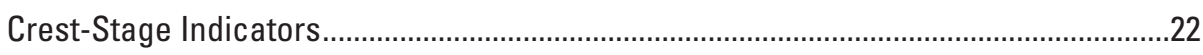

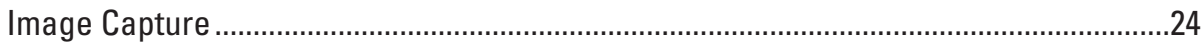

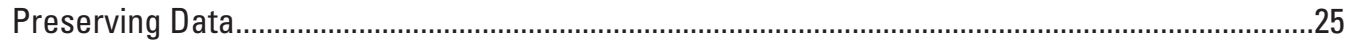

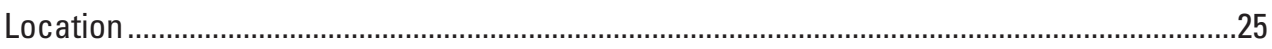

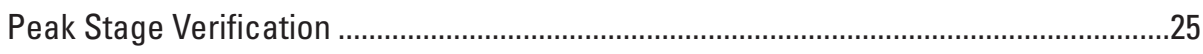

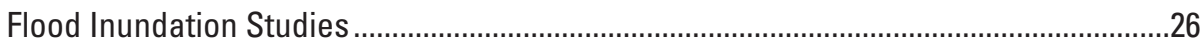

Indirect Streamflow Measurements ........................................................................26

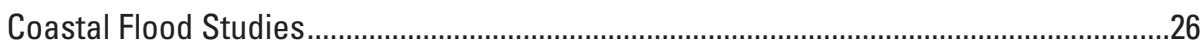

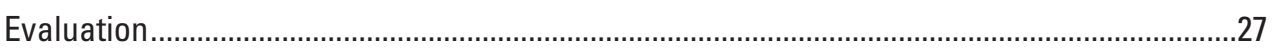

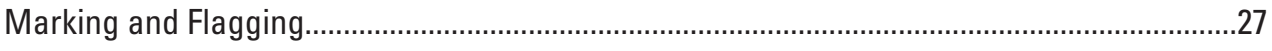

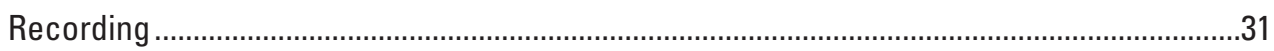

Best Practices_-Developing an Eye for Good High-Water Marks and Avoiding Pitfalls................34

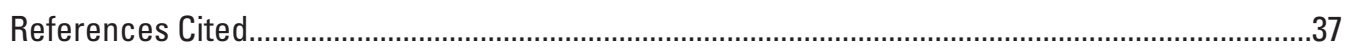

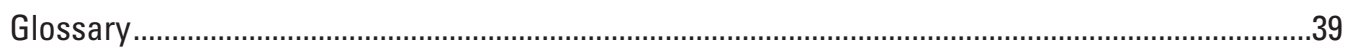

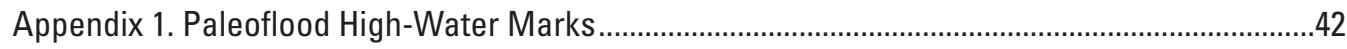

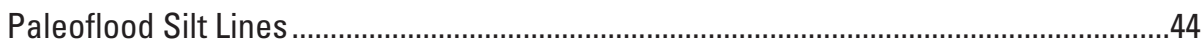

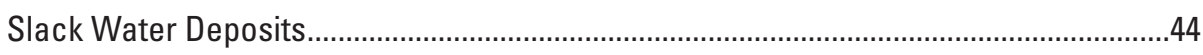

Other Paleoflood Evidence..........................................................................................45 


\section{Figures}

1. Photograph showing a mud line visible from a distance on desert shrubs........................4

2. Photograph showing a mud line inside a previously flooded structure .............................4

3. Photograph showing a well-defined mud line left on the interior side of a glass wall

4. Photograph showing a foam line that was left on a bridge pier as floodwaters receded.

5. Photograph showing a stain line on a wood door that has absorbed floodwater ............5

6. Photographs showing seed lines on the inner surfaces of a restroom and a utility room

7. Photographs showing seed lines on the surfaces of a recreational sign and a home exterior

8. Photographs showing well-defined seed lines on large tree trunks.

9. Photograph showing a thick seed line formed on the underside of a tree that fell before the flood

10. Photographs showing debris lines formed on grassy overbanks, a roadway, and a grassy highway embankment.

11. Photograph showing floating debris as it collects into a small debris line as floodwaters recede.

12. Photograph showing a hydrographer surveying the landward edge of a debris line

13. Photographs showing ice rings formed around trees, ice rings formed around a fence post caused by multiple freezes and thaws, and delicate ice rings preserved in shoreline grasses

14. Photograph showing ice rings on hanging limbs above a fast flowing stream ...............10

15. Photograph showing a hydrographer preparing to survey a cut line in a sand/clay bluff.

16. Photograph showing a snow-based cut line

17. Photograph showing the difference in texture between the rough, nonflooded portions and the smooth, flooded portions of an arid stream bank.

18. Photograph showing a hydrographer flagging a wash line that was created when floodwaters removed a thick bed of needles revealing the soil underneath

19. Photograph showing a folded-grass wash line, marked by the boundary between grasses that were bent by floodwaters and grasses that were not flooded...................13

20. Photograph showing a wash line obscured by new growth ..........................................13

21. Photograph showing a rapid-water mud line of a different color than the existing bed sediment

22. Photograph showing unreliable mud lines created by wave action on a bridge pier.

23. Photographs showing debris snags on a utility pole cable, house supports, a bridge pier, and a partially submerged tree.

24. Photograph showing significant runup and drawdown caused by swift flows around a tree.

25. Photograph showing a line of debris collected along a chain-link fence .......................18

26. Photograph showing small trees that have been bent down by the force of the floodwaters 
27. Diagrams illustrating how debris deposited onto bendable shrubs or hanging branches during a flood can result in misleading high-water marks when the shrub or branch returns to its original position after floodwaters recede......

28. Diagram illustrating a typical crest-stage gage .............................................................20

29. Photograph showing a cork line from a crest-stage gage ...........................................21

30. Photographs showing crest-stage gages mounted on the downstream side of a bridge pier, mounted to a tree, and mounted to a wingwall in the drawdown zone where the gage cannot collect the proper headwater elevation.....................................21

31. Diagram illustrating a stilling well with steel tape shaft encoder and high-water indicator clip during normal flow conditions and during flood conditions .......................22

32. Photograph showing a crest-stage indicator under a bridge pier...................................23

33. Photograph showing a hydrographer measuring a chalk line high-water mark .............23

34. Screen capture of a U.S. Geological Survey South Atlantic Water Science Center live webcam.

35. Photographs showing markers for recording high-water marks: a nail and bright-colored tape used to mark seed lines on bamboo; flagging tape and U.S. Geological Survey marking tabs; a wire flag marking a debris line on the ground; and a spray painted line (using a straight edge) marking a precise high-water mark on a concrete divider.

36. Photographs showing a hydrographer transferring a high-water mark around the corner of a structure using a simple carpenter's level for easier surveying.

37. Photograph showing a hydrographer providing a written description of a flagged high-water mark using a white board.

38. An example of a paper field form for recording high-water marks and an electronic form for recording high-water marks in an online system

39. Photograph showing a debris pile in a tree with a snake napping in an upper branch

40. Photograph showing a road washout just downstream from a livestock farm on St. Vrain Creek, Colorado .35

41. Photograph showing a debris snag and two seed lines ................................................35

42. Photograph showing structures with high-water marks that have likely moved during the flood, making peak water surface uncertain ...................................................35

43. Photographs showing seed lines formed on the outside of a structure and inside an enclosure attached to the structure ...........................................................................

44. Photograph showing a plot of high-water marks created in the field .............................36

\section{Appendix Figures}

1-1. Stream cross-section diagram illustrating types of geologic and biologic evidence left by floods .. .42

1-2. Photograph showing silt lines and slack water sediment deposited in a dry alcove .....44

1-3. Photograph showing a scour line and slack water sediment accumulation in a small tributary junction flowing left to right

1-4. Photographs showing silty flood deposits with mud-cracked caps that were deposited in a small alcove and the sedimentology of these deposits showing climbing ripple cross stratification, an indication of high rates of sedimentation by a current moving left to right

1-5. Photographs showing paleoflood evidence on trees 


\section{Tables}

1. Publications of indirect measurement techniques including the proper location of high-water marks.

2. High-water mark uncertainty shorthand ……..........................................................28

\section{Narrative Sidebars}

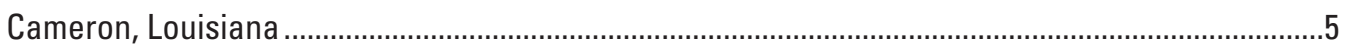

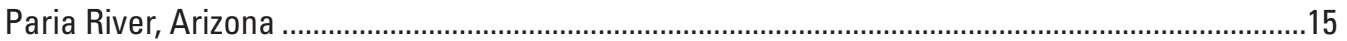

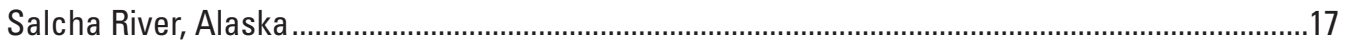

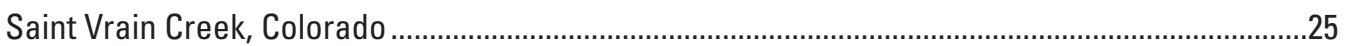

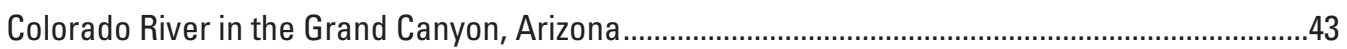

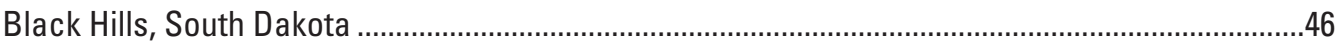

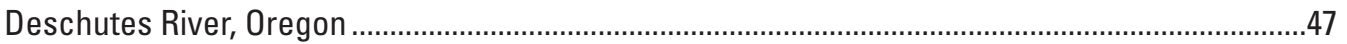

\section{Conversion Factors}

U.S. customary units to International System of Units

\begin{tabular}{|c|c|c|}
\hline Multiply & By & To obtain \\
\hline \multicolumn{3}{|c|}{ Length } \\
\hline inch (in.) & 2.54 & centimeter $(\mathrm{cm})$ \\
\hline foot $(\mathrm{ft})$ & 0.3048 & meter $(\mathrm{m})$ \\
\hline mile (mi) & 1.609 & kilometer (km) \\
\hline yard (yd) & 0.9144 & meter $(\mathrm{m})$ \\
\hline \multicolumn{3}{|c|}{ Area } \\
\hline square mile $\left(\mathrm{mi}^{2}\right)$ & 2.590 & square kilometer $\left(\mathrm{km}^{2}\right)$ \\
\hline
\end{tabular}

\section{Datum}

Vertical coordinate information is referenced to the North American Vertical Datum of 1988 (NAVD 88). 


\title{
Identifying and Preserving High-Water Mark Data
}

\author{
By Todd A. Koenig, Jennifer L. Bruce, James E. O'Connor, Benton D. McGee, Robert R. Holmes, Jr., \\ Ryan Hollins, Brandon T. Forbes, Michael S. Kohn, Mathew F. Schellekens, Zachary W. Martin, and \\ Marie C. Peppler
}

\section{Abstract}

High-water marks provide valuable data for understanding recent and historical flood events. The proper collection and recording of high-water mark data from perishable and preserved evidence informs flood assessments, research, and water resource management. Given the high cost of flooding in developed areas, experienced hydrographers, using the best available techniques, can contribute high-quality data toward efforts such as public education of flood risk, flood inundation mapping, flood frequency computations, indirect streamflow measurement, and hazard assessments.

This manual presents guidance for skilled high-water mark identification, including marks left behind in natural and man-made environments by tranquil and rapid flowing water. This manual also presents pitfalls and challenges associated with various types of flood evidence that help hydrographers identify the best high-water marks and assess the uncertainty associated with a given mark. Proficient high-water mark data collection contributes to better understanding of the flooding process and reduces risk through greater ability to estimate flood probability.

The U.S. Geological Survey, operating the Nation's premier water data collection network, encourages readers of this manual to familiarize themselves with the art and science of high-water mark collection. The U.S. Geological survey maintains a national database at http://water.usgs.gov/floods/ $\mathrm{FEV} /$ that includes high-water mark information for many flood events, and local U.S. Geological Survey Water Science Centers can provide information to interested readers about participation in data collection and flood documentation efforts as volunteers or observers.

\section{Introduction}

Flooding along streams, rivers, lakes, and oceans is a natural process. Because humans live and work near these bodies of water, flooding can result in significant effects including the loss of life and property; in the 1990s, flood losses in the United States amounted to about $\$ 50$ billion (Pielke and others, 2002). Understanding where floods occur and determining how much damage floods cause are crucial to assessing risk, lessening effects, and mitigating loss (Association of State Floodplain Managers, 2014); documenting flood levels is an important part of these endeavors. The identification and recovery of post-flood evidence that marks the highest elevation of floodwaters, called a high-water mark, can provide important insight into understanding, communicating, modeling, and predicting flood phenomena (Benson and Dalrymple, 1984).

High-water marks are useful for a variety of educational and scientific efforts. Prominent identification of high-water marks left behind after a major riverine flood or storm tide, through signage or other means, can be a powerful public education tool, reminding viewers about the dangers of floods and the caution that should be taken when encountering floodwaters. High-water marks and, particularly, the water surface profiles that the high-water marks imply are used to verify hydraulic model analyses at targeted reaches of rivers and streams. These hydraulic models, in turn, are used for the construction of flood-inundation maps, which can be used for land-use management, emergency management, and flood insurance rate determination. Hydraulic models are also used for flood warning systems, hydraulic design of drainage structures, and other flood mitigation efforts. 
High-water marks play an important role in computing and preserving U.S. Geological Survey (USGS) stage and streamflow data. Knowledge of streamflow (in the form of a time series of streamflow or the peak value during a flood) is essential to water resource management and science. Because continuous, direct streamflow measurement is impractical, the USGS produces real-time streamflow data through a tool called a streamflow rating curve (Rantz and others, 1982). The rating curve relates streamflow to readily measurable surrogates such as water surface elevation (stage), velocity, and water surface slope, which are collected at a streamgage. Streamgages continuously monitor stream stage, and highwater marks are collected as an independent verification of the sensors that determine the peak stage of recent events.

The preferred method of constructing a streamflow rating curve involves onsite direct measurements of streamflow at various stages and times of the year. Pairs of measured stages and streamflows are plotted on a graph, and a rating curve is developed, mathematically or graphically, to connect the points. However, direct measurements of streamflow are not always possible during a flood event; therefore, indirect measurements of peak streamflow may be made after the event. Indirect measurements may form important data points in otherwise-undefined sections of a rating curve. These measurements use high-water marks to establish boundary conditions and determine a water surface slope, which is an indicator of the flood's kinetic energy. Indirect measurement computations use the concepts of conservation of energy and mass to estimate the peak streamflow value from surveys of high-water marks, channel geometry, and structure geometry, and from an estimate of the channel and overbank roughness. The accuracy of high-water mark measurements strongly influences the accuracy of each indirect streamflow computation (Benson and Dalrymple, 1984).

Floods may leave behind many types of high-water marks. Proper identification of the marks requires experience and an understanding of how floodwaters create them. Most high-water marks are perishable and degrade rapidly because of factors such as wind, rain, gravity, dew cycles, and human disturbance. Even rapid vegetation growth can displace highwater marks. Therefore, rapid identification of marks after a flooding event is crucial to collecting the elevation data reflected by the marks.

This manual outlines various types of high-water marks and provides practical guidance on their identification, evaluation, and preservation. The appendix provides an additional introduction to well-preserved historical high-water information called paleoflood data. Although high-water marks are essential to the practices of peak verification, indirect streamflow measurement, inundation mapping, and hydraulic modeling, this manual does not cover these topics in-depth. References on these topics, however, are provided throughout this report.

\section{High-Water Mark Field Guide- Identifying Evidence of High Water}

Field experience is the best training for high-water mark hunting. The photographs and descriptions presented in this manual are designed to accompany actual investigations and accelerate the process of learning the art of identifying highwater marks and the science of evaluating high-water mark usefulness. Expertise in high-water mark hunting equips the hydrographer for verifying streamgage records and supplying valuable data for flood characterization and modeling. The high-water marks described in this guide are divided generally into two types: high-water marks commonly formed in still or slow-moving water ("tranquil-water high-water marks") and high-water marks commonly formed in fast-moving water ("rapid-water high-water marks"). High-water mark descriptions within these two general classifications are followed by a discussion of engineered high-water collection methods, and an appendix at the end of this manual describes historically persistent, paleoflood evidence.

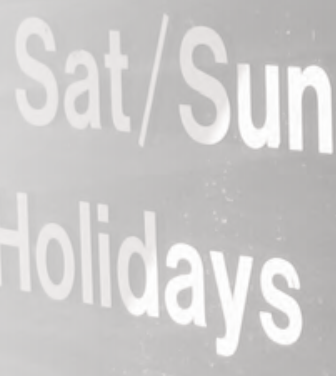




\section{Tranquil-Water High-Water Marks}

By nature, tranquil water presents a smooth horizontal surface. High-water marks left behind by tranquil water have a similarly smooth trend, typically with much smaller uncertainties than those left behind by rapid flow. For this reason, tranquil-water high-water marks, if available, may be more useful than rapid-water high-water marks. Even in swift-moving floods, tranquil areas frequently dot the stream edge where changes in channel geometry or large flow obstructions have created regions of ineffective flow. The following sections describe typical categories of high-water marks in tranquil reaches.

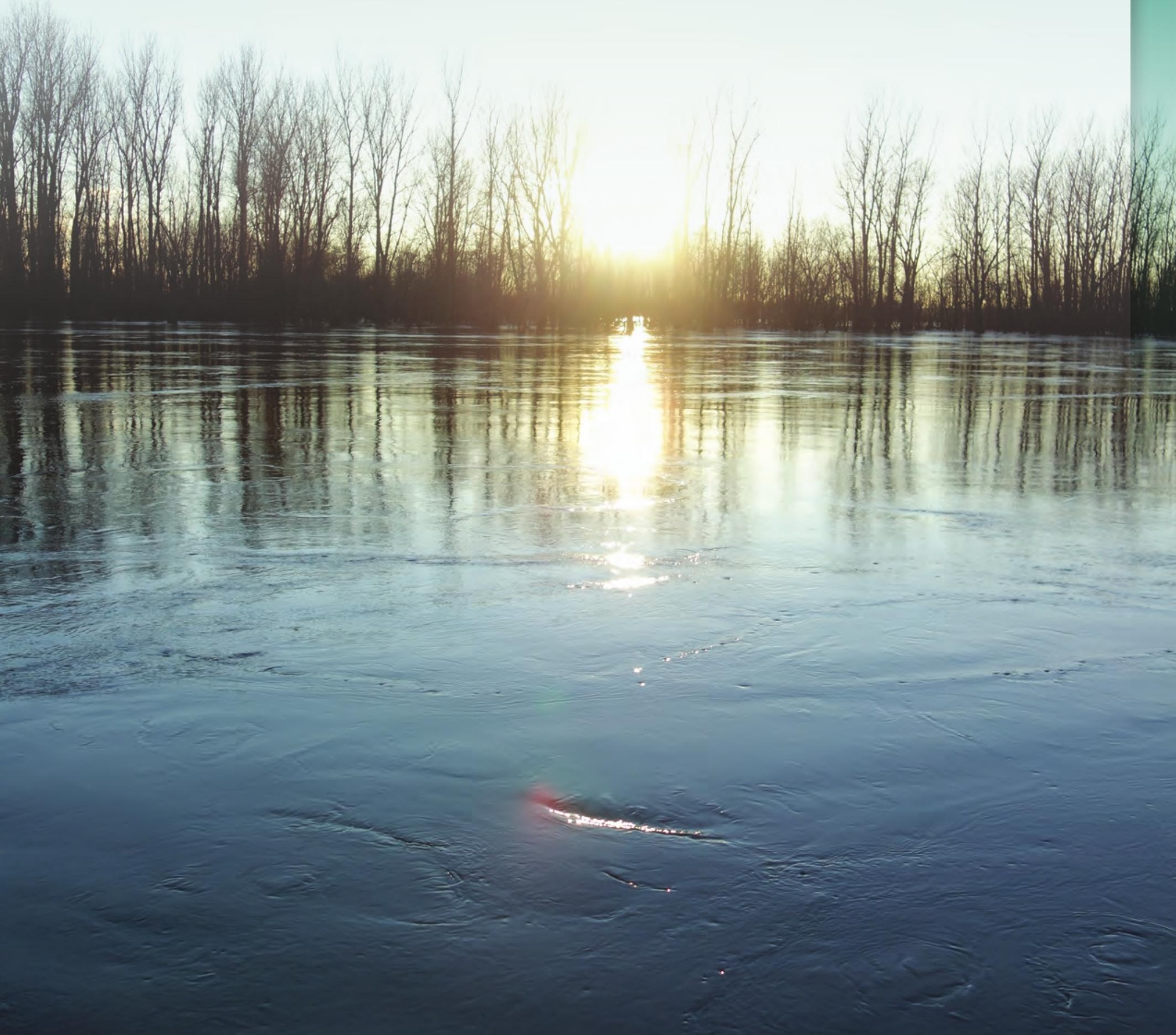




\section{Mud Lines}

When turbid water comes into contact with natural and man-made objects, the water can leave a film on the outside of nonporous surfaces called a "mud line" (or sometimes "foam line" or "stain line" as discussed in the next paragraph). Mud lines on natural surfaces such as grasses, shrubs, and trees can form usable high-water marks, and the lines are typically easier to see when viewed from a distance, such as the desert shrubs shown in figure 1.

Mud lines on hard surfaces tend to leave better-quality high-water marks, especially when deposited by tranquil water inside structures (fig. 2). Excellent mud lines can form on stone, metal, plastic, and glass surfaces, such as the mud line shown in figure 3. Mud lines on structures may last for many weeks if undisturbed or may be washed away quickly during cleanup efforts. Mud lines on outside surfaces, including plants and structures, are susceptible to removal by subsequent rains.

If mud lines are deposited inside a protective structure, the elevation indicated by those lines will only be reliable if sufficient hydraulic connection during the flood caused the inside of the structure to attain a peak water surface equal to the peak water surface outside of the structure. Mud lines that represent a water surface elevation that is lower than high-water marks outside the structure usually indicate a poor

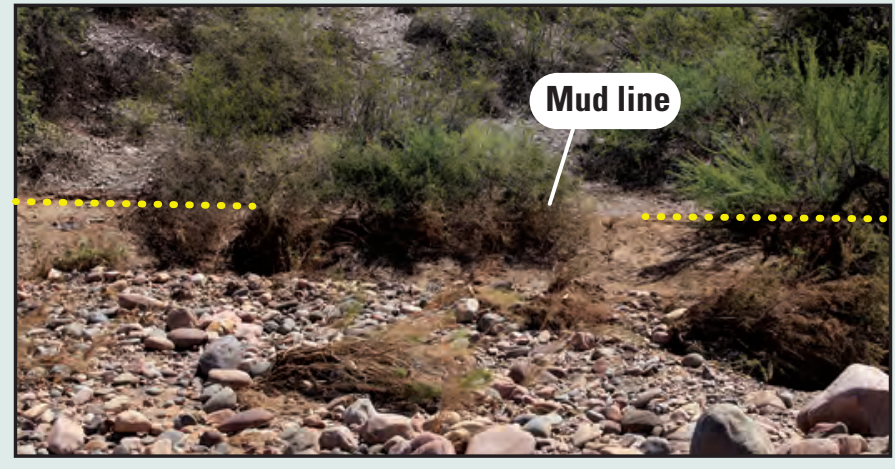

Figure 1. A mud line visible from a distance on desert shrubs. Sediment from the floodwaters has deposited onto the shrubs, turning them brown.

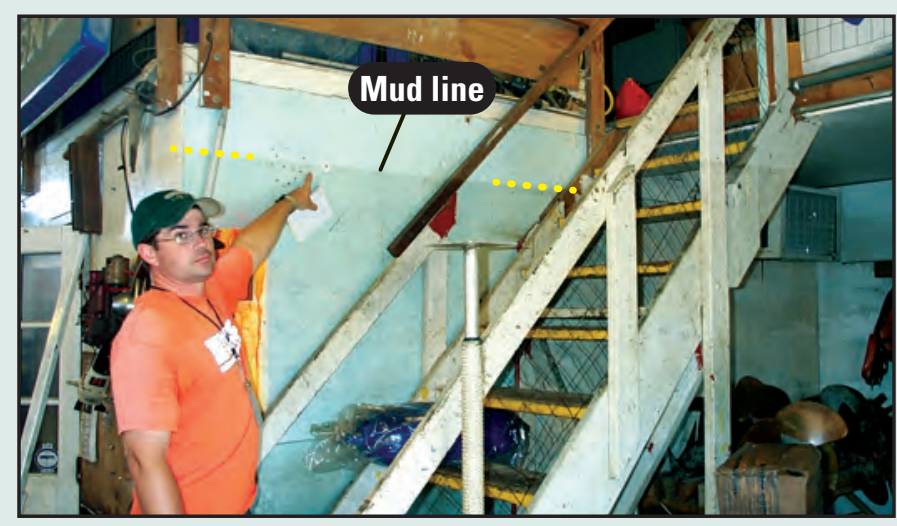

Figure 2. A mud line inside a previously flooded structure. hydraulic connection between the outside and inside of the structure (see "Cameron, Louisiana" narrative). In addition, smaller enclosures that are tightly sealed above the water line may hold an air pocket large enough to resist complete infilling of water, causing the marks inside the enclosure to underestimate the peak water surface. Verifying the connection is important, especially when evaluating marks left behind by flashy events, such as marks created by strong, short-duration storms, steep terrain, or sudden releases from dam breaks or debris pileups. Occasionally, a hydrographer may discover a structure containing mud lines that are higher than outside high-water marks, indicating a sudden inflow or other rapidwater condition, discussed later in this manual.

Under certain circumstances, water containing oils from decomposed materials will form persistent clumps or lines of foam that stick to surfaces, marking the peak water elevation after the flood has receded. An example of a foam line on a bridge pier that indicates the peak height of floodwaters in that location is shown in figure 4.

Porous materials such as wood and concrete can absorb floodwater, leaving a stain line that could indicate a flood peak; however, hydrographers should be wary of capillary action that may wick the water higher than the peak water surface (fig. 5). Wicking will overestimate the high-water elevation; therefore, care should be taken to search for corroborating marks, especially marks on nearby nonporous surfaces.

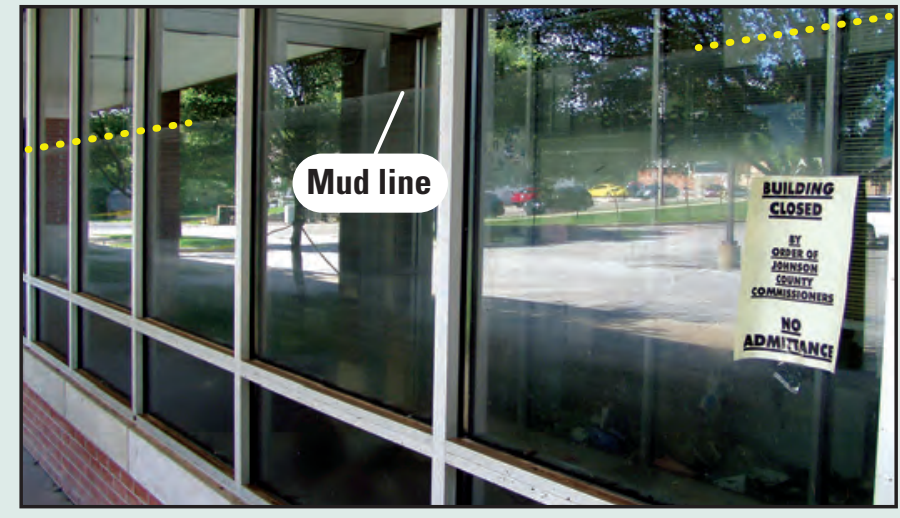

Figure 3. A well-defined mud line left on the interior side of a glass wall.

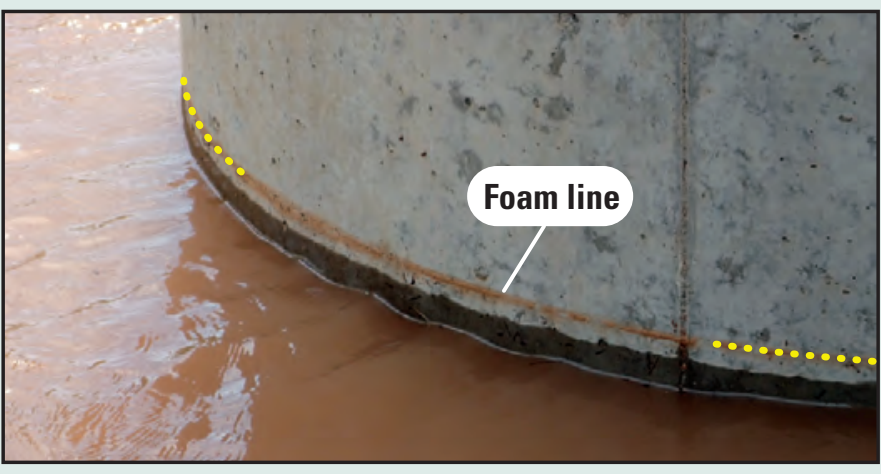

Figure 4. A foam line that was left on a bridge pier as floodwaters receded. Photograph by David C. Sasser, Jr. 


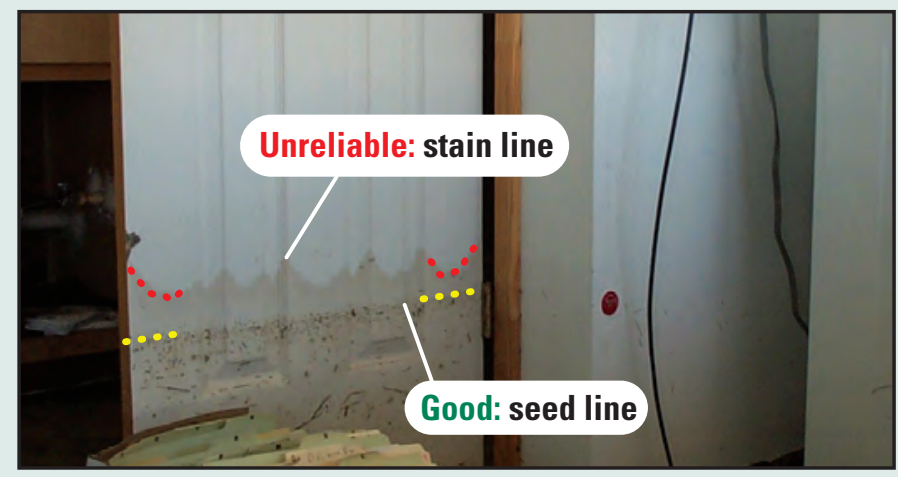

Figure 5. A stain line on a wood door that has absorbed floodwater. Note the seed line below the stain line, indicating the true high-water elevation at this location and the amount that could be overestimated because of porous material wicking.

\section{Cameron, Louisiana}

On September 24, 2005, Hurricane Rita made landfall in southwest Louisiana and southeast Texas as a Category 3 hurricane. About 4,000 square miles of Louisiana were inundated with as much as 15 feet of storm tide. Cameron, Louisiana, is near Hurricane Rita's landfall location and was subject to substantial storm tide, hurricane-force winds, and violent wave action. Before landfall, an experimental network of data loggers was deployed throughout southwest Louisiana to record the timing, extent, and magnitude of the anticipated storm tide associated with Hurricane Rita (see online report at http:// pubs.usgs.gov/ds/2006/220/). Being an experimental method, quality-assurance data (high-water marks, manual water surface elevation measurements, and real-time data) were needed to compare to the storm-tide data recorded by the data loggers.

After the storm receded, a high-water mark was identified inside the front door of the Cameron Parish courthousea location that represented a quiescent area that would not be subject to wind and wave action. The integrity of the building was evaluated to (1) assess its ability to permit storm-tide water to inundate the building at the same rate as outside (that is, hydraulic connection), and (2) ensure that the force of the storm tide did not displace the building from its original location (which would compromise the

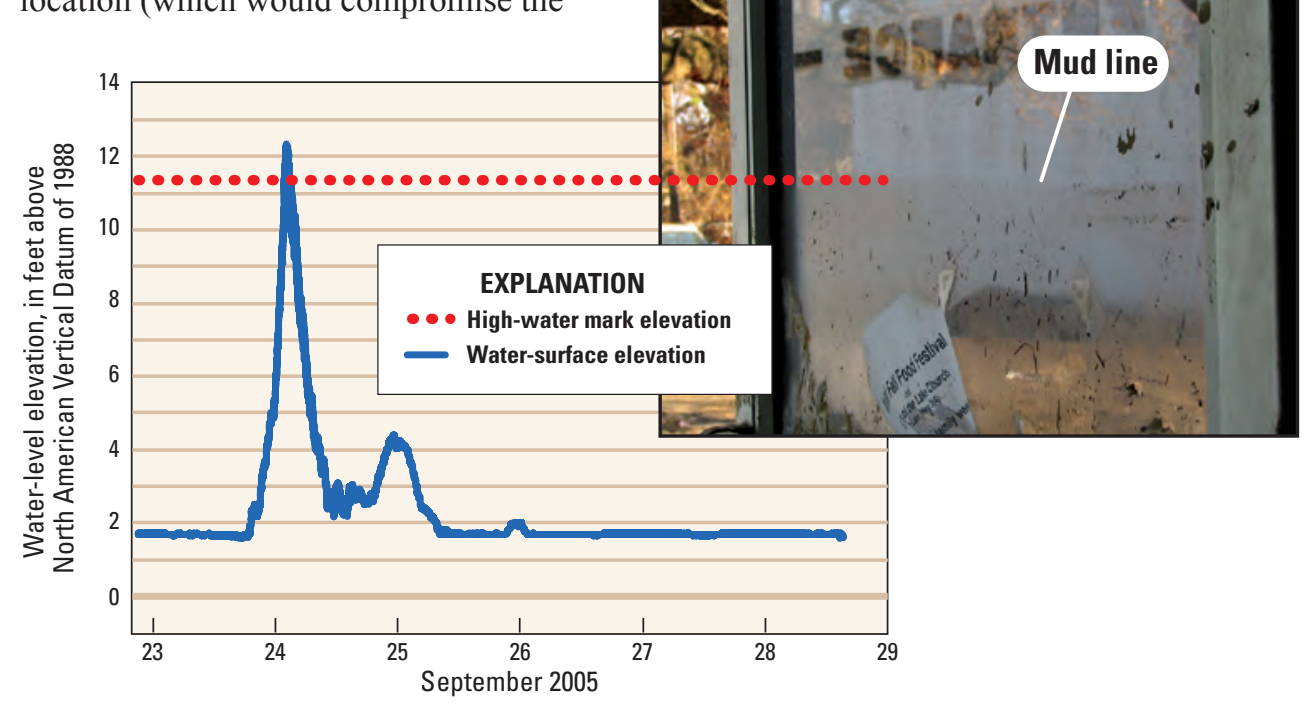

integrity of the high-water mark). The uncertainty of this high-water mark was determined to be within \pm 0.1 foot based on the type of mark (a mud line), the material on which the mark was made (glass), the environment in which the mark was created (protected, but with a hydraulic connection that was assumed to be adequate), and the nature of the hydrologic event at this location (flashy, violent, and substantial).

The storm-tide peak recorded by the data logger confirms that inundation of the building lagged behind the inundation outside the building as the elevation of the high-water mark was about 1 foot lower than the peak recorded by the data logger outside the building. The elevation difference proved that the hydraulic connection was inadequate, and this high-water mark was not reliable peak verification for the data logger.

Understanding the environment in which the highwater mark is created and the nature and timing of the hydrologic event is critical to identifying and qualifying high-water marks. 


\section{Seed Lines}

Seed lines form when fine materials float on top of tranquil water and remain on objects after the water recedes. Seed lines can be left on tree trunks, bridge piers, buildings, and other objects in the flooded reach of a stream. Exposure to sun, wind, and rain can quickly remove seeds and small materials within hours or days; therefore, seed lines should be identified and marked with more permanent methods (described in a later section) soon after the flood event.

The best seed lines are typically left inside flooded structures and enclosures (such as buildings, gage houses, and utility boxes) where the structure stilled the water, resulting in straight and well-defined lines (fig. 6). Seed lines can be more reliable than mud lines because seed lines are not prone to wicking (fig. 5). However, seed lines (and all interior high-water marks) that are identified inside of structures should be verified against outside marks to ensure a good hydraulic connection.

External faces of structures can also collect good seed lines. The photographs in figures $7 A$ and $7 B$ show typical seed lines on the outside of two structures. Note that the window screen in figure $7 B$ collected a much higher-quality seed line than the siding surrounding the window.
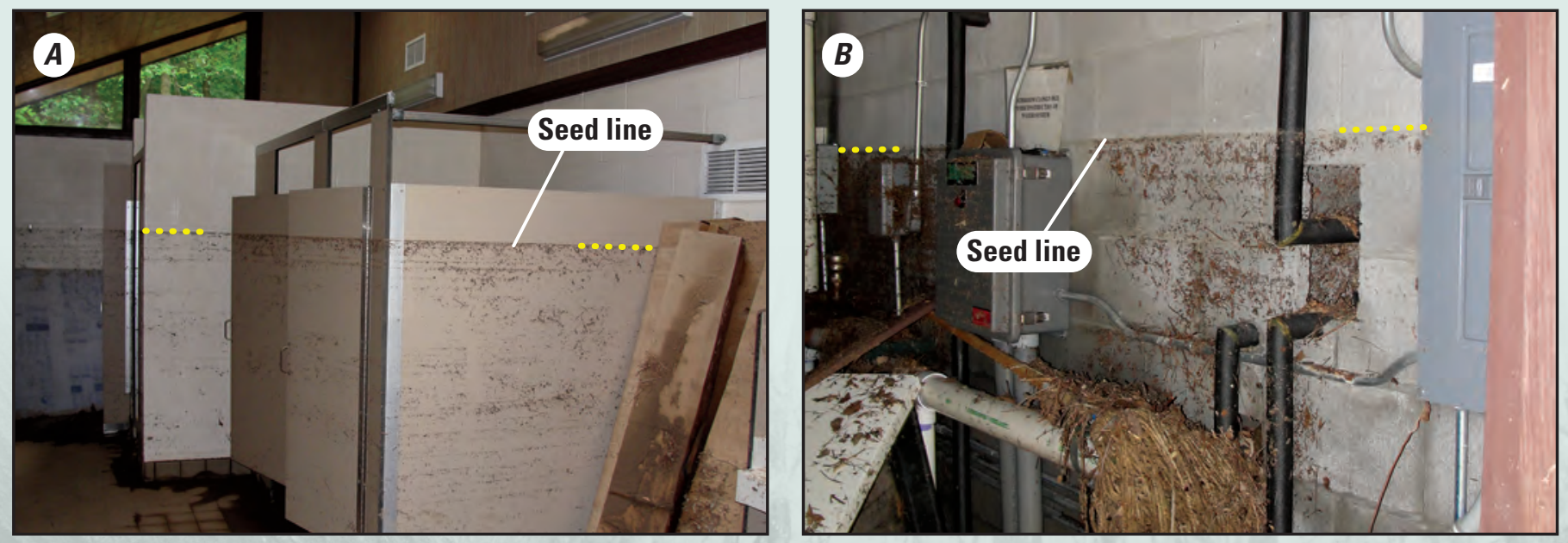

Figure 6. Seed lines on the inner surfaces of $A$, a restroom and $B$, a utility room. Photographs by Walter Killion. 

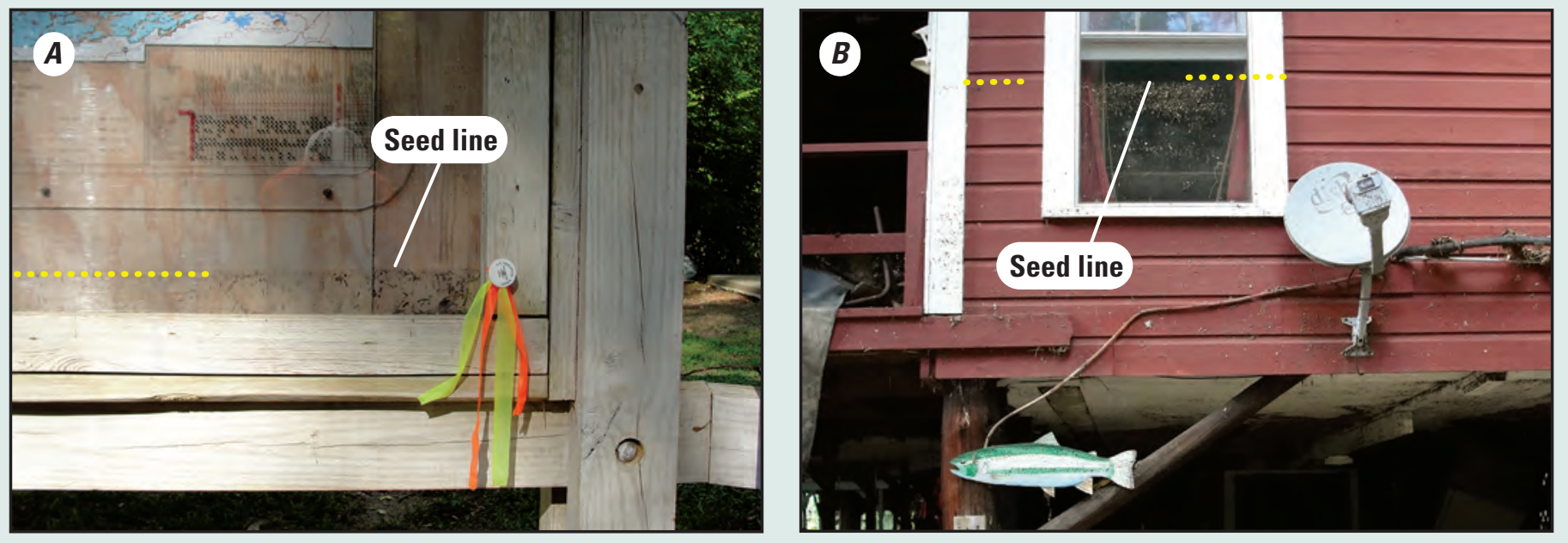

Figure 7. Seed lines on the surfaces of $A$, a recreational sign and $B$, a home exterior. Photographs by Walter Killion.
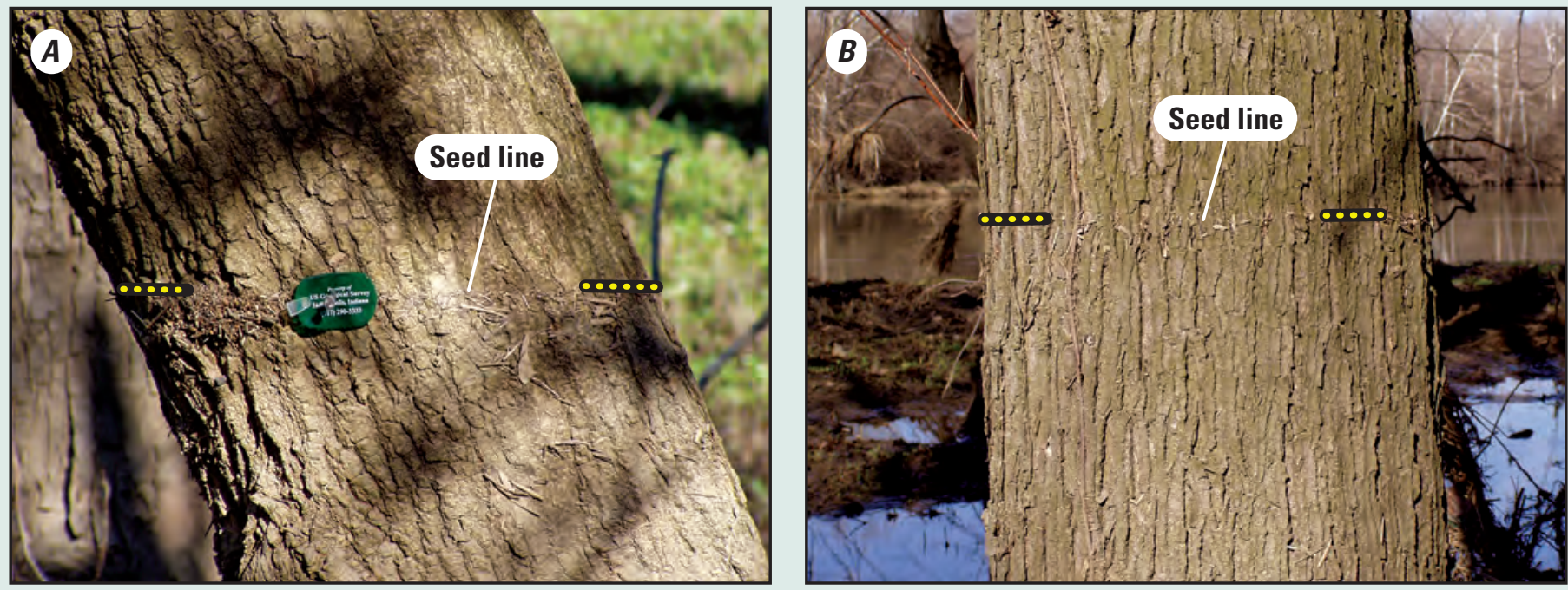

Figure 8. Well-defined seed lines on large tree trunks $(A, B$, and $C)$. Photographs $A$ and $B$ by Bret Robinson; photograph $C$ by R. Russell Lotspeich.
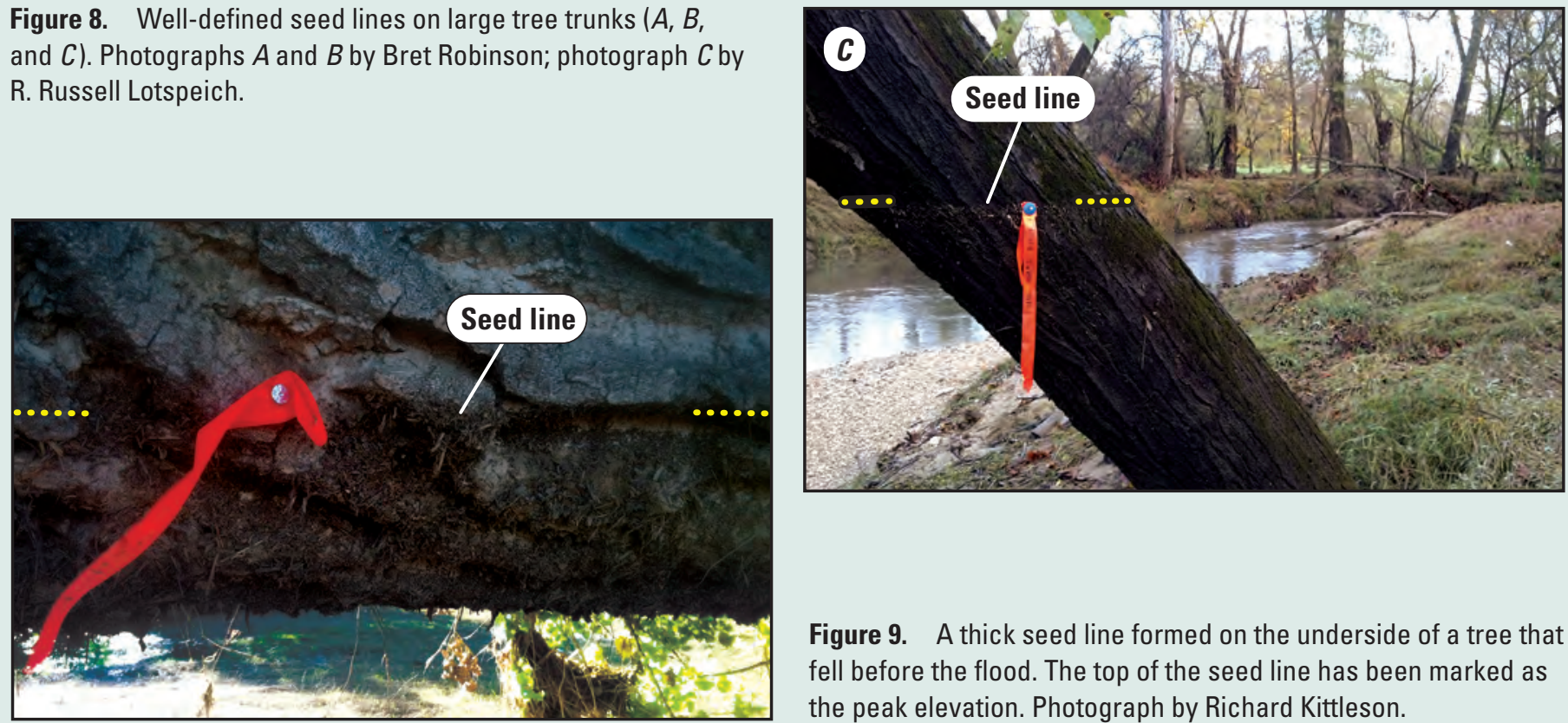

Figure 9. A thick seed line formed on the underside of a tree that fell before the flood. The top of the seed line has been marked as the peak elevation. Photograph by Richard Kittleson. 


\section{Debris Lines}

Debris lines are trails of twigs, grasses, and other small debris left on sloping ground at the edge of a river where calmer water, as it receded, deposited the material (fig. 10). Generally, debris lines are not as reliable as seed lines because debris lines have a coarser texture and have a tendency to sag as the water recedes. However, debris lines sometimes form the only available high-water marks for a given reach, especially in reaches with less woody vegetation or other obstructions. Debris lines form primarily in tranquil overbank areas and flood plains; however, flooded streams with swift-moving main channels may still collect debris lines at the edges where velocities may be lower or eddies concentrate the floating debris. The best debris lines form in slack water areas where an obstruction, a backwater tributary, or a change in channel geometry created a tranquil pool. A new debris line forming in a small pool, immediately following the peak of a flood event, is shown in figure 11.
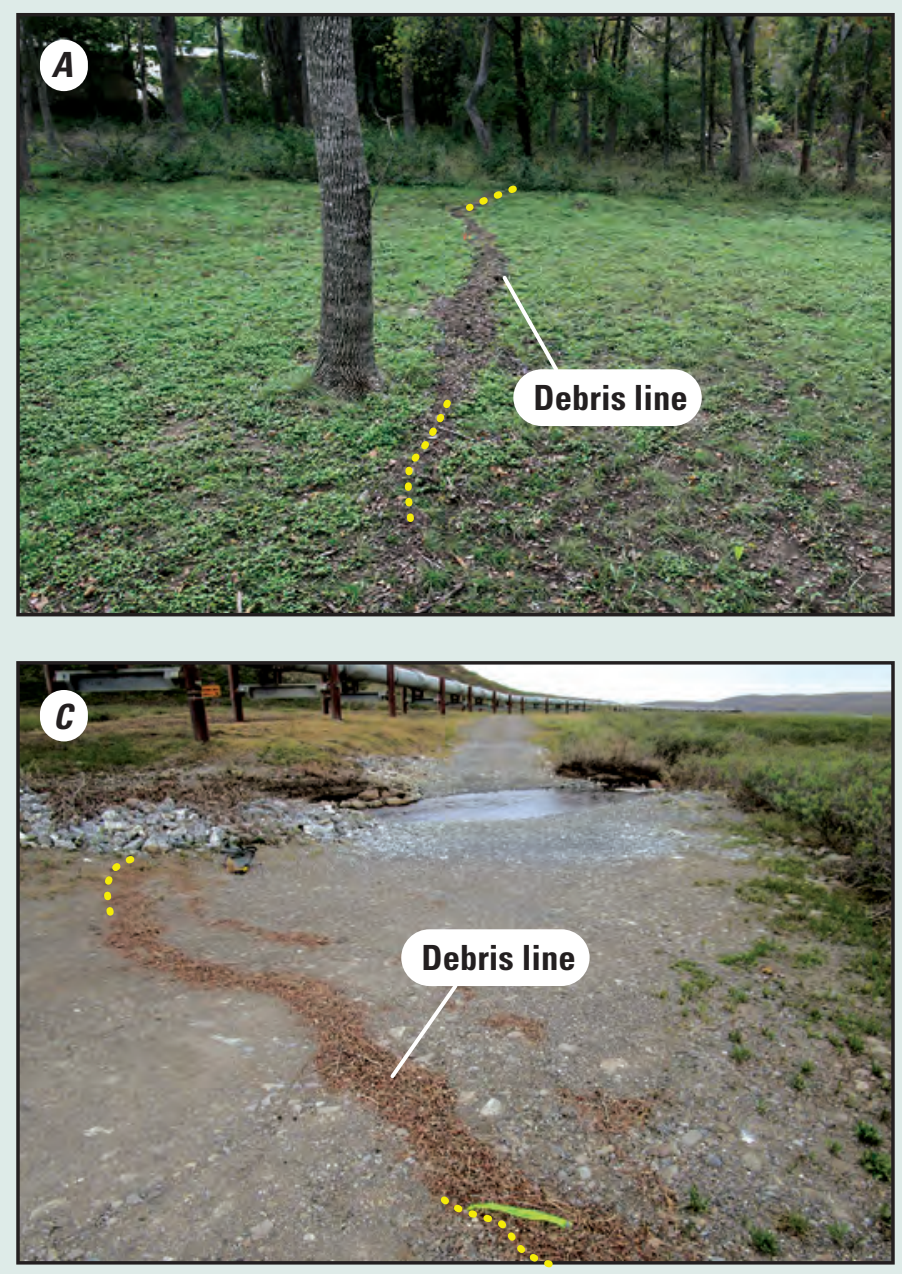

If a considerable amount of debris has collected, a measurable elevation difference is possible between the landward and streamward edges of the debris line. In nearly all cases, the landward side of the debris trail most closely reflects the high-water boundary, as shown in figure 12. On steeper bank slopes, the high-water mark may be slightly higher than the landward edge of a debris line, which settled as the water receded. Look closely for seed lines or an accumulation of finer particles just above the landward side of the debris line. The finer particles may give the most accurate indication of the peak water surface. Additionally, check for matching debris lines on opposite banks of a channel; a mismatch may be caused by complex flow patterns or by natural or human disturbance. Surveying many debris line marks on both sides of the channel can help identify errant marks.

Hydrographers should give more preference to debris lines on mildly sloping banks than to debris lines on steeply sloping banks because gravity has more effect on the placement and movement of debris materials on steeper slopes. Rain, wind, or human interference such as recent mowing or cleanup activities should also be considered when judging the quality of a debris line.
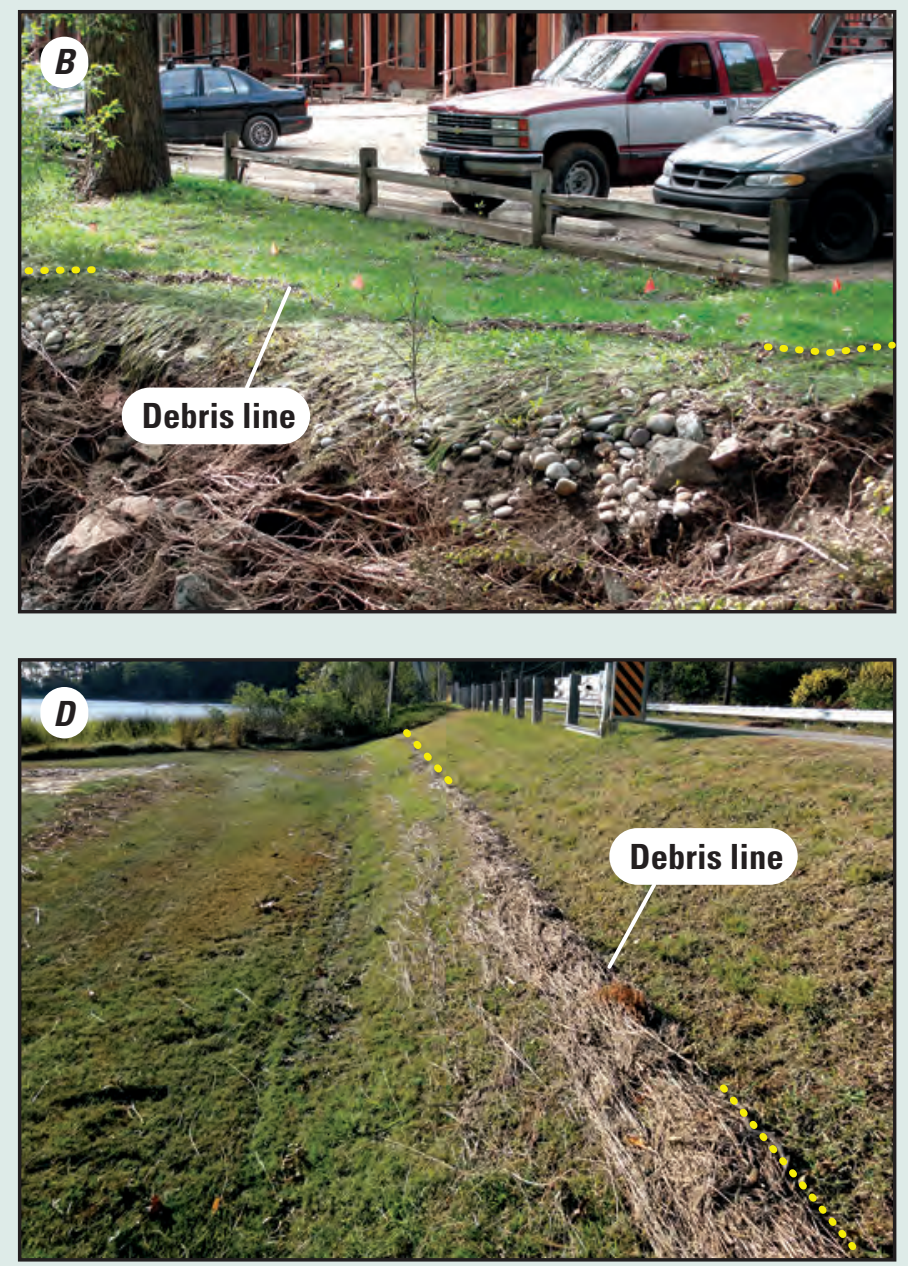

Figure 10. Debris lines formed on $A$ and $B$, grassy overbanks; $C$, a roadway; and $D$, a grassy highway embankment. Photograph $C$ by Michelle Kang; photograph $D$ by R. Russell Lotspeich. 

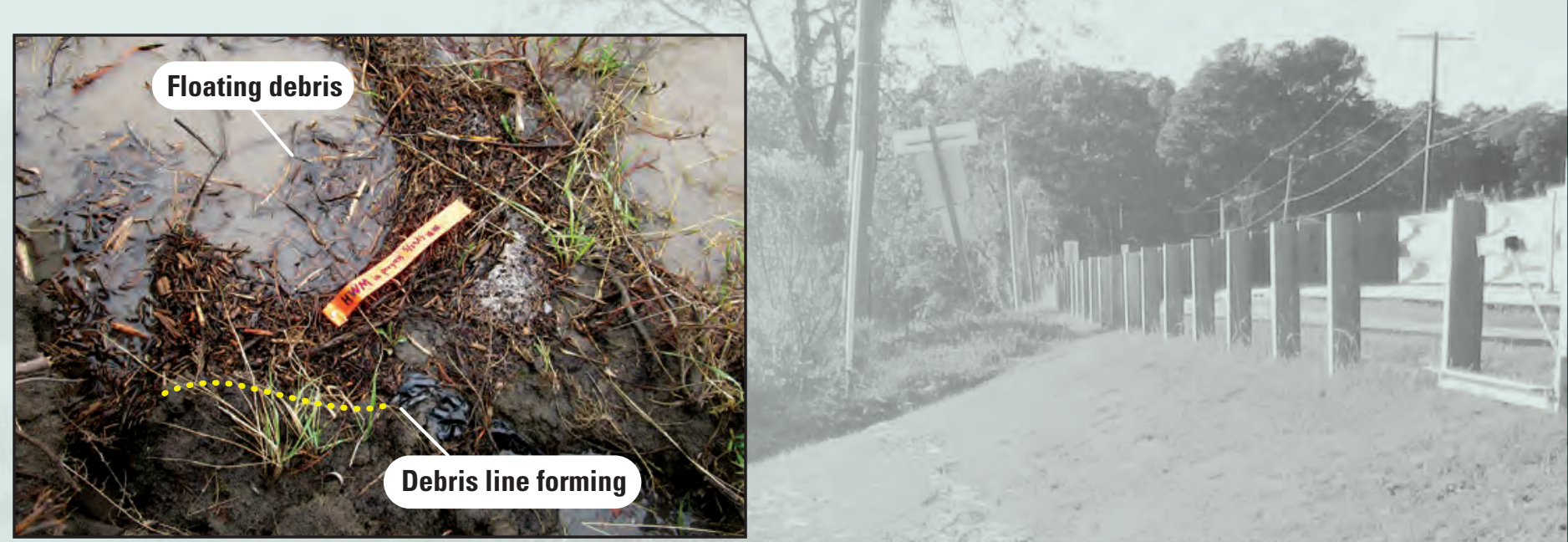

Figure 11. Floating debris as it collects into a small debris line as floodwaters recede. This high-water mark was photographed during the peak of the flood. Photograph by Michelle Kang.

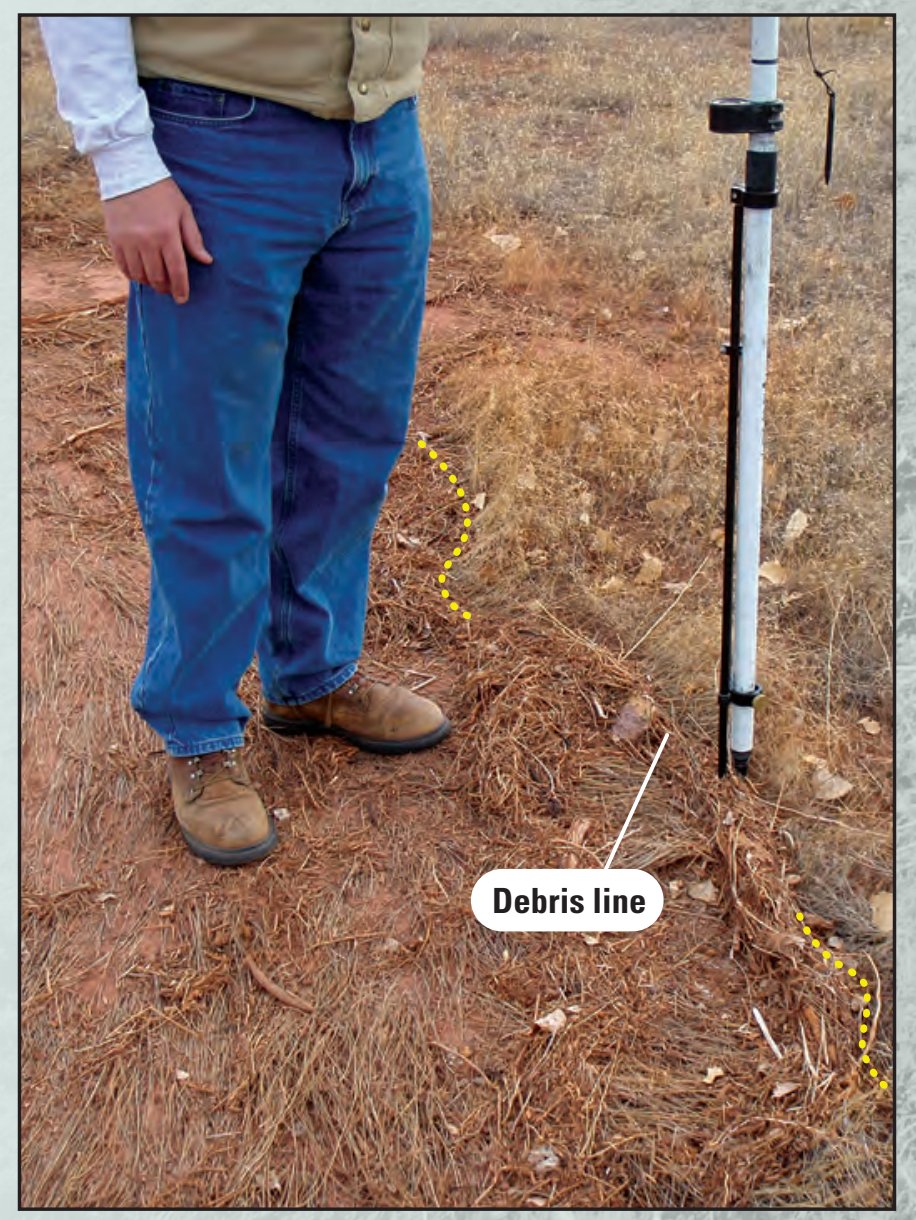

Figure 12. A hydrographer surveying the landward edge of a debris line. Photograph by Christopher Wilkowske. 


\section{Ice Rings}

When floods recede during freezing periods, ice sheets may form at the water surface. As the under-surface water recedes, suspended plates of ice, referred to as ice rings, may be left behind around cold objects such as fence posts or vegetation (fig. 13). If sunlight or increased temperatures have begun to melt the ice or if additional frozen precipitation has added thickness to the ice, the indicated water surface will be uncertain. More importantly, determining whether the freeze

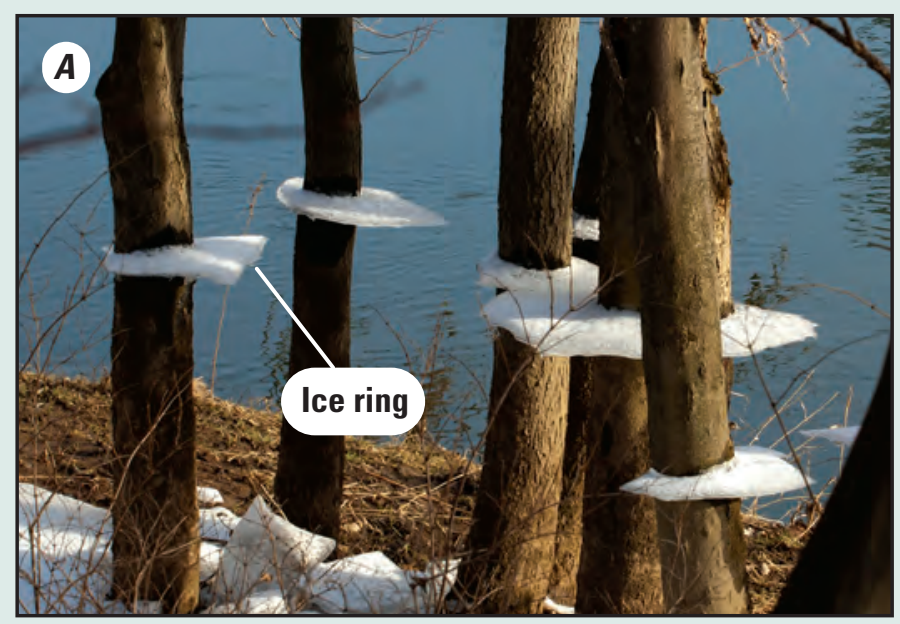

Figure 13. $\quad A$, Ice rings formed around trees; $B$, ice rings formed around a fence post caused by multiple freezes and thaws; and $C$, delicate ice rings preserved in shoreline grasses. Photograph $A$ by Pat Coate; photographs $B$ and $C$ by Jarvis Kaderlik. happened at the peak of the flood or at a lower water surface elevation during the recession is difficult. A somewhat unusual circumstance of hanging limbs that were originally frozen into surface ice and then released by the thawing river is shown in figure 14. Because their position at the time of initial freezing is unknown, establishing an accurate high-water mark from these ice-ring remnants alone would be difficult. As always, careful evaluation and verification with other marks are necessary.
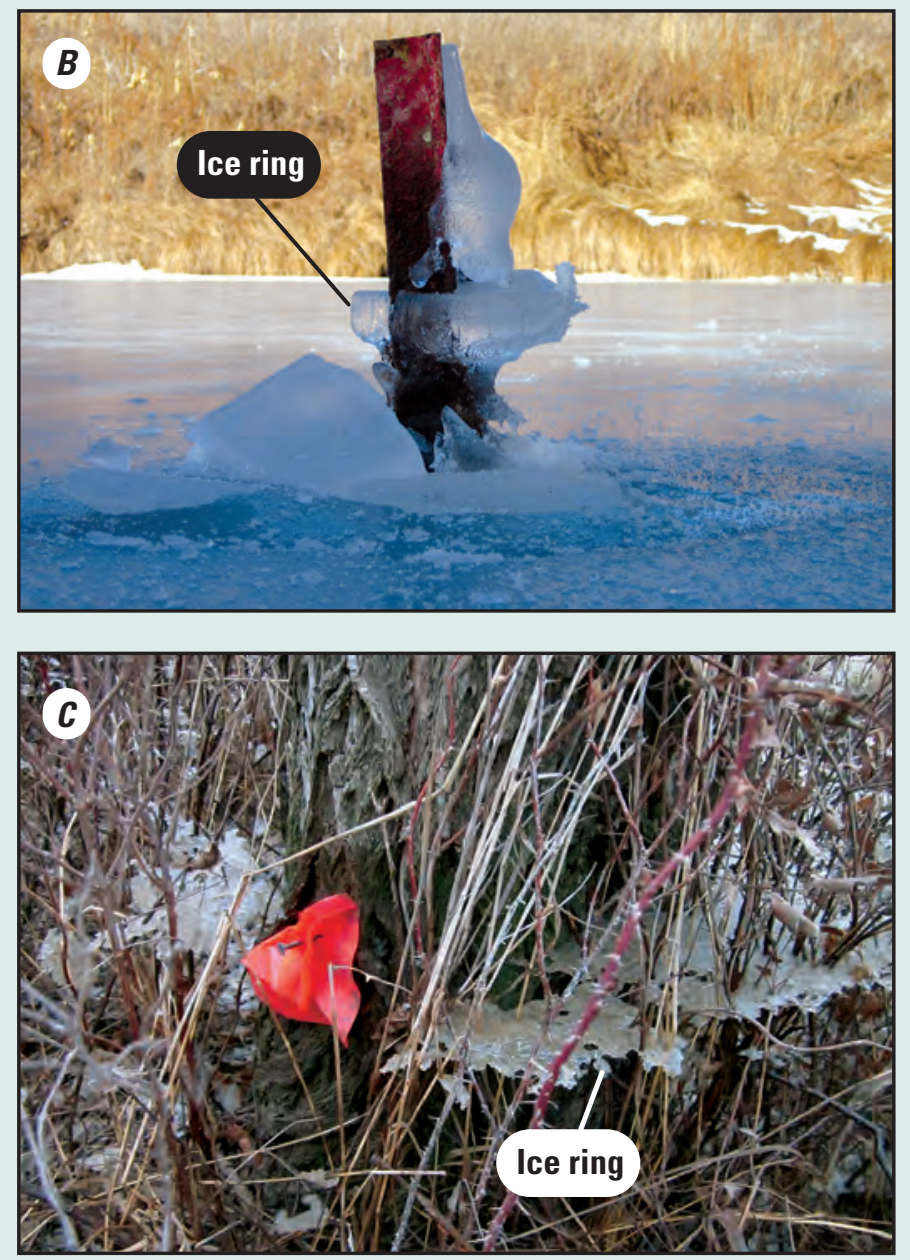

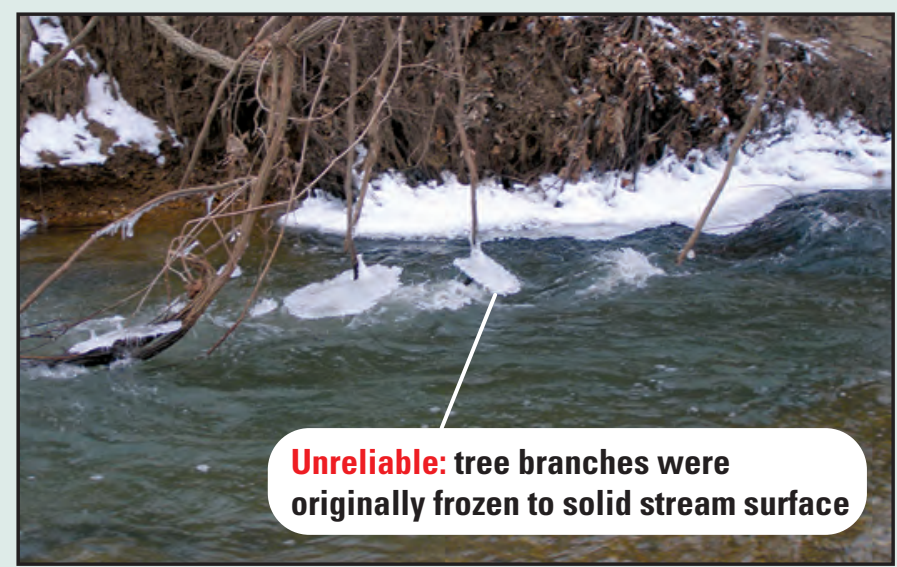

Figure 14. Ice rings on

hanging limbs above a fast flowing stream. These ice rings, originally frozen to a solid stream surface then released when the stream thawed, make for uncertain high-water marks. 


\section{Rapid-Water High-Water Marks}

In higher-velocity stream reaches, water often transports higher sediment loads and leaves behind high-water marks that are characteristic of high-energy flows. Rapid-water high-water marks often come with greater uncertainty because of wave action and runup on flow obstructions; however, rapid-water high-water marks may represent the best available evidence for many flood peaks and form an important class of high-water marks. 


\section{Cut Lines}

When the flow of water erodes a stream bank, a rapidwater high-water mark called a cut line or scour line can form (fig. 15). Wave intensity, angular velocity, and bank material properties dictate the quality of the water surface elevation determined from a cut line. Where wave action or post-flood soil slumping is suspected, the high-water mark elevations will have more variation; therefore, collecting a greater number of high-water marks will help estimate an average water surface elevation. Viewing the complete set of cut lines from the opposite bank can provide context and reveal the best line. Because cut lines tend to form on outside banks where streams curve and water velocities are higher, the cut lines may trace superelevated water surfaces, depending on the stream slope, water velocity, and radius of the bend. The high-water marks presented on the outside of the bend by a superelevated water surface will be higher than the marks on the inside of the bend.

In cold climates, snow-covered stream banks may also reveal cut lines in snowpack that has melted along a line of contact with floodwaters (fig. 16). These cut lines must be treated with strong skepticism. Floods often happen during spring melting when, after a flood, the snow's edge may continue to melt and withdraw farther than the actual edge of the flood, producing an overestimated flood peak. Alternatively, on steeper slopes, gravity may cause sagging or slumping of the soil or snow along a cut line, leaving an underestimated flood peak.

Winter conditions may also produce a cut line created by floating ice, which can carve scour lines in trees and other obstructions during a thaw. Hydrographers must consider how the thickness of the ice may affect the uncertainty of the mark. In all cases, hydrographers should carefully examine cut lines in cold and warm conditions.
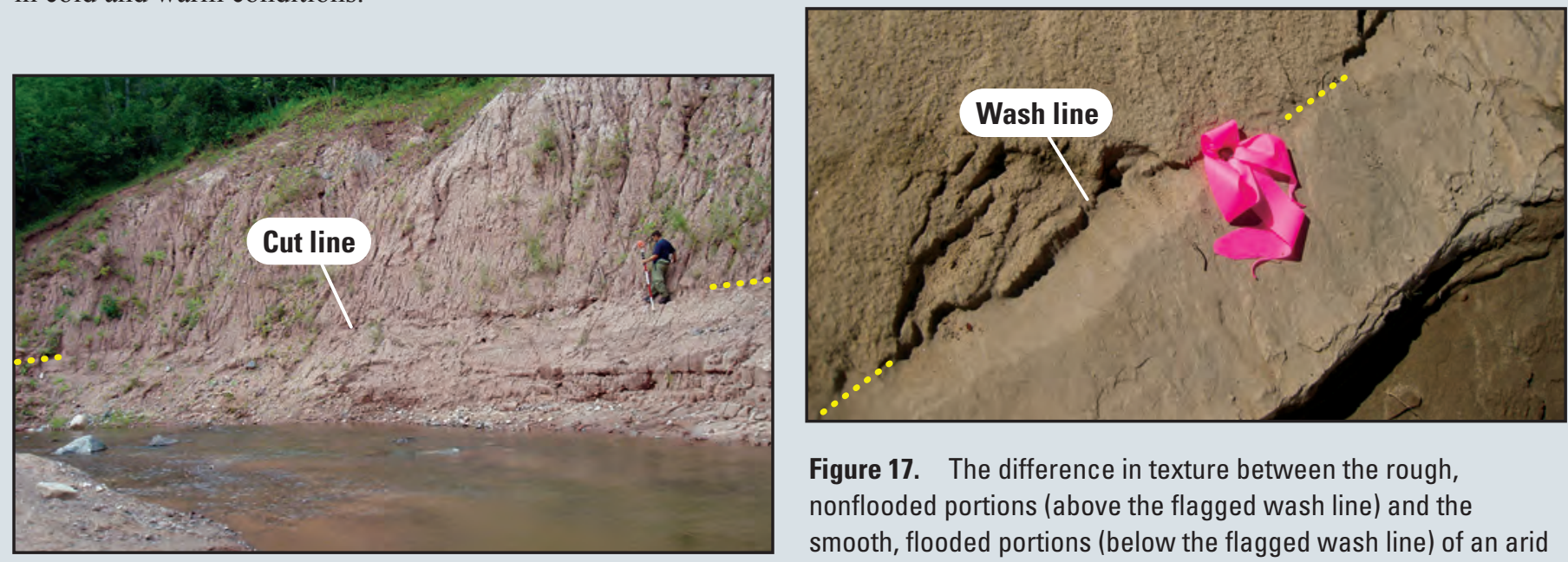

Figure 17. The difference in texture between the rough, nonflooded portions (above the flagged wash line) and the smooth, flooded portions (below the flagged wash line) of an arid

Figure 15. A hydrographer preparing to survey a cut line in a sand/clay bluff. 


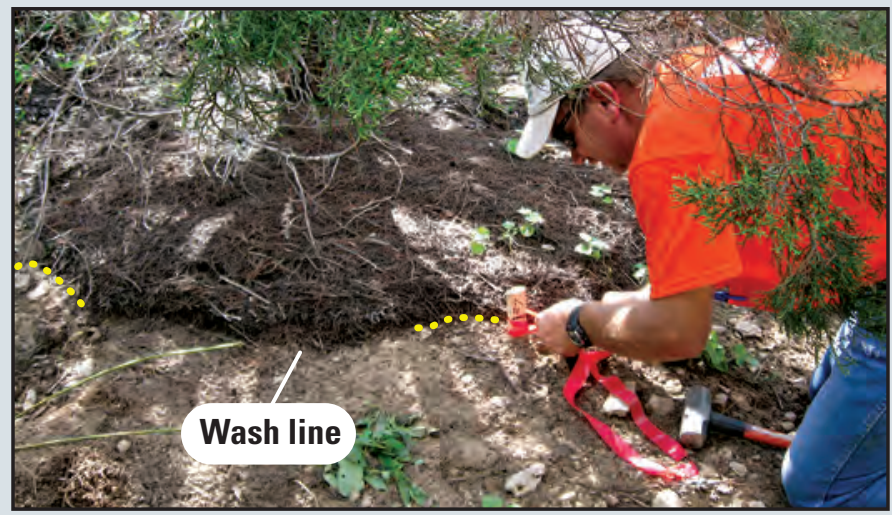

Figure 18. A hydrographer flagging a wash line that was created when floodwaters removed a thick bed of needles revealing the soil underneath. Photograph by Karl Winters.

Another type of wash line is created when swift floodwater folds grasses down as the water flows over them, leaving nearby nonflooded grasses still standing. The bends in the grasses indicate the direction of flow, and the line between bent and unbent grasses indicates the extent of flooding (fig. 19). Folded grasses can also exhibit a concurrent mud/silt line (discussed in the "Mud Lines" section), or the grasses may lose their green coloring as a result of being submerged for an extended period. The flood peak is indicated by the most landward extent of the dividing line between the areas of folded grasses and the areas of standing grasses.

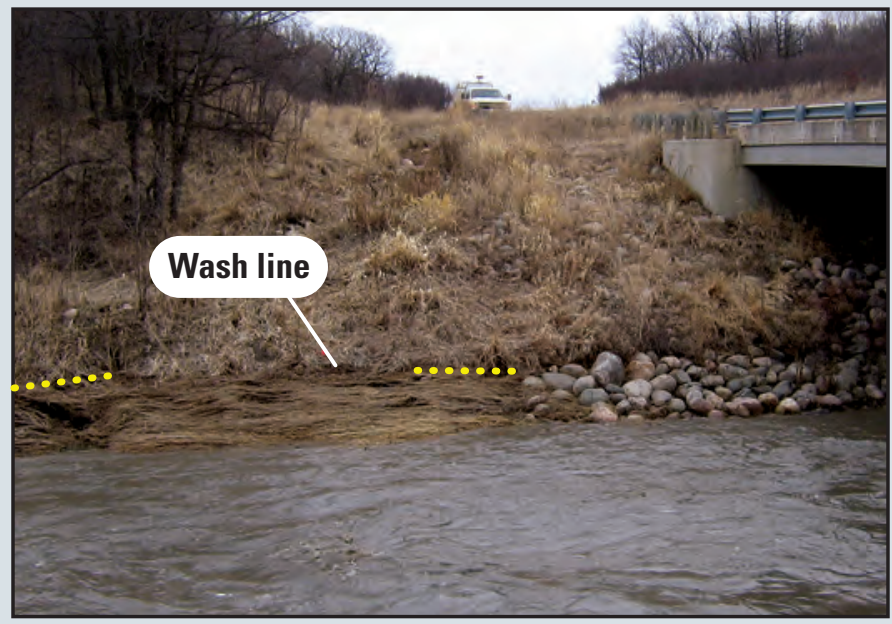

Figure 19. A folded-grass wash line, marked by the boundary between grasses that were bent by floodwaters and grasses that were not flooded. Photograph by Nathan Stroh.
The more common (but less obvious) wash line in figure 20 demonstrates how green standing vegetation near yellowed bent grasses may be partially obscured by new growth that has already sprouted among the bent grasses. The area beneath the feet of the hydrographer in figure 12 also indicates a bentgrass wash line, but the concurrent debris line at the edge of the washed area better defines the edge of the water.

Wash lines can quickly disappear as natural processes return the surface to its previous state. Timeliness is critical in identifying and flagging washed areas before new loose material reoccupies bare spaces or new growth replaces bent and yellowed grasses. As with cut lines, a hydrographer may have better success seeing the true elevation of wash lines by standing back from the bank to gain a wider view.

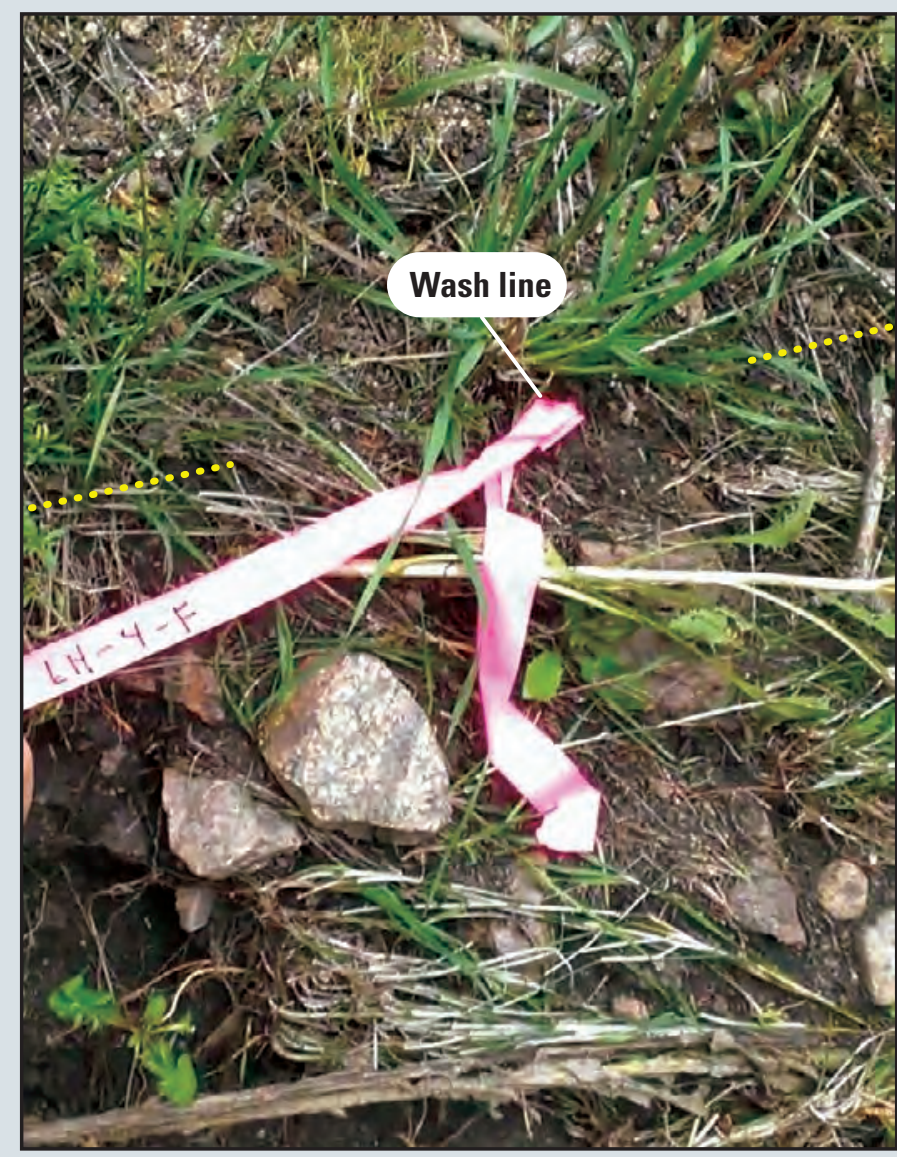

Figure 20. A wash line obscured by new growth. Note the lack of any bent, yellowed grasses above the mark compared to a significant amount of bending and yellowing below the mark. 


\section{Mud Lines}

Mud lines deposited by slow-moving water were discussed earlier, but mud lines can also be deposited by fastmoving water; in fact, water at higher velocities will transport more available sediment downstream. If the upstream sediment contains sufficiently different materials than the downstream bed material, a flooded river can paint a layer on the land surface with a distinct border of differing colors or textures, or both. An example from northern Arizona, where mud lines are common after flood events, is shown in figure 21.

Mud line identification presents several pitfalls that can be avoided with proper awareness. The "Paria River, Arizona" narrative illustrates some of these pitfalls. High-velocity, high-sediment-load rivers can paint lines on structures such as bridge piers; however, the lines may generate misleading highwater marks because of waves, pileup, and drawdown generated by the structures themselves (fig. 22 ). Hydrographers should note the variability in mud-line elevations on a large structure, especially in the upstream to downstream direction, before determining if the mud lines should be used as high-water marks. If highly-variable mud lines must be used, recording the measured amount of variability is important, as described in the Evaluation section of this manual. For smaller obstructions where runup is evident on the upstream side and drawdown is evident on the downstream side, a mark can be assumed halfway between the two extremes.

As with wash lines, care should be taken with mud lines to watch for receding soil saturation that may masquerade as mud lines and underestimate the actual peak water surface. Finally, hydrographers should be acquainted with the differences between flood flows and debris flows, and the evidence that each leaves behind. Mud lines formed in thick layers with embedded, random-sized rocks and vegetative debris may be caused by debris flows. Debris flows must be treated differently because they do not have the same fluid characteristics as flood flows for the purposes of indirect streamflow measurement. This topic is further discussed in the Pierson (2005) fact sheet listed in the references of this report.

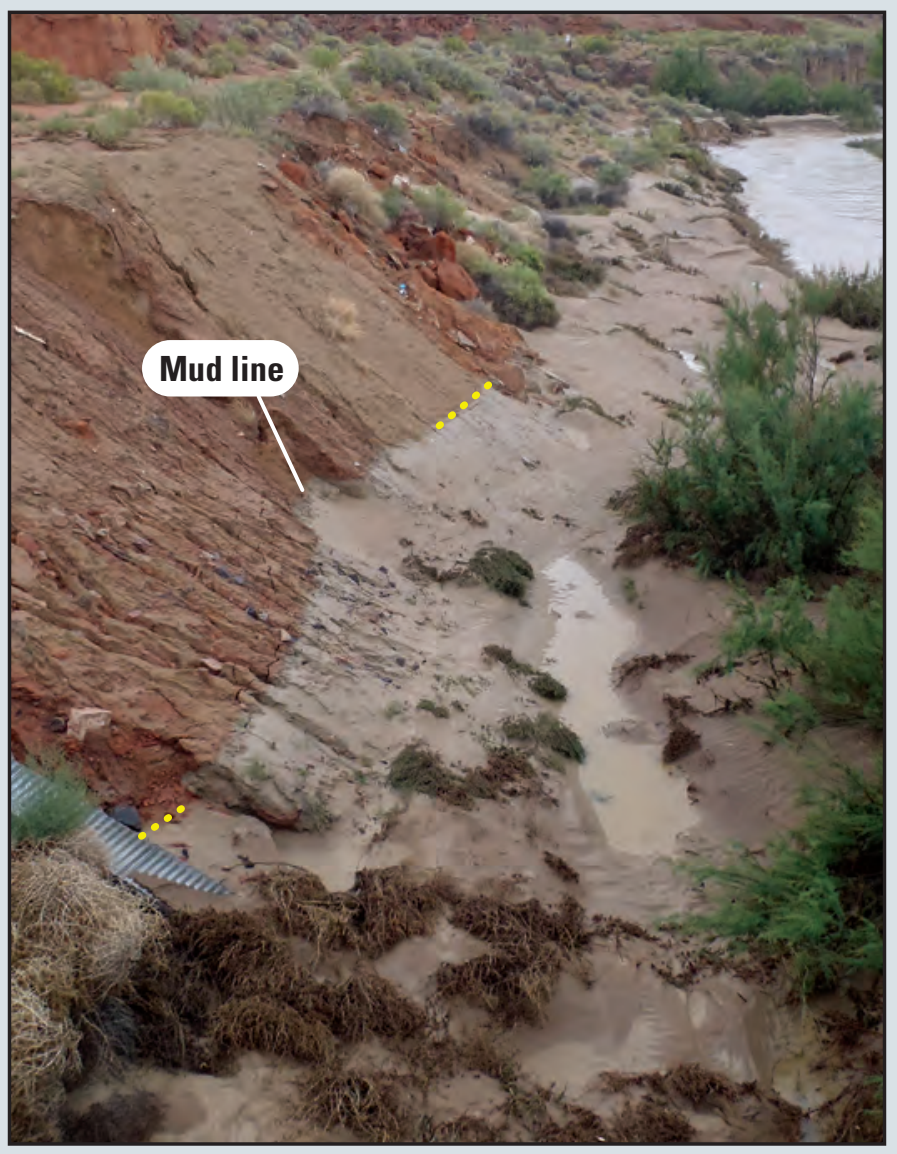

Figure 21. A rapid-water mud line of a different color than the existing bed sediment. Photograph by Jon Mason.

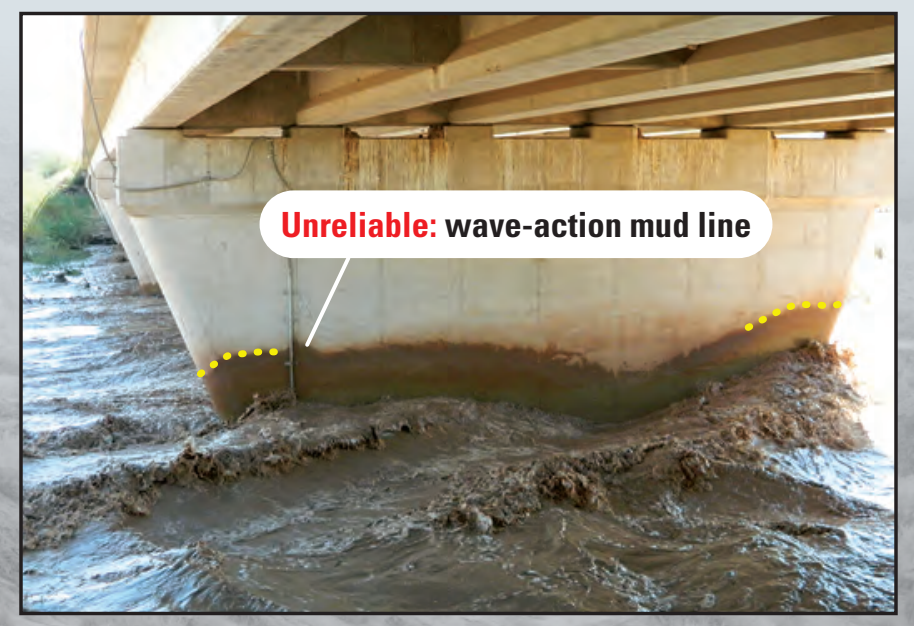

Figure 22. Unreliable mud lines created by wave action on a bridge pier. Photograph by Emmet McGuire. 


\section{Paria River, Arizona}

The Paria River is a high-gradient, sediment-rich stream that has an annual streamflow record that is important to sediment management operations in the Grand Canyon. Flows are extremely flashy with high velocities, making direct measurements and streamgaging difficult. Difficult measurement conditions are compounded by a dynamic channel geometry that experiences scouring and filling during many runoff events. Indirect streamflow measurements are commonly used along the Paria River to augment the gaging record and are instrumental to the annual record of this stream.

High-water marks are generally easy to find along the Paria River and at other sites in northern Arizona where sediment loads are high. Entrained sediment often deposits consistent mud lines throughout the reach that are a slightly different hue than the soils around the streamgage, making post-flood high-water marks easy to distinguish. However, the highenergy flows of the Paria River can artificially raise or lower high-water marks in this reach. Standing waves, migrating dunes, and turbulent surging can create conflicting high-water marks. These nuances need to be recognized while flagging so that erroneous marks can be avoided during surveying.
Hydrographers visiting the Paria River use a few strategies to ensure that the most representative high-water marks are identified. First, crews arrive as soon as possible after an event while mud lines are fresh. Once dry, mud lines can slowly fade and be more difficult to visualize. Second, hydrographers stand on the banks and look for high-water mark evidence on the opposite banks from a distance. Using line of sight and a hand level, a hydrographer can generally visualize a consistent water surface profile and avoid outlying high-water marks that may have been caused by secondary disturbances.

On September 28, 2014, this section of the Paria River displayed a phenomenon that made high-water mark identification more complicated. A slight left-hand bend in the stream superelevated the water surface along the right bank, consistently creating high-water marks with higher elevations than those on the left bank. To estimate the real water surface, both left and right bank high-water marks were flagged and surveyed, and the final water surface was interpreted using an average of the two sets of marks.

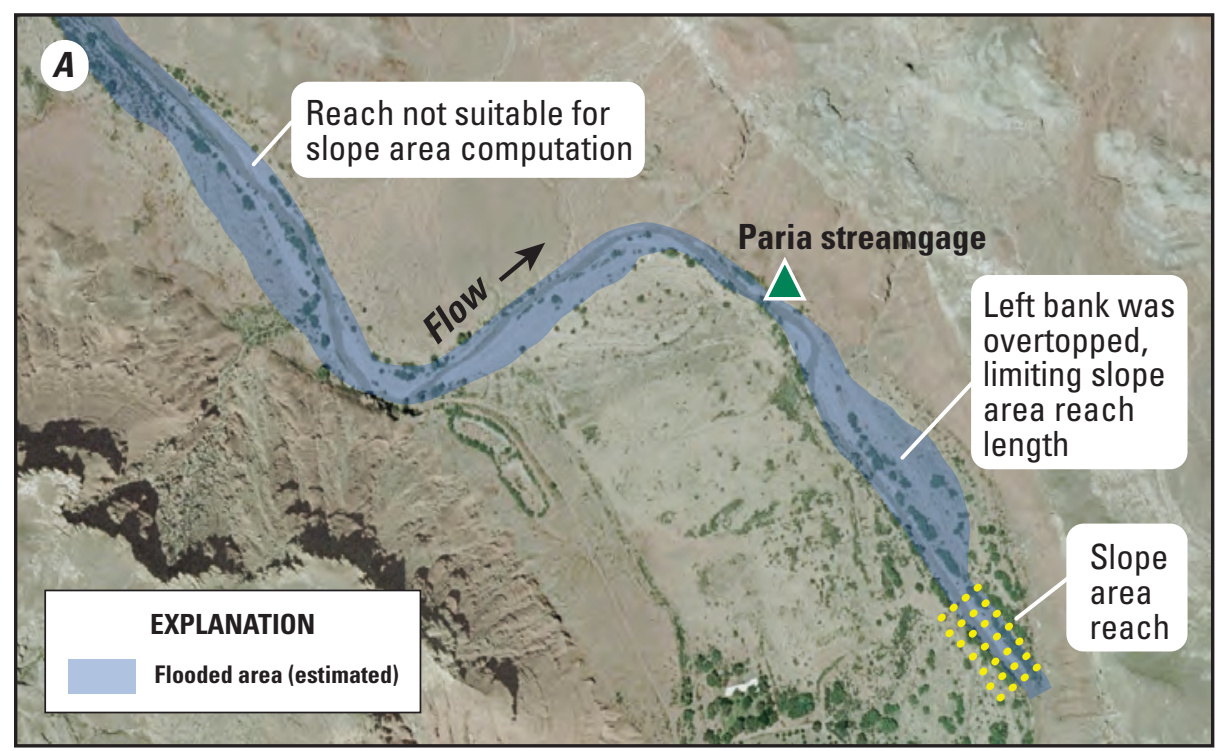

Map, photograph, and graph showing $A$, the reach surrounding the Paria River at Lees Ferry, Arizona (station number 09382000; http://dx.doi.org/10.5066/ F7P55KJN). The entire reach was evaluated to determine the best location for indirect streamflow measurement location and the lower portion was identified as the best location; $B$, mud lines of deposited sediment of a lighter color than the existing soil; and $C$, highwater marks (HWM) collected on the right $(\mathrm{RH})$ and left $(\mathrm{LH})$ banks of the Paria River after the Sept. 28, 2014, flood event. The dotted line indicates the average water surface that accounts for the superelevated high-water marks on the right bank.
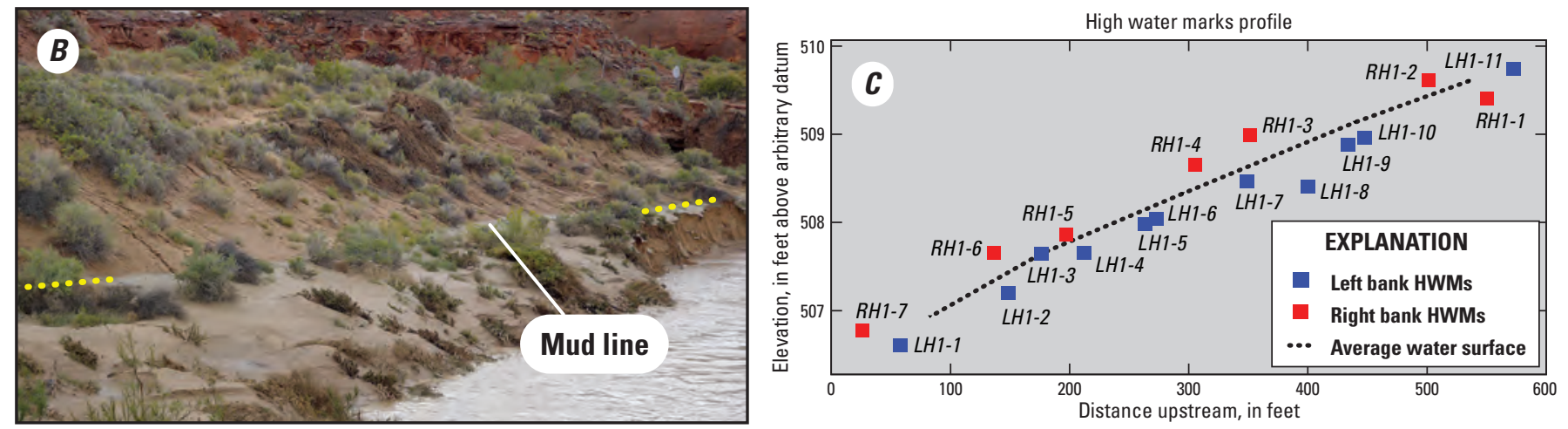


\section{Debris Snags}

Debris snags (sometimes called "trash snags" or "flood trash" in urban settings) are formed when coarse debris collects on an obstruction in the water, such as a structure, pole, fence, guy wire, tree, boulder, or bush (fig. 23). Note that some piles may be taller than others, leading to a large amount of uncertainty regarding the actual peak water surface. Large pileups can result from deposition of new materials at different stages as the water recedes. Conversely, the pileups may also result from swift flow forcing new material on top of older material. When swift flow encounters obstructions, water may run up higher on the upstream side of the object and drawdown lower on the downstream side, as shown in figure 24. This can also cause coarse debris to pile up higher than the flood peak surface, so these piles should be assigned a suitably large uncertainty or remain unused.

Thinner obstructions in slower flows may create more consistent lines of debris, such as the fence shown in figure 25; however, swift flows transporting heavy debris can cause large pileups, even on the thinnest obstructions, as seen on the utility pole cable in figure 23 . Experience and judgment must be used to decide if a useful high-water mark can be determined from large pileups. In situations where the uncertainty of a debris snag is too high to be usable, the debris snag may lead the hydrographer to the vicinity of more reliable marks, as discussed in the "Salcha River, Alaska" narrative.

If the flow obstruction is pliable, such as a small tree or thin stem, the obstruction may collect debris while bent by the force of the water (fig. 26) and then stand back up when the water recedes. This bending leads to greater uncertainty because the position in which the obstruction actually collected the debris is difficult to determine, and the observed height of the debris may be higher than the true peak water surface elevation (fig 27).

Conversely, debris caught on a hanging vine or branch may underestimate the true flood peak (fig. 26). As floodwaters bend the hanging obstruction downstream, debris collects on the portion still touching the water surface. When the water later recedes, the hanging obstruction returns to its
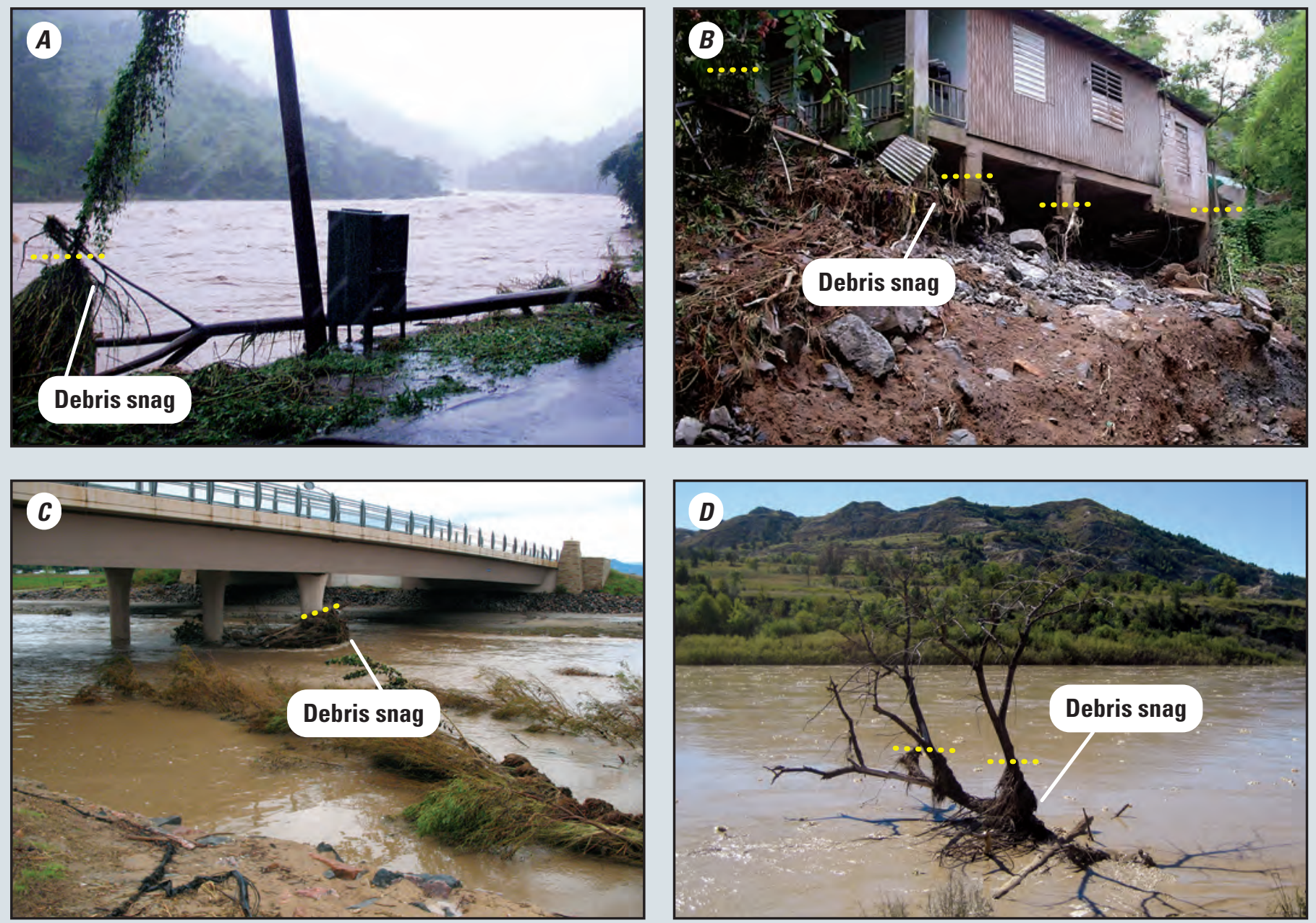

Figure 23. Debris snags on $A$, a utility pole cable; $B$, house supports; $C$, a bridge pier; and $D$, a partially submerged tree. Photograph $C$ by Toby Minear; photograph $D$ by Brent Hanson. 
original vertical position, arcing the debris snag to a lower position. This lower position likely represents a lower elevation than the actual flood elevation. In addition, the force of the water or weight of the debris can pull a hanging vine lower than its original position, further under-estimating the actual flood elevation.

The size of the materials, the position of the collecting obstruction, and the likely flow conditions must all be considered when determining a high-water elevation. Comparisons with nearby high-water marks are especially important when evaluating debris snags because of the high degree of uncertainty inherent in the processes that form most of them. Additional marks of another type are commonly needed to corroborate debris snags.

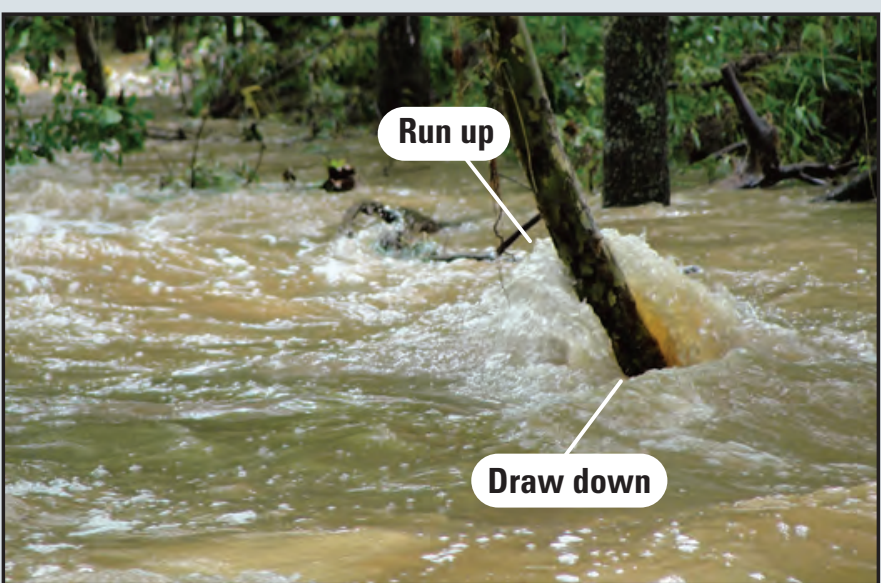

Figure 24. Significant runup and drawdown caused by swift flows around a tree.

\section{Salcha River, Alaska}

On June 20, 2014, regional heavy summer rainfall resulted in elevated Salcha River levels. The crest-stage gage (see the "Crest-Stage Gages" section) was overtopped by the flood and could not be used to verify the maximum water level recorded by the streamgage; therefore, highwater marks were utilized to verify peak flow.

Survey crews arrived on site the day after the storm (June 21) and began documenting the high-water marks, noting the location, the type, and the quality of each highwater mark. The most obvious evidence of high water was several large debris piles near the gage; however, large debris piles form high-water marks with large uncertainty because of velocity pile up and the erratic movement of large debris. Crews identified a good seed line, which was

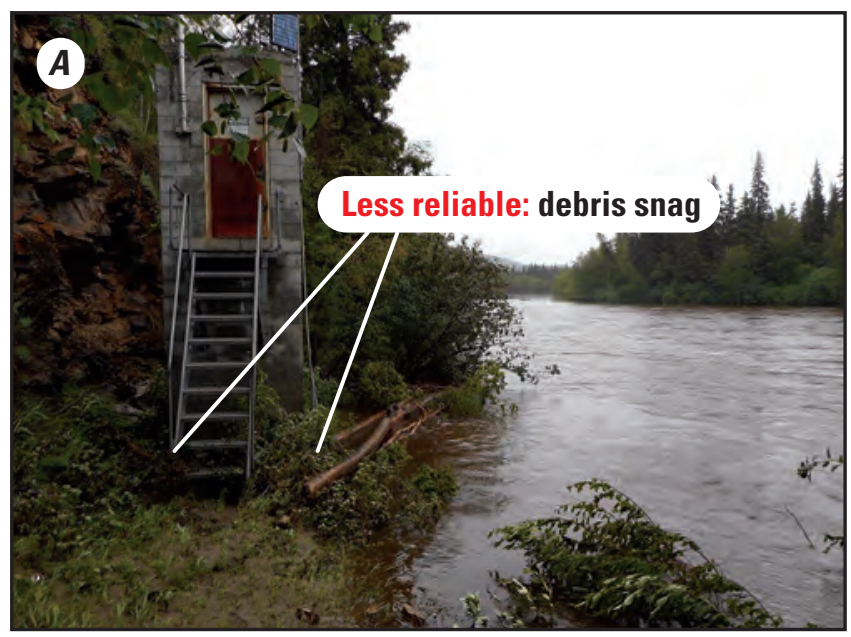

a more precise high-water mark, on the rock cliff about 10 feet shoreward of the gage house. The seed line was deposited on the downstream edge of the rock in a sheltered area not

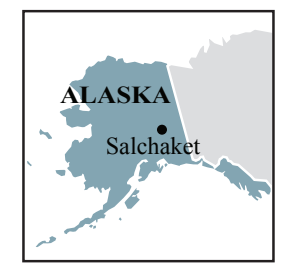
directly impacted by the current of the river. The band of needles forming the seed line was approximately 0.2 foot thick, with the highest portion of the line representing the maximum water level. Marks of this nature tend to be short lived because as the marks dry, the needles may fall from the structure on which they were left or may wash away in a subsequent rain storm. In just a few days, the seed line at this site was gone.

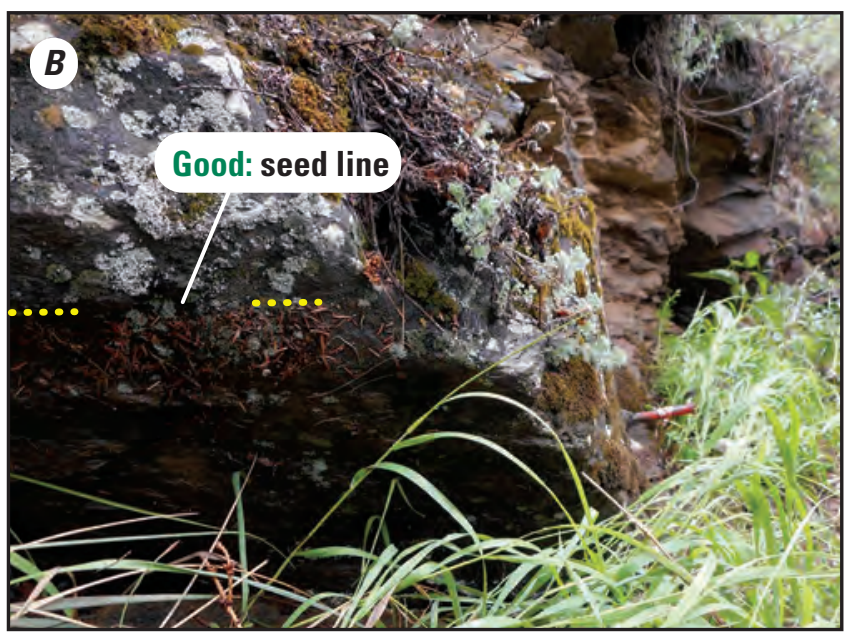

Photographs showing $A$, debris and brush caught on the gage house steps at the Salcha River near Salchaket, Alaska (station number 15484000; http://dx.doi.org/10.5066/F7P55KJN) and $B$, a seed line high-water mark on a rock cliff nearby. Photographs by Heather Best. 


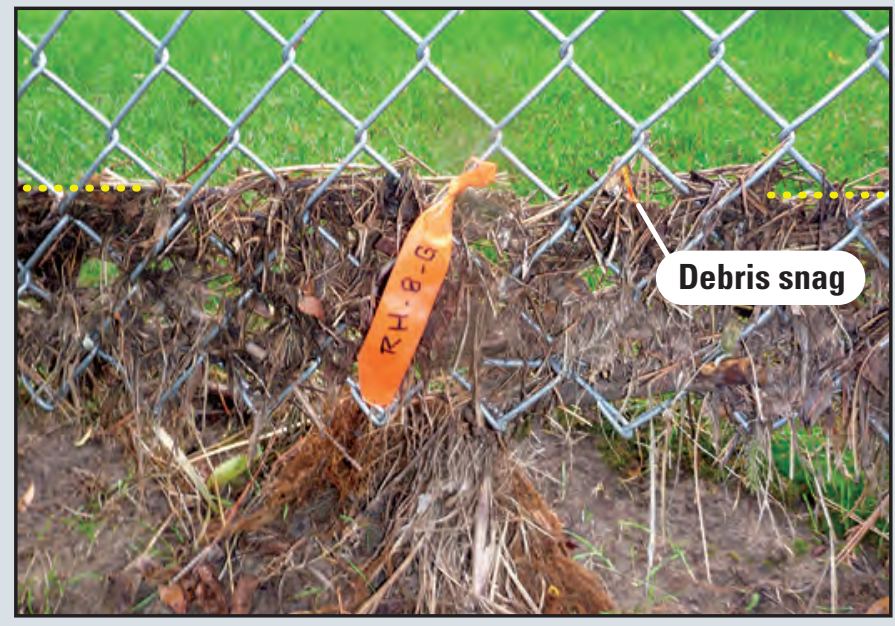

Figure 25. Photograph showing a line of debris collected along a chain-link fence. Photograph by Chad Ostheimer.

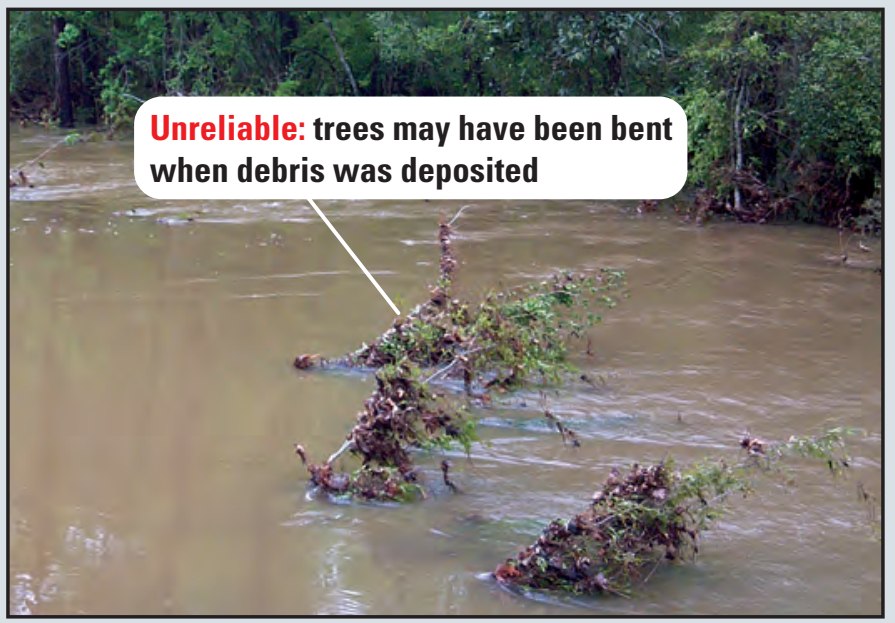

Figure 26. Photograph showing small trees that have been bent down by the force of the floodwaters. The debris caught in the tree branches may have been deposited while the trees were bent directly into the floodwaters, providing an inaccurate high-water mark. Photograph by David C. Sasser, Jr.

\section{A. Standing shrub}

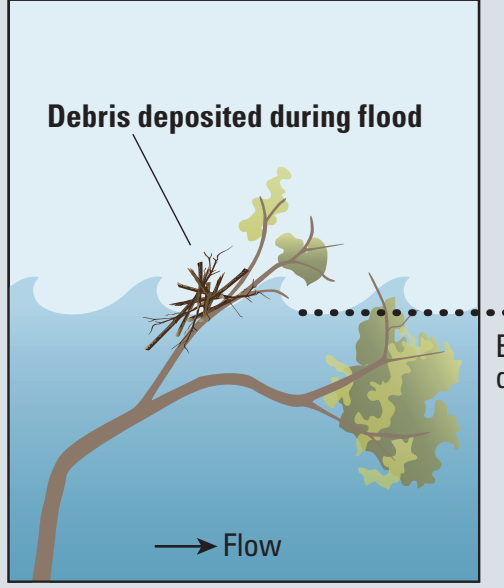

During flood

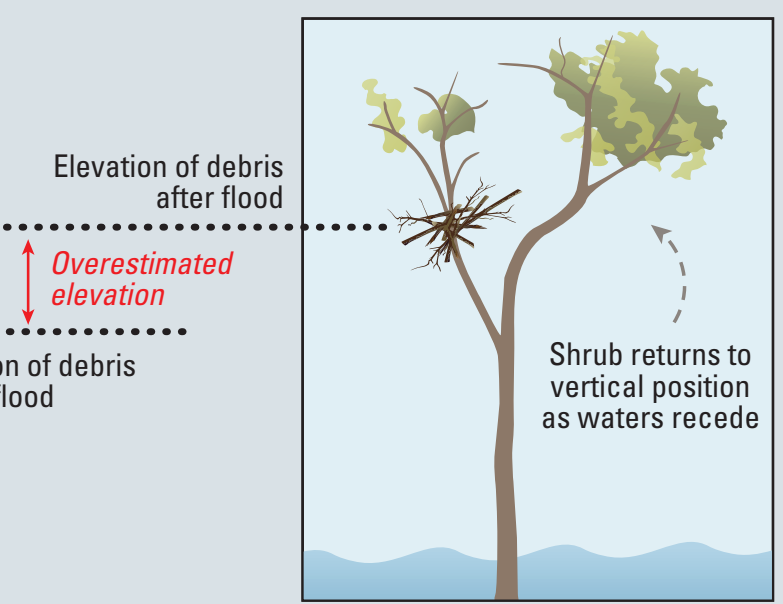

After flood

\section{B. Hanging branch}

Figure 27. Diagrams illustrating how debris deposited onto $A$, bendable shrubs or $B$, hanging branches during a flood can result in misleading high-water marks when the shrub or branch returns to its original position after floodwaters recede. Tree illustrations modified from Kraeer and others (2015).

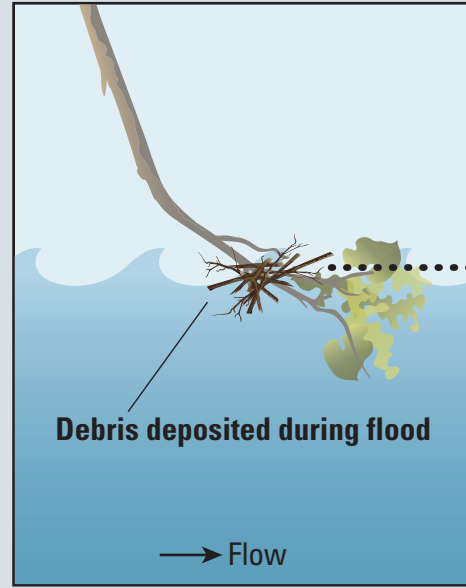

During flood

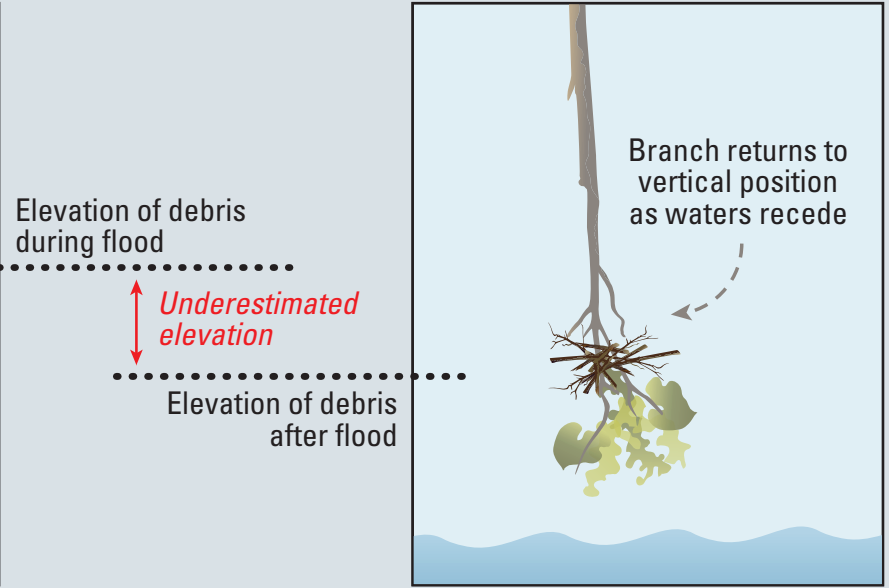

After flood 


\section{Engineered High-Water Mark Indicators}

The USGS relies on high-water marks for peak stage verification at the vast majority of streamgages across the country. In many cases, the marks are left by a flood in the natural environment. But nature's methods also inspire the development of practical man-made recorders that register high-water events consistently and conveniently while protecting the marks for reading at scheduled site visits.

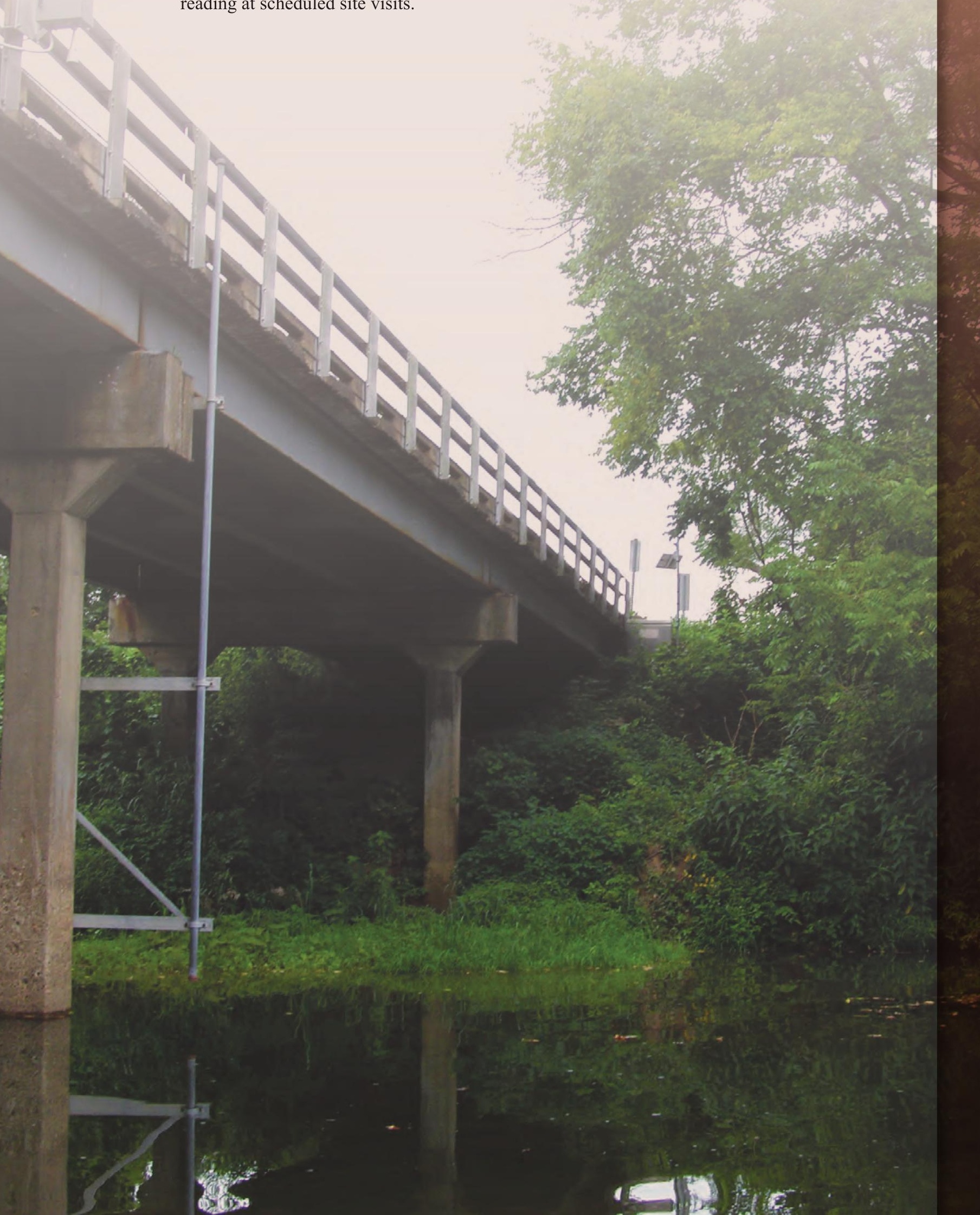




\section{Crest-Stage Gages}

The most common engineered high-water mark recorder in the USGS is a simple device called a crest-stage gage (CSG). A typical CSG consists of a long wooden, aluminum, or plastic stick confined in a vertically-mounted steel pipe that functions as a miniature stilling well, with intake holes at the bottom and a vent hole at the top. A small basket attached to the bottom of the stick holds dry, granulated cork (fig. 28). An index point on each CSG is surveyed to a known elevation shortly after installation and periodically re-surveyed to document any shifting over time. During a flood event, water rises inside the pipe, and a floating layer of granulated cork rises with the water and clings to the peak level on the stick (fig. 29). The cork line remains on the stick, protected by the surrounding pipe, until a larger flood floats the cork line higher or until a hydrographer retrieves the stick and records the cork-line height. Adding this height to the CSG index-point elevation produces the peak gage height. The hydrographer then prepares the CSG to register the next peak by cleaning the stick, replenishing the cork, and placing the stick back into the pipe (Sauer and Turnipseed, 2010).

Bridge and culvert structures present easily accessible locations for mounting CSGs (fig. 30), but hydraulic effects such as drawdown at inlet structures must be considered in CSG placement. Placing a CSG upstream by at least one culvert width (including wingwalls) or by one bridge opening width will avoid drawdown effects. A single, well-placed CSG can be used to verify recorded peak stages at a streamgage. CSGs placed at key points around the structure also can be used to collect data for computing indirect streamflow measurements (Bodhaine, 1982).

Exposure to floating flood debris (such as trees, trash, and ice) that would damage the CSG should be considered during placement. Mounting CSGs behind protective structures such as bridge piers or large trees can provide needed protection if drawdown is considered. If a protected location cannot be found for a CSG covering the desired range of stage, the range can be divided among multiple, shorter CSGs that can be individually located to reduce exposure and improve the effectiveness of each gage.

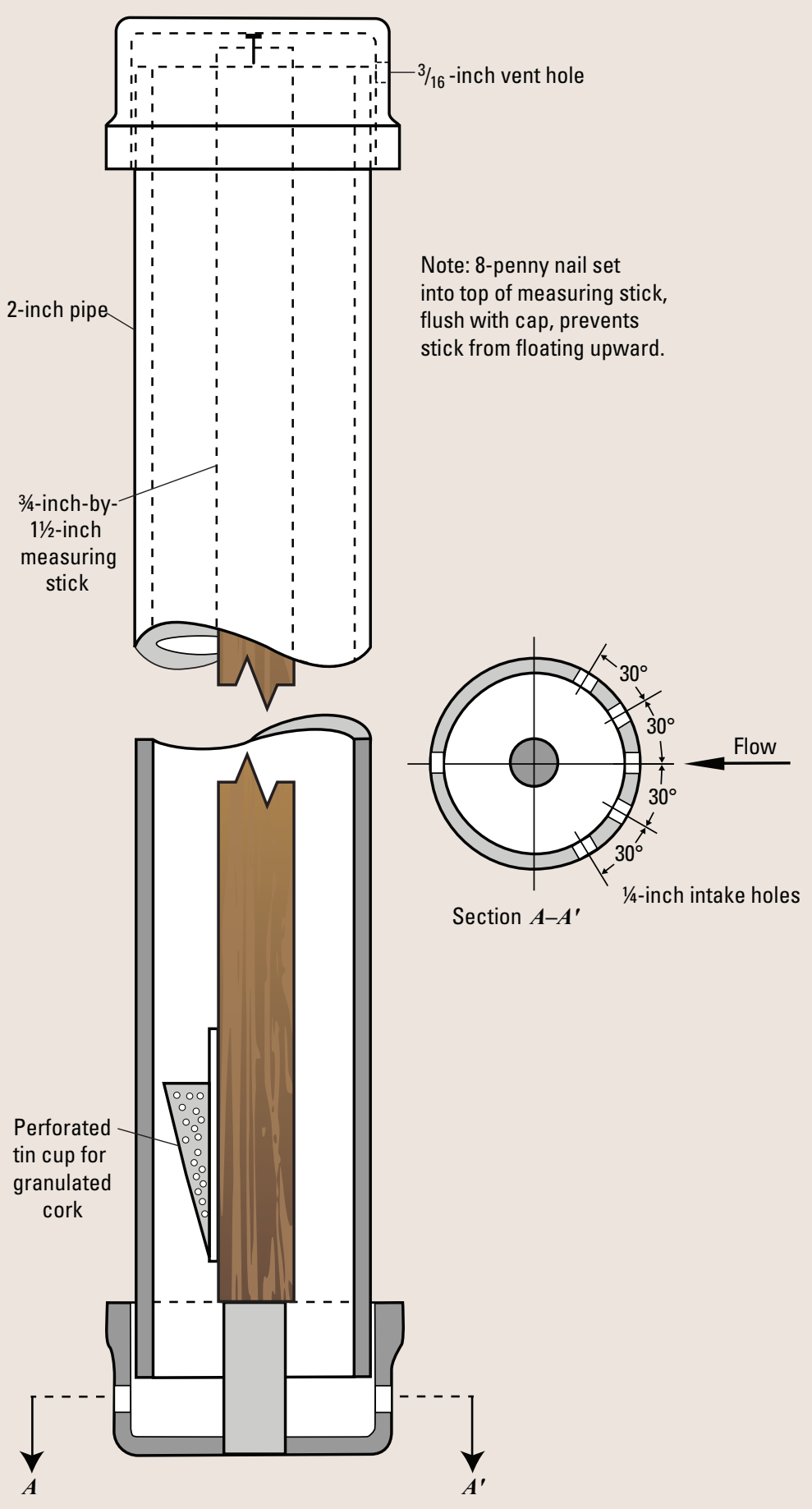

Figure 28. A typical crest-stage gage. Modified from Sauer and Turnipseed (2010). 


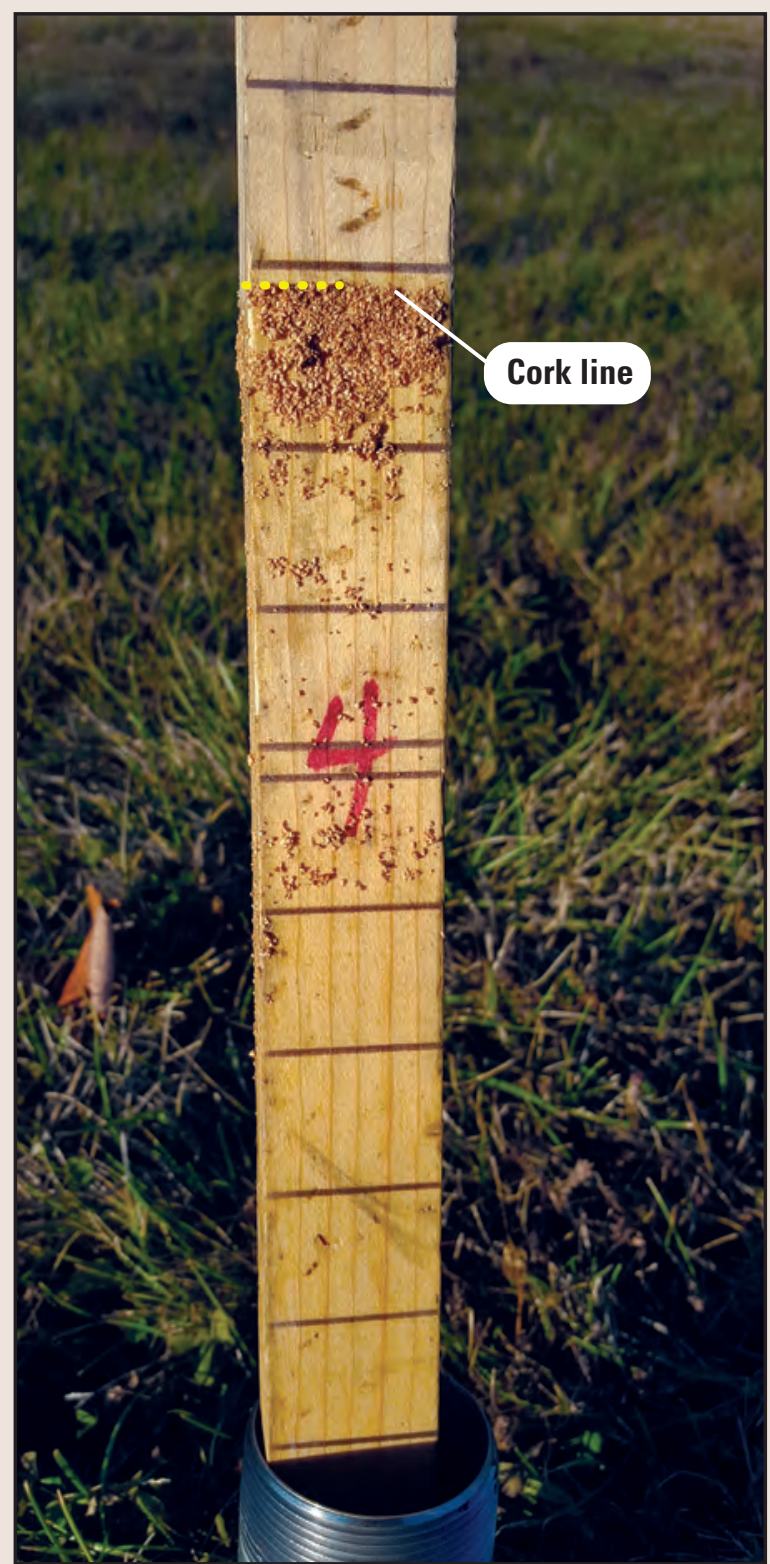

Figure 29. A cork line from a crest-stage gage. The top of the cork line represents the peak water surface recorded by the crest-stage gage.

Figure 30. Crest-stage gages $A$, mounted on the downstream side of a bridge pier; $B$, mounted to a tree; and $C$, mounted to a wingwall in the drawdown zone where the gage cannot collect the proper headwater elevation. Photograph $B$ by Ben Rivers; photograph $C$ by Karl Winters.
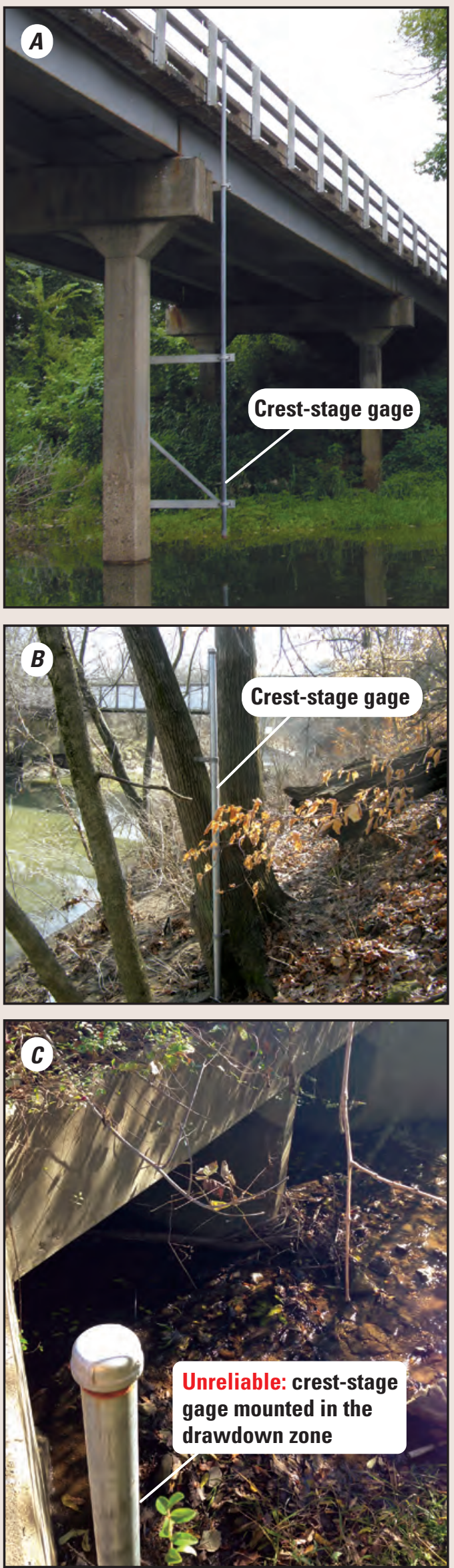


\section{Crest-Stage Indicators}

In addition to cork-based CSGs, some continuous streamgages consist of stilling wells equipped with floats attached to long, graduated steel tapes that have their own high-water marking indicators (fig. 31). As the tape moves up and down with the float, an electronic recorder at the top of the well records the float level. When water rises inside the well during a flood, a high-water indicator clip attached to the steel tape rises with the float. As the clip encounters the underside of the gage platform, the clip is forced to slide down the tape. The float and tape return to a lower position as the floodwaters

\section{A. During normal flow conditions}

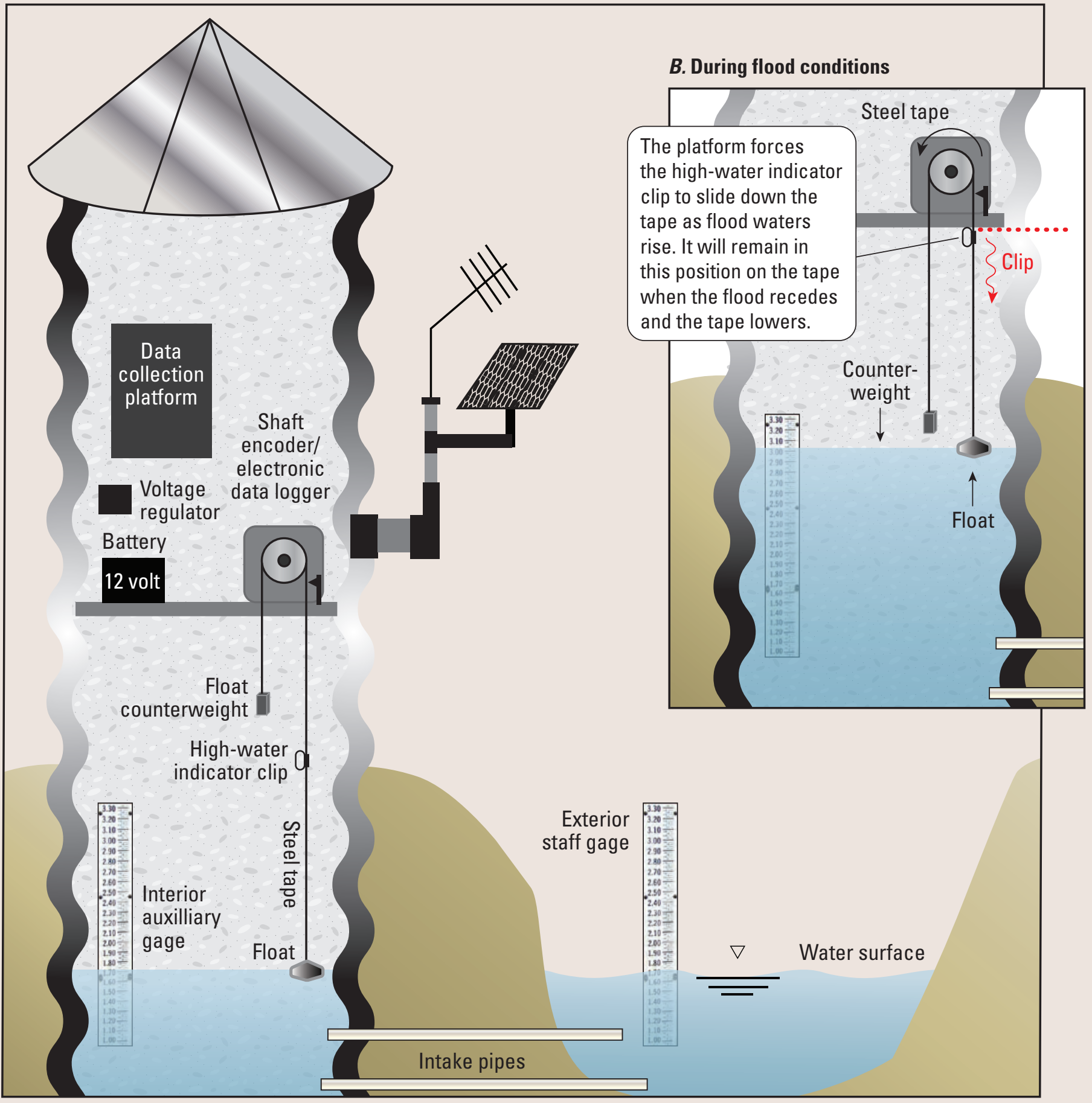

Figure 31. A stilling well with steel tape shaft encoder and high-water indicator clip during normal flow conditions and (inset) during flood conditions. Modified from Sauer and Turnipseed, 2010. 
recede, and the clip remains in the same location on the tape, recording the peak offset. During the post-flood visit, the hydrographer raises the tape until the clip again contacts the underside of the platform; the hydrographer then records the peak stage indicated by the tape at that position. Before leaving, the hydrographer resets the clip at the top of the tape in preparation for the next event (Sauer and Turnipseed, 2010). Plugged or sluggish well intakes will affect the recorded peak stage and the clip reading equally; therefore, caution should be taken when clips are used to verify recorded peak stages. High-water clips have also been known to slip. For these reasons, independent high-water marks or other crest-stage indicators are preferred.

Some USGS hydrographers have also experimented with crest-stage indicators that are made by applying paint to a smooth vertical surface followed by a vertical chalk line drawn

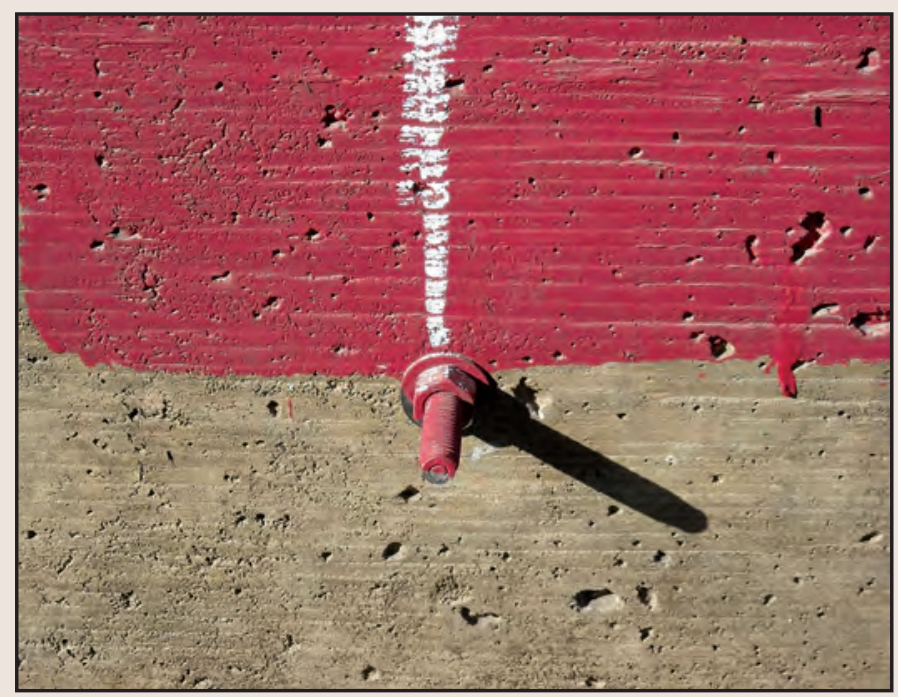

Figure 32. A crest-stage indicator under a bridge pier. This crest-stage indicator uses a vertical chalk line, a red painted background, and a surveyed bolt as a reference mark. Photograph by Craig Painter.

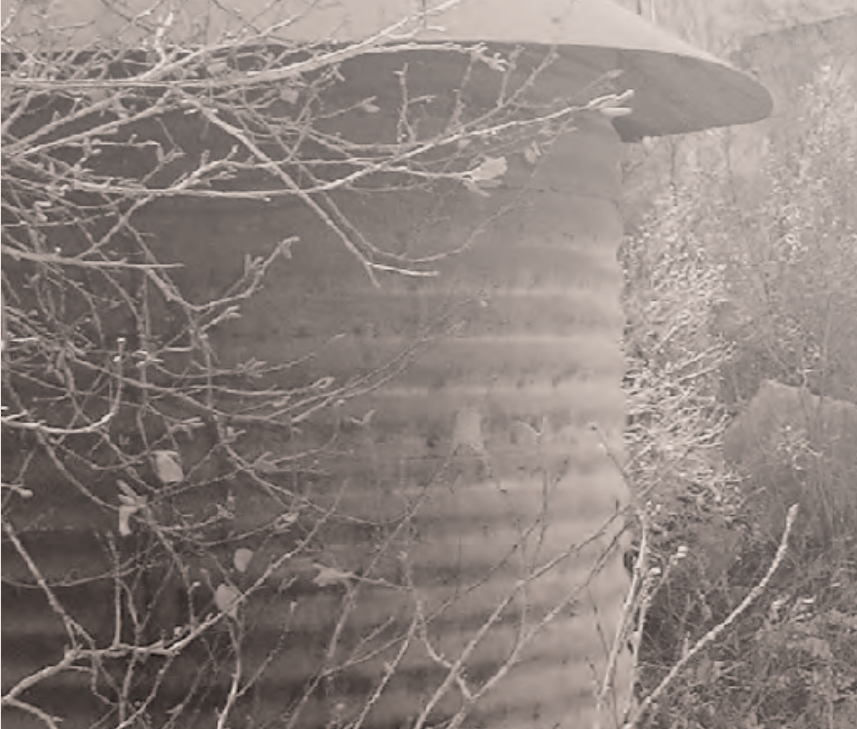

up from a reference point of known elevation (fig. 32). As long as the chalk line can be sufficiently protected from wind and blowing rain, a portion of the chalk line will be washed away in a flood, leaving behind clear evidence of the peak stage. Hydrographers measure the distance between the reference point and the remaining chalk line to determine the peak stage of the flood (fig. 33). Chalk lines are typically drawn on piers under a protective bridge deck, and experiments with different types of materials have determined that chalk used by a parking-control officer and blue traffic zone marking paint work together effectively. Wave action on the sides of piers and drawdown on the downstream sides of piers can create considerable uncertainty in chalk line systems; therefore, hydrographers must consider the placement of these systems and the applicability toward their intended purpose (Brian Loving, U.S. Geological Survey, oral commun., 2015).

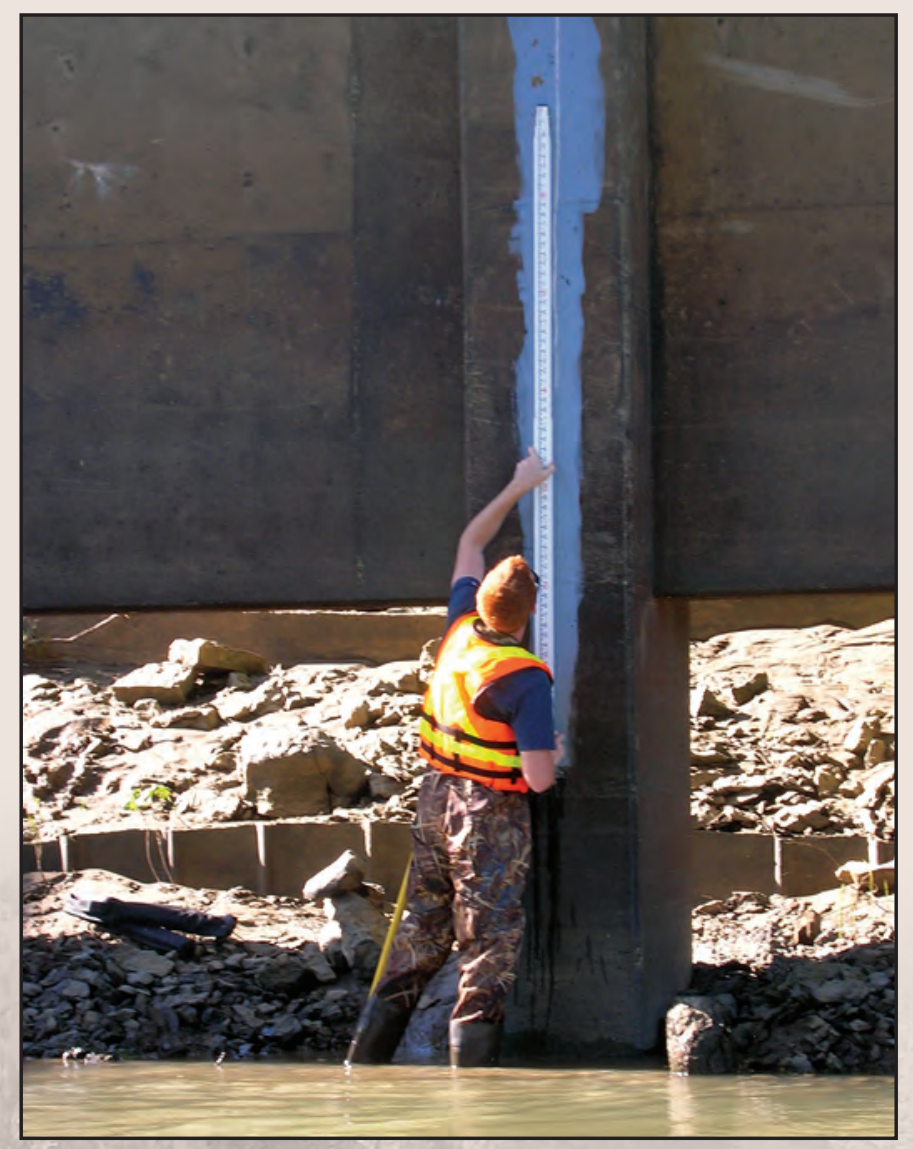

Figure 33. A hydrographer measuring a chalk line high-water mark. Photograph by Craig Painter. 


\section{Image Capture}

Modern technology also plays a role in high-water mark collection. Improvements in data storage and transmission have increased the use of image-capture devices at key stream locations, including streamgages. Still images captured at regular intervals and event-triggered video devices provide increasingly detailed evidence of floods that was not previously practical. A screen-capture of a USGS live streamgage webcam on September 8, 2015, is shown in figure 34. At this site, webcam users can take control of the camera and zoom in to capture instantaneous images of the river, including realtime observations of the current stream stage. During major floods, USGS operators can take control of the webcam to collect visual verification of the event.

The general public can also be instrumental in providing evidence of high water. Peaks can sometimes be garnered from photographs, videos, or eye-witness news accounts where local observers or video-recording equipment captured the peak water surface elevation, either intentionally or inadvertently (Association of State Floodplain Managers, 2014). Determining if event-based accounts captured the actual peak of a given flood is difficult; therefore, event-based data must be used with care.

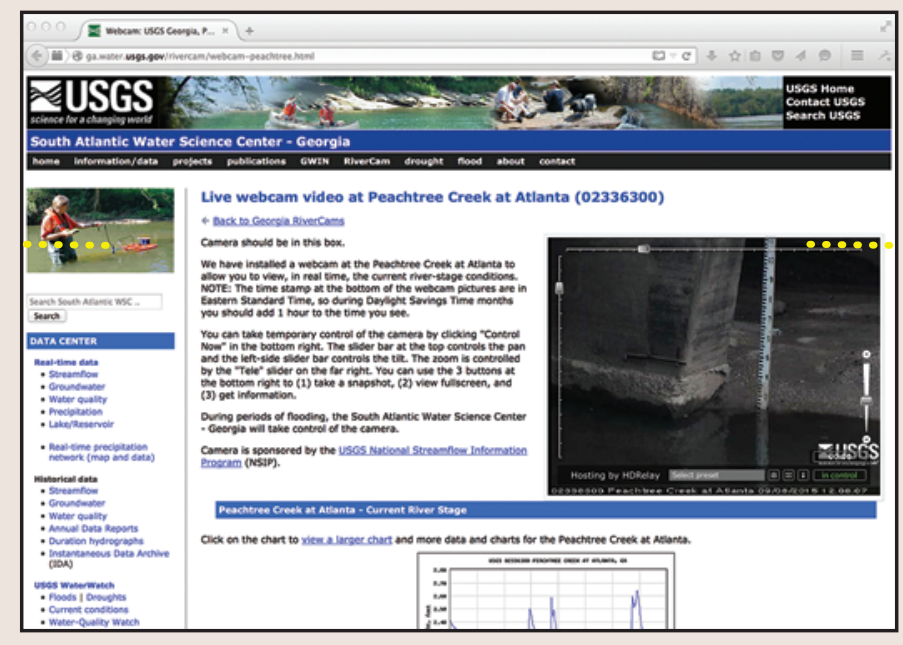

Figure 34. Screen capture of a U.S. Geological Survey South Atlantic Water Science Center live webcam, captured on September 8, 2015, at http://ga.water.usgs.gov/rivercam/webcampeachtree.html. The webcam image has been manually zoomed in to focus on the staff gage.

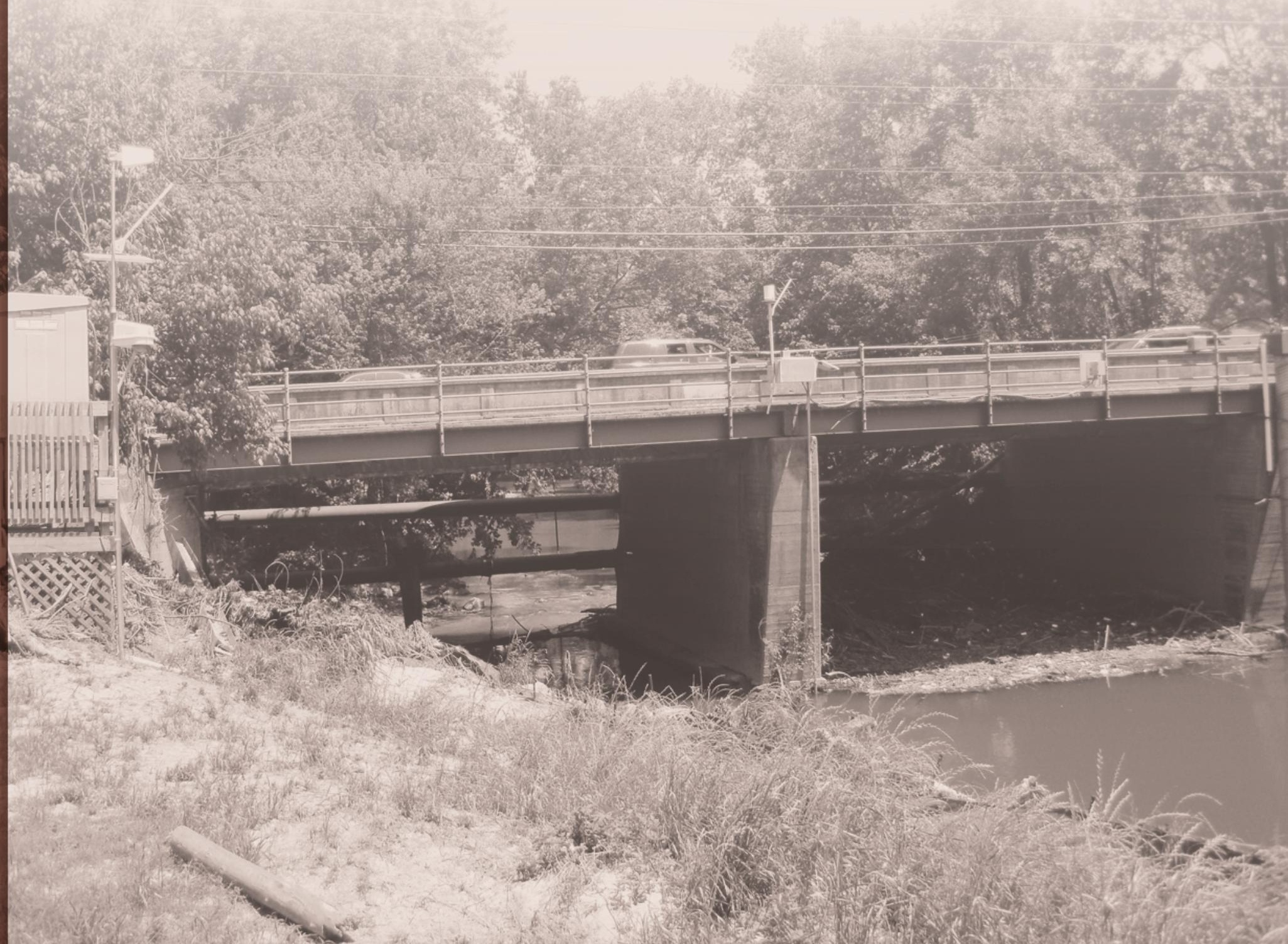




\section{Preserving Data}

The goal of identifying high-water marks is to collect useful elevation information before nature or human activity has destroyed the evidence. Paleoflood evidence may remain for centuries, whereas perishable high-water marks must be identified and recorded quickly. Rain, dew, wind, sun, and gravity degrade high-water marks, sometimes removing the marks in a matter of hours or days. Likewise, cleanup efforts can be prompt, taking advantage of short-term public interest and emergency funding (see "St. Vrain Creek, Colorado" narrative). Therefore, a quick response time for measuring highwater mark elevations or transferring the marks to protected objects or locations at the same elevation is vital to preserving high-water mark data and involves the proper location, evaluation, marking, and recording of data in the field.

\section{Location}

Choosing locations to collect high-water marks is largely dependent on the intended use of the indicated water surface elevation. The following four subsections summarize some basic guidelines for choosing where to look for high-water marks and the quantity of marks needed for success in each application.

\section{Peak Stage Verification}

When high-water marks are used for peak stage verification at a gage, the marks should be collected within a reach that contains the same controlling features influencing the streamgage and near enough to the gage to reduce errors in horizontal level surveying. Stage data in the USGS are

\section{Saint Vrain Creek, Colorado}

In mid-September, 2013, after several days of sustained heavy rainfall and catastrophic flooding in Colorado, crews surveyed the reach at the I-25 bridge over Saint Vrain Creek near Longmont, Colorado. A contracted-opening indirect measurement was needed at the I- 25 bridge; therefore, high-water marks were surveyed at the approach cross section.

Large debris lines were visible along the upstream roadway embankments and on the sloping abutments through the bridge on both banks, with an uncertainty of roughly 0.5 foot; however, identifying more precise high-water marks was more challenging. After a thorough

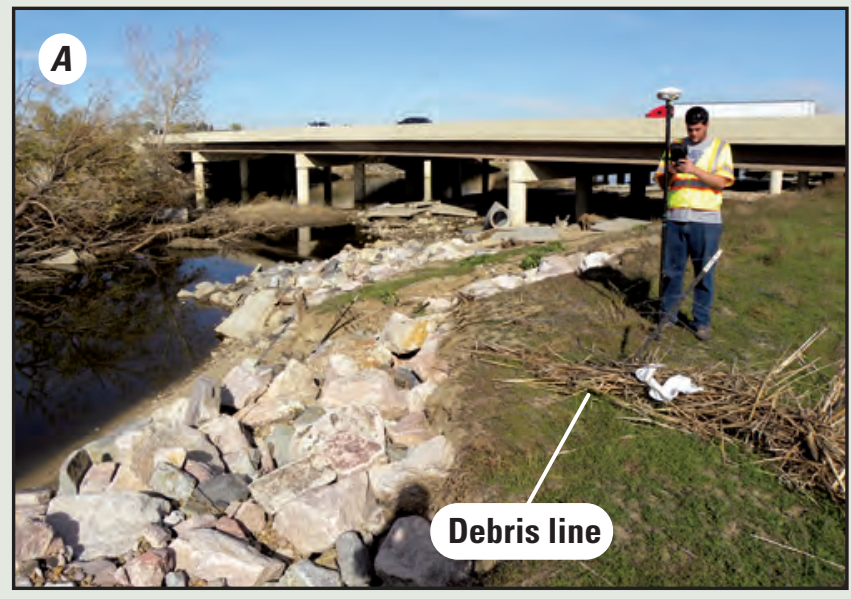

Photographs showing $A$, a large debris high-water mark along a roadway embankment near the $\mathrm{I}-25$ bridge opening on Saint Vrain Creek near Longmont, Colorado and $B$, a fine mud line high-water mark on a picnic shelter in Saint Vrain State Park, Colo. search, fine mud lines (uncertainty less than 0.03 foot) were identified on several picnic shelters and on the vent stack of an outhouse in a state park adjacent to the creek. Fortunately, these

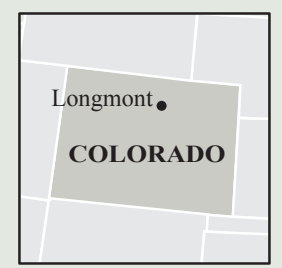
precise high-water marks were identified before participants in a work-release program could pressure wash the picnic shelters and perform other cleanup so that the state park could reopen. Commonly, man-made structures reveal the best high-water marks but do not hold them for long.

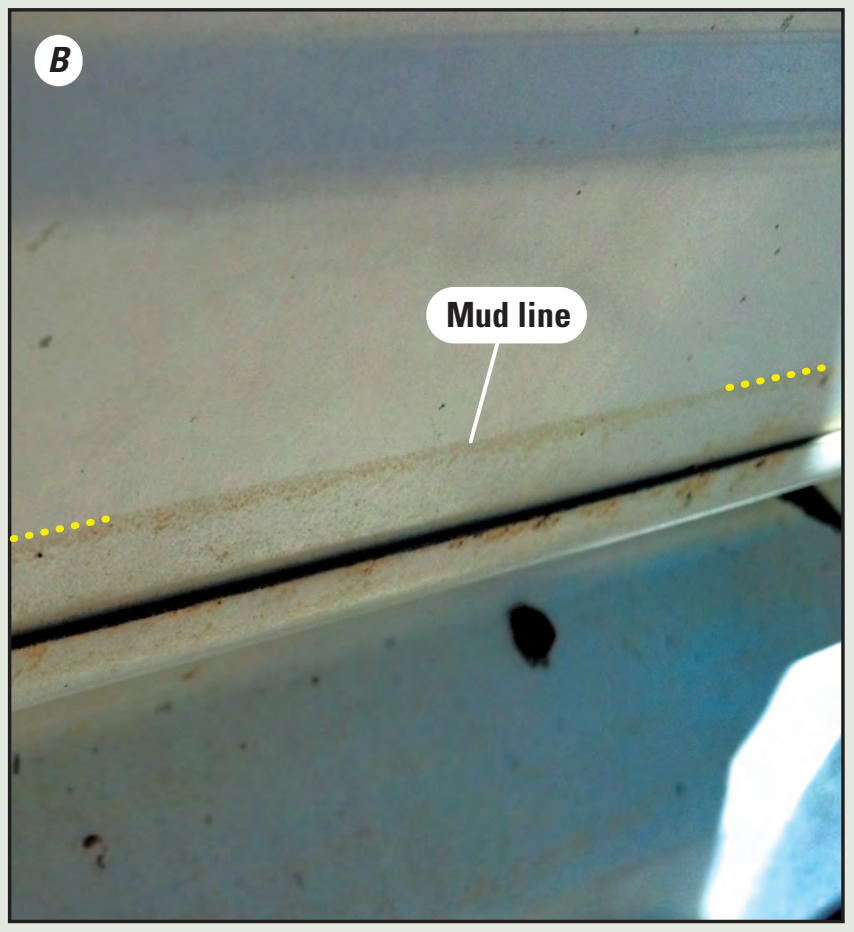


generally held to a standard of 0.01 feet or 0.2 percent of the effective stage (Sauer and Turnipseed, 2010). The best quality high-water marks are needed to verify peaks at streamgages; therefore, engineered high-water mark collection devices may be installed at streamgages. If high-water marks in the natural environment are needed, an average of two or three high-water marks will improve confidence in the stage verification.

\section{Flood Inundation Studies}

Flood inundation studies are typically concerned with the spatial extent of flooding in a defined area. Consequently, horizontal accuracy becomes as important as vertical accuracy of the water surface, and the importance of gathering enough marks to determine the extent of the high-water inundation cannot be overstated. A small, rural stream reach might only require 5 or 10 high-water marks to adequately define the extent of the flooded water surface, but an urban setting with road embankments, storm sewers, culvert connections, and other urban structures may require many times more highwater marks to define water surface elevations within bounded or partially-bounded sections. In addition, distance-to-ground is commonly an important data element to collect, and care may be needed to associate high-water marks with a known vertical datum and nearby streamgages or other flood stage indicators if the results will be used for future flood warning.

\section{Indirect Streamflow Measurements}

When collecting high-water marks for indirect streamflow measurements, various published guidelines dictate ideal stream reach locations and high-water mark hunting locations relative to the applicable controlling structures. Indirect measurement techniques should be familiar to hydrographers so that the best high-water marks can be collected for a given indirect measurement type. The publications listed in table 1 provide the necessary guidelines, which are too detailed to repeat in this manual.
If this manual is being read online, these publications can be accessed by selecting the appropriate book/chapter listed in table 1. The USGS Floods Web site at http://water.usgs.gov/ floods/resources/iqm/ (U.S. Geological Survey, 2015b) also provides links to all of the publications in table 1 and additional indirect measurement resources.

Hydrographers who are new to high-water mark hunting may be unfamiliar with the amount of data required to adequately define the water surface along a reach, especially for slope-area indirect computations. Streambed slope, channel roughness, channel variations, reach length, ideal crosssection locations, and general efficiency are factors that figure into the number and locations of necessary data points. Until hydrographers become familiar with these factors, the following general suggestions for collecting marks along slope-area indirect measurement reaches may be beneficial. Low-gradient streams in the plains and coastal regions may need only 7 to 10 high-water marks per 100 feet to accurately represent mild water surface slopes. High gradient streams such as those in mountain regions typically need denser collections of highwater marks to define the frequently changing water surface slope. In these situations, 20 to 30 marks per 100 feet of reach may be desirable. Ultimately, the number of marks needed to define a reach will be site dependent. Hydrographers should become as familiar as possible with the methods referenced in table 1, and the search for high-water marks should be directed by a person knowledgeable in the aforementioned techniques.

\section{Coastal Flood Studies}

Storm tides are formed by the complex interaction of normal (gravitational and inertial) tides and additional winddriven surge from intense storms. Coastal floods that are caused by storm tides differ considerably based on the local coastal bathymetry and each event's timing, intensity, location, and setting (whether developed, undeveloped, or protected; National Oceanic and Atmospheric Administration, 2015). In addition, storm-tide flooding typically develops as a sequence

Table 1. Publications of indirect measurement techniques including the proper location of high-water marks.

\begin{tabular}{ccc}
\hline Book/chapter & Title (author, year) & Indirect measurement type or purpose \\
\hline TWRI 3-A1 & $\begin{array}{c}\text { General field and office procedures for indirect discharge } \\
\text { measurements (Benson and Dalrymple, 1984) }\end{array}$ & General indirect measurement guidelines. \\
TWRI 3-A2 & $\begin{array}{c}\text { Measurement of peak discharge by the slope-area method } \\
\text { (Dalrymple and Benson, 1988) }\end{array}$ & Reasonably straight, open channels. \\
TWRI 3-A3 & $\begin{array}{c}\text { Measurement of peak discharge at culverts by indirect } \\
\text { method (Bodhaine, 1982) }\end{array}$ & Enclosed culverts. \\
TWRI 3-A4 & $\begin{array}{c}\text { Measurement of peak discharge at width contractions by } \\
\text { indirect methods (Matthai, 1976) }\end{array}$ & $\begin{array}{c}\text { Open channel width contractions (for example, bridge } \\
\text { openings). }\end{array}$ \\
TWRI 3-A5 & $\begin{array}{c}\text { Measurement of peak discharge at dams by indirect } \\
\text { methods (Hulsing, 1968) }\end{array}$ & \begin{tabular}{c} 
Flow over dams, weirs, and road embankments. \\
\hline
\end{tabular}
\end{tabular}


of flows coming inland from the coast and return flows heading back out to the ocean or large lake.

The bidirectional nature of storm tides may leave behind pairs of high-water marks; first from a higher incoming flood wave and second from a lower recession flow in the opposite direction. The higher mark representing the peak storm tide is commonly less defined than the lower mark because of wind effects during the inflow and because of greater availability of sediment and debris in the return flow. In addition, the higher mark may have greater uncertainty because of runup or splash caused by the interaction of incoming wind and water against obstructions. When searching for high-water marks near roadways in urban areas, a hydrographer should watch for marks that may have been biased high by waves caused by motorists attempting to drive through inundated roads.

Storm tides typically create backwater effects on coastal streams when downstream flow encounters increased coastal water surface elevations and powerful upstream forces. These effects may include higher water surface elevations for a given flow rate, slower downstream flows, increased tidal (reverse) flows, or reverse flows in reaches that are typically too far upstream to encounter tidal flows. Thus, to accurately characterize the extent of the flood event, near-shore and inland high-water marks should be collected.

High-water marks near and along the shore are typically collected for storm-tide model calibration (Dietrich and others, 2011; Hope and others, 2013), whereas high-water marks collected farther inland are focused on urban areas for documenting inundation extent and severity. Because coastal flood studies are often concerned with the spatial extent of flooding, hydrographers may follow guidelines similar to those used in flood inundation studies as discussed previously. Depending on the event severity, a few high-water marks may need to be identified close together in a small area, or many high-water marks may need to be identified as the hydrographer travels inland (sometimes several miles) and identifies communities affected by the event. During larger events, the most useful locations for identifying and documenting high-water marks may be determined by querying local emergency command centers that have been setup for the event. Additional marks should be collected around bays, inlets, and river mouths to capture flood variability because of wave runup or upland flooding. Collectively, these high-water marks are essential for verifying peaks at streamgages, calibrating coastal flood models, and understanding coastal processes. Priority may also be given to collecting high-water marks around critical infrastructure such as bridges, power plants, and water treatment plants; data near these flood-sensitive areas contribute to flood impact assessments and future planning (Scott Hedgecock, U.S. Geological Survey, oral commun., 2015; Christopher Smith, U.S. Geological Survey, oral commun., 2015).

\section{Evaluation}

Regardless of application, each high-water mark should be evaluated at the time of discovery based on the vertical range of peak surfaces that could be described by the evidence. This vertical range (in feet) is referred to as the uncertainty of the high-water mark. Hydrographers should consider the conditions that formed a high-water mark and then assign a numeric uncertainty value to the mark. For example, the cut line shown in figure 15 might be assigned an uncertainty value of " \pm 0.3 foot" if such a range adequately accounted for slumping. In contrast, a hydrographer might assign a much smaller uncertainty value of " \pm 0.1 foot" to the well-defined debris snag shown in figure 25 . Recording the uncertainty as a numeric value informs the data user's decisions on how to best use the data, and how much error in ensuing models and computations are attributable to the marks themselves. For example, the peak stage recorded at a streamgage can be considered trustworthy if that stage is within the uncertainty range of nearby high-water marks. Likewise, plotting the uncertainty range of each mark in an indirect streamflow measurement will ensure that the water surface profile traces reasonable lines through the plotted marks. Without specific uncertainty data, most applications of high-water marks will suffer in quality or make inappropriate use of the marks. As discussed in the next sections, uncertainty values should be recorded in field notes and on high-water mark flagging where possible. Photographs of each mark and its environment, as discussed in the "Marking and Flagging" section, will help to substantiate the rating or inform a later rating modification if further analysis casts suspicion on the mark.

\section{Marking and Flagging}

Hydrographers use various types of markers to preserve the elevation of evidence left by a flood until the high-water marks can be surveyed, even after the event evidence has been lost. Markers and flagging also facilitate locating those marks again if the surveying will be done in the future or by a different hydrographer, or both. Typical markers include stakes, nails, bright-colored survey flagging tape, wire flags, USGS marking tabs, paint, permanent ink markers, and chiseled marks. Examples of some of these markers are shown in figure 35. Wire flags or stakes tied with flagging tape may be driven into the ground at the edge of cut lines, wash lines, or debris lines. Stakes should be clearly documented, identifying if the top or the base of the stake represents the high-water mark. Nails can also be used to mark ground-based high-water marks, or they can be driven into tree trunks or walls to indicate a seed line or mud line. Nails should be further identified with USGS marking tabs or flagging tape to make them easy to find. Permanent ink markers can be used to trace a mud line or seed line on structures, or spray paint can be used with a piece of paper or other straight edge to form a precise line that defines the high-water mark. 

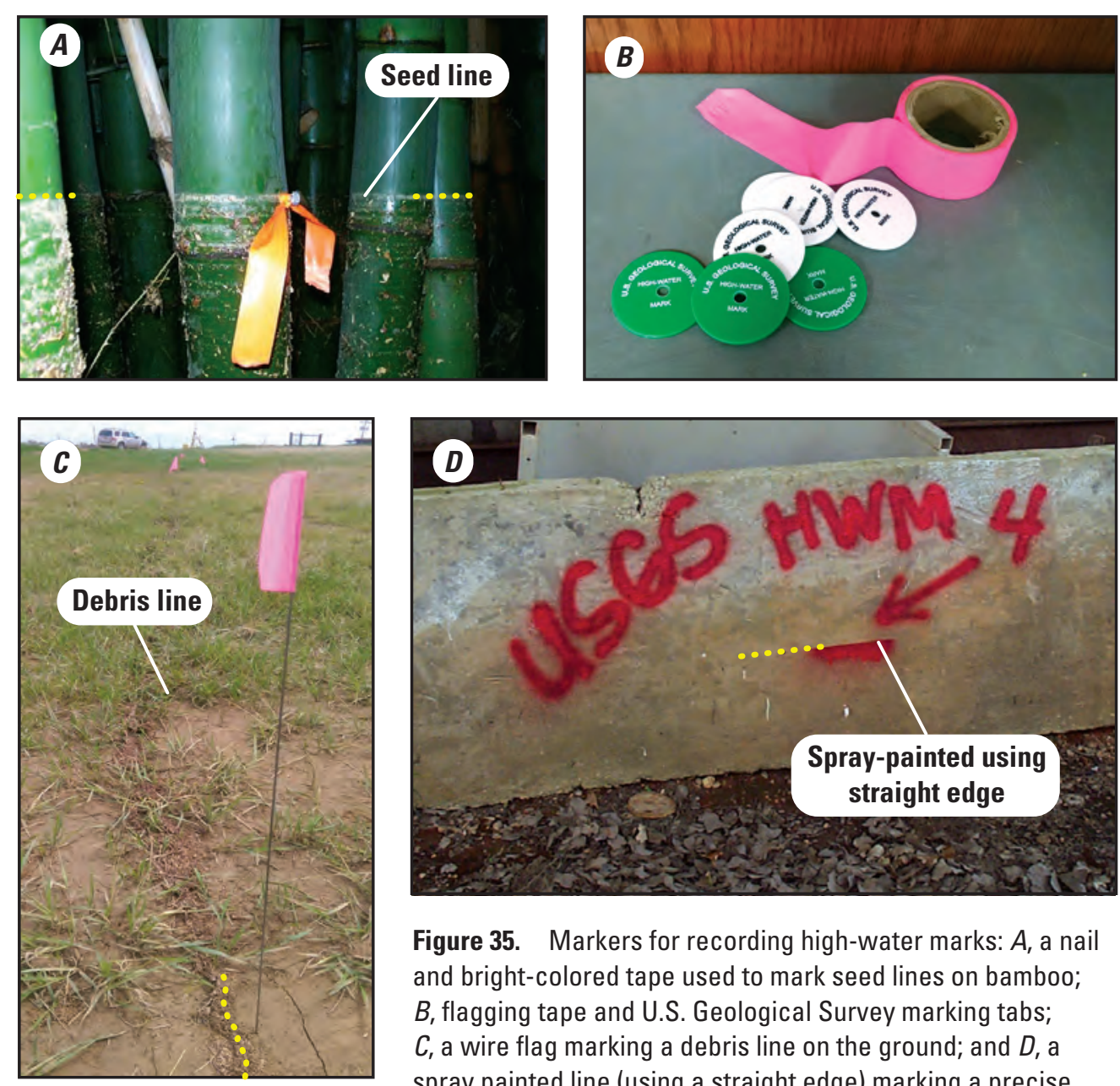

Figure 35. Markers for recording high-water marks: $A$, a nail and bright-colored tape used to mark seed lines on bamboo; $B$, flagging tape and U.S. Geological Survey marking tabs; $C$, a wire flag marking a debris line on the ground; and $D$, a spray painted line (using a straight edge) marking a precise high-water mark on a concrete divider. Photograph $B$ by Walter Killion.

In most cases, survey flagging should be included with the mark and annotated with the date, uncertainty, and unique identifier for the high-water mark. A common convention is to refer to marks on the left and right sides of a stream as "LH-X-u" and "RH-x-u" where " $\mathrm{x}$ " is a unique identifying number assigned to each mark and " $u$ " is the uncertainty. USGS hydrographers follow the convention of identifying left and right sides of a stream as viewed when facing downstream. When recording uncertainty on flagging tape and labels, the numeric uncertainty can be written on the tape, or shorthand uncertainty abbreviations can be used (fig. 20); however, abbreviations should always be associated with a numeric value properly evaluated for each mark and recorded in the notes. A common USGS shorthand standard for uncertainty is listed in table 2 (modified from Rydlund and Densmore, 2012). For example, the flagging for a marker along the cut line in figure 15 might be labeled "LH-9-0.3" (preferred), indicating that it is the ninth mark on the left side having uncertainty of \pm 0.3 foot, or the label could read "LH-9-P."
Table 2. High-water mark uncertainty shorthand.

\begin{tabular}{ll}
\hline \multicolumn{1}{c}{ Amount of vertical uncertainty } & Uncertainty (shorthand) \\
\hline Within \pm 0.05 foot. & Excellent (E) \\
Within \pm 0.10 foot. & Good (G) \\
Within \pm 0.20 foot. & Fair (F) \\
Within \pm 0.40 foot. & Poor (P) \\
$\begin{array}{l}\text { More than } \pm 0.40 \text { foot. } \\
\text { High-water mark defines the } \\
\text { minimum height of the peak, } \\
\begin{array}{l}\text { but peak may have been higher } \\
\text { to an unknown extent. }\end{array}\end{array}$ & At least this high (ALTH) \\
\hline
\end{tabular}


The "at least this high (ALTH)" shorthand is useful for flood frequency computations where statistical methods are available for using these data. The remaining categories are useful for most other applications of high-water marks. Uncertainty values that cannot be described by one of the abbreviations in table 2 should be noted numerically. For clarity, especially where coastal and riverine high-water marks are being collected for the same event, the same system of shorthand should be used for all high-water marks for a given event. When visiting crews assist with high-water mark collection, numeric uncertainty values should be recorded unless all crews have agreed upon a common shorthand system.

Consideration should be given for future surveying of high-water marks if the flagging crew will not be immediately surveying the marks. Additional flagging tied to nearby objects will lead surveyors to high-water marks that would be difficult to see from a distance, especially in wooded areas. Remember that flagging, stakes, and nails driven into tree trunks need to be removed after all high-water marks in the area have been surveyed for elevation.

When marking locations with nails, stakes, or other methods, consideration should be given for the common tools and methods that will be used in the ensuing survey. For example, a hydrographer marking a seed line on a tree with a nail should try to align the top of a nail with the top of the seed line. This method allows the surveyor to rest the shoe or

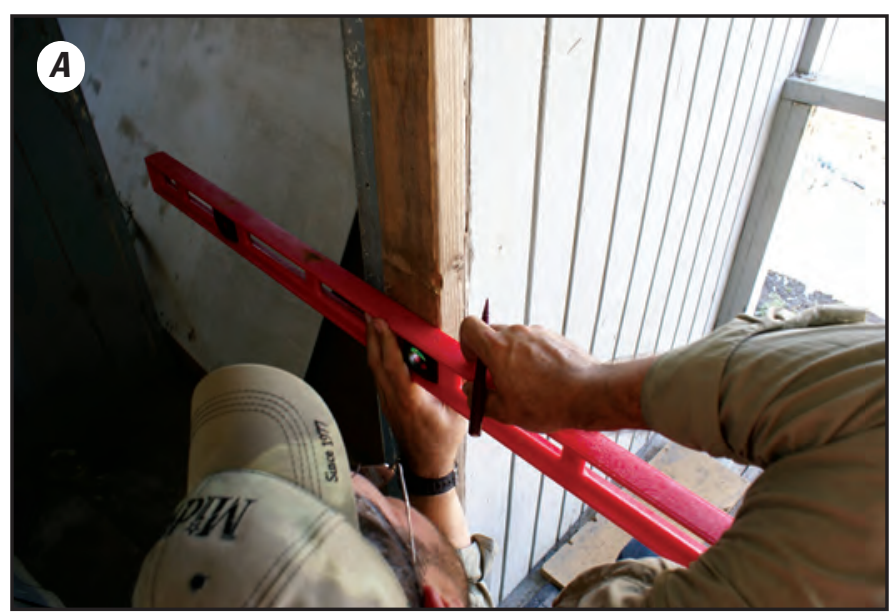

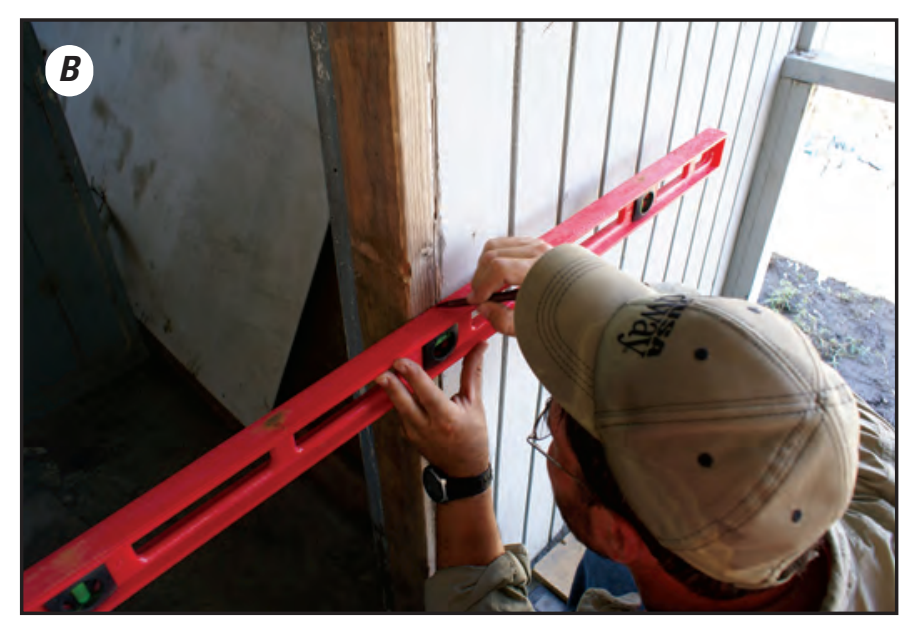

prism of the survey rod directly on top of the nail for the best elevation measurement. High-water marks in locations with unobstructed space overhead expand the surveyor's options for choosing appropriate rod heights or Global Navigation Satellite Systems (GNSS) setups, depending on the survey method used.

Marks that would be difficult to survey, such as those inside flooded structures, can be transferred to more accessible locations with the same elevation by using a carpenter's level (fig. 36). If water remains ponded at a common level within and around a structure, high-water marks can also be transferred to other locations on the structure by taping up from the water surface to the high-water mark and then making a new mark on the outside of the structure using the same distance taped up from the common water surface.

Where possible, field crews should obtain permission from landowners before placing permanent or semipermanent markings on private property. If such permission is not granted, hydrographers should measure up or down from a permanent surface on the structure or surrounding pavement; detailed notes and photographs help to ensure that future survey crews will identify and measure to the exact same surface. Field crews also should coordinate efforts with onsite emergency personnel, investigative agencies, or local emergency command centers as to when crews will be marking and flagging in the wake of a significant disaster.

Figure 36. A hydrographer transferring a high-water mark around the corner of a structure using a simple carpenter's level for easier surveying. Photograph by William C. Vervaeke. 
Field preparation includes arriving on site with the necessary tools and materials needed to properly complete a high-water mark investigation. The list below includes many of the tools needed for identifying and preserving high-water mark data:

\section{- General}

- pocket knife

- backpack or other tool carrier

- machete for reaching areas of dense brush

- boat for reaching high-water marks in swampy or still-inundated areas

\section{- Safety}

- high-visibility safety vest for working around roadways

- wading boots, waders, or snake boots

- personal flotation devices

- flashlight

- sunscreen

- bug spray

- water and snacks

- first aid kit

\section{- Marking, flagging, and preliminary survey}

- USGS plastic or metal tab markers

- nails (duplex nails are easier to flag and remove)

- hammer

- flagging tape

- wire marker flags

- surveyor's hand level

- steel rebar, wooden stakes, or both

- permanent marker or grease pencil

- tape measure, engineer's rule, or steel tape

- carpenter's level

- compass

- rangefinder

- two-way radios

- total station, tripod, rod, and prism for preliminary computations

\section{- Recording}

- field notebook or field tablet device, or both

- cellphone or photograph/video camera

- small dry-erase board and marker for photograph documentation

- handheld Global Positioning System (GPS) for coarse location of high-water marks

- special note sheets and forms

- Additional paleoflood tools

- sample containers for paleoflood evidence collection an

- shovel

- soil auger

- trowel

paintbrush

Finally, consider the safety of persons who will use flooded areas in the future. Nails left in trees after the study may cause serious injury when those trees are cut. Partially exposed stakes may puncture vehicle tires or become a tripping hazard. Therefore, all markers should be collected and removed after surveying to reduce hazardous situations and unsightly litter. 


\section{Recording}

Quality notes, photographs, and video of high-water marks will ensure that useful data about the marks are available weeks or years after the search is complete. The notes, photographs, and video help field crews locate the flagged high-water marks if the survey is completed at a later date and provide a permanent record if the accuracy or application require further analysis.

Typically, field notes will include a site sketch of all high-water marks, or the marks will be noted on a printed or electronic map or on an overhead photograph of the area. In addition, close-up photographs or video should show each high-water mark individually. A small dry-erase board can be used to save information about the mark within a photograph (fig. 37). Wide-angle photographs or videos place high-water marks in local context for easier recovery and document the roughness of ground surface at the time of the flood for use in indirect measurements and modeling. Geotagging is also available on many video devices for storing location data with the images. While onsite, note and photograph any large obstructions that would have altered the flow through the reach, especially those in culverts or bridge contractions.

For each high-water mark, paper or electronic notes should list a unique identifier; the type of mark (for example, seed line or debris snag); the uncertainty of the mark; the approximate location; and any comments or observations about landowners, hazards, or nearby landmarks. Handheld GPS can be used to collect horizontal location data for each mark as well. Printed and electronic forms are available within the USGS to assist the hydrographer with note taking (fig. 38). Note that some information on this form might not be collected at the time of flagging if a survey crew will come in later to collect the detailed location and elevation data. An example form is posted for download with the electronic version of this manual.

The USGS has developed an online system (http://water. usgs.gov/floods/FEV/) to efficiently collect and disseminate high-water mark data (U.S. Geological Survey, 2015a). This system also contains storm-tide data from submersible pressure transducers for coastal and riverine events and associated metadata, including location, photographs, and notes, which can be accessed using the online map interface or search tool. Collected high-water mark data should be entered into the system from field notes as soon as practical after collection. Alternatively, hydrographers can save time by entering

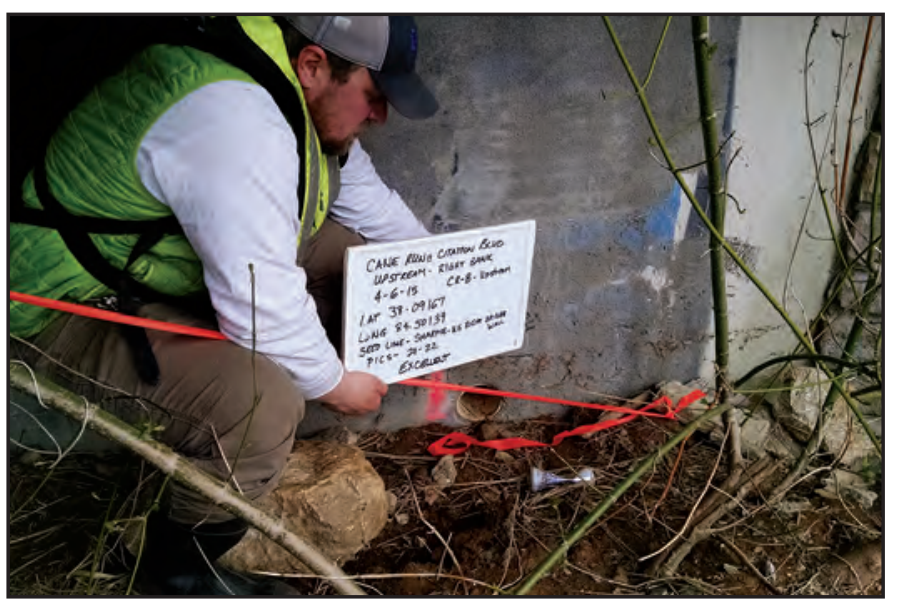

Figure 37. A hydrographer providing a written description of a flagged high-water mark using a white board. Photograph by Brian Moore.

preliminary and final surveyed high-water mark data directly into the system from a connected field device.

In addition to recording high-water mark data, field crews can save time and resources by using a surveyor's total station or GNSS instruments to survey and plot high-water marks during the search visit. Where practical, these surveys should include known reference mark elevations (typically North American Vertical Datum of 1988 [NAVD 88]) using a vertical level circuit. Surveying at the time of the search allows hydrographers to estimate the approximate water surface, judge the usefulness of the data collected, and make adjustments or additional observations as needed. Final surveys of the data should be made to a vertical precision of 0.01 foot to produce satisfactory results for indirect streamflow measurements or peak verification of USGS streamgages.

Flood inundation models make extensive use of Lidar datasets, and lidar technology is gaining increased use for recording individual high-water events. Terrestrial or aerial lidar units are positioned in an area of interest to scan and store the three-dimensional topography of the area. If clear sight lines from the lidar unit to the high-water marks are present, special markers or reflectors can be used during the scan to identify the location and elevation of high-water marks, which will be recorded within the scanned results. Alternatively, the marks may be surveyed with conventional or GNSS equipment and then combined with the lidar data (Justin Minear, U.S. Geological Survey, written commun., 2015). 
$\boldsymbol{A}$

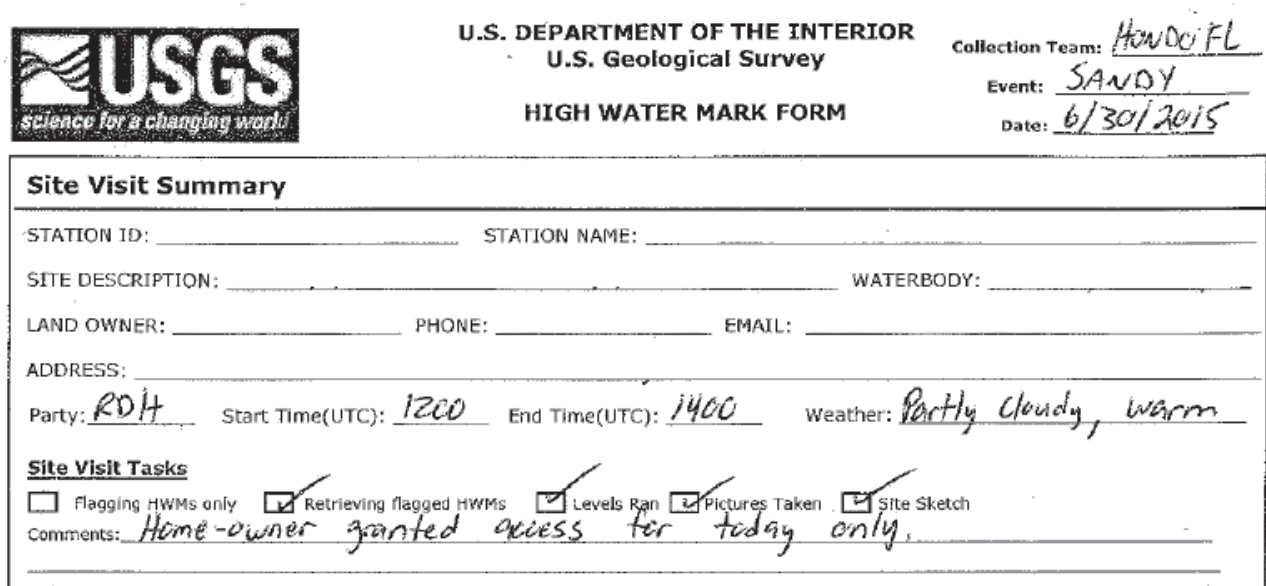

\section{Datum}

Horizontal daturn: WG584 How was it determined: Aandhe ld ifPS vertical datum: 1NAVDS8 How was it determined. Guss campaign performed and $C M$ installed near home. Type of "on-site" Objective Point used to determine HWM elevation(NGSBM, RM, RP): RM Elevation: $5,100 \mathrm{ft}$ Name(If NGSBM, PID/DES): RM/ Description: Chiseled sq. on seawall lacated comments: apfrox. $30 \mathrm{ft}$. Worth of front dear of home.

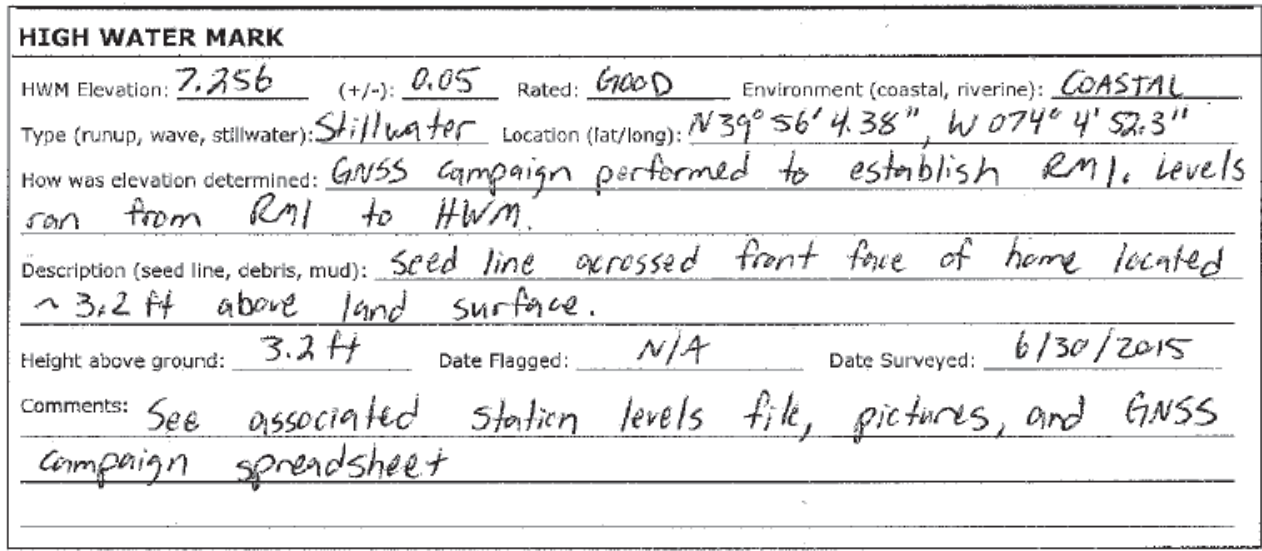

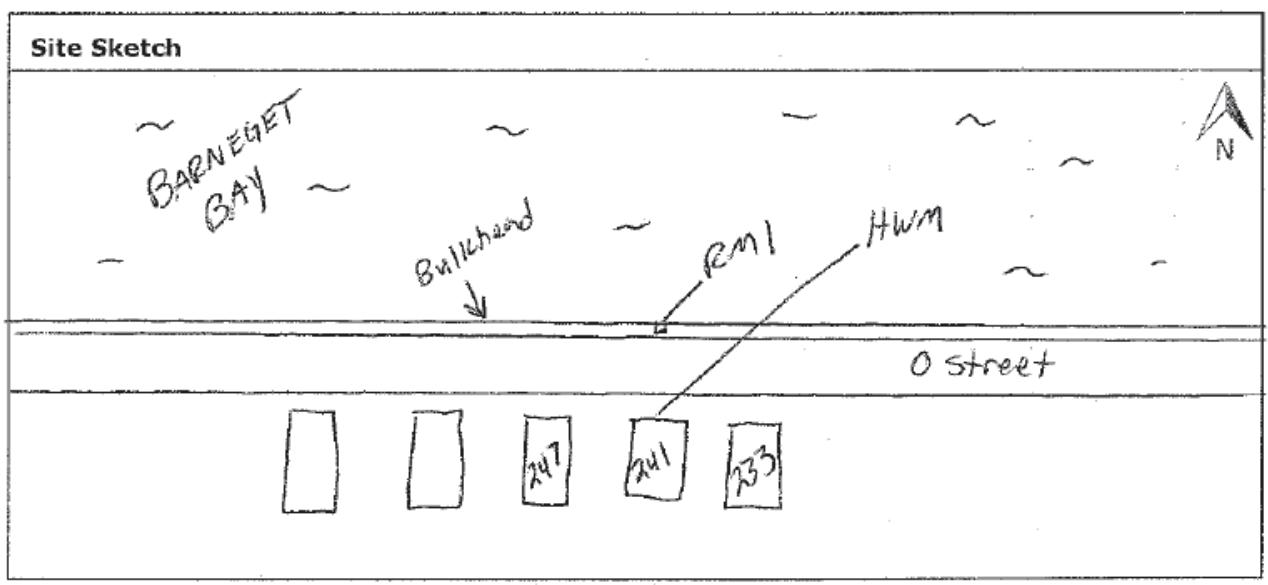

Figure 38. An example of $A$, a paper field form for recording high-water marks and $B$, an electronic form for recording high-water marks in an online system. 
Site

Site Description:

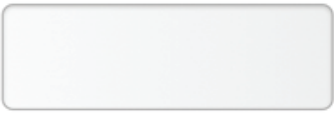

- Dec Deg DMS

Latitude:

Click here to populate address Lookup Address
fields:

Horizontal Datum:

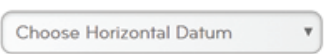

Horizontal Collection Method

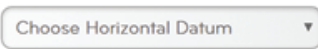

Waterbody: ${ }^{*}$

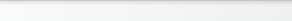

Address:

City:

State:

Zip:

County:

Station ID for USGS gage:

Station ID for NOAA gage:

Other Station ID:

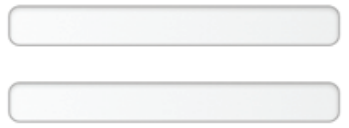

$\checkmark$

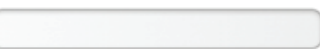

$\checkmark$

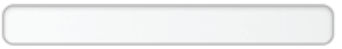

Please add details in the Site Descrip

Objective Point

Type:

Name: ${ }^{*}$

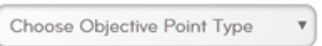

Vertical Datum

Choose Vertical Datum

Vertical Collection Method: Choose Vertical Collection Meth V

Description: *

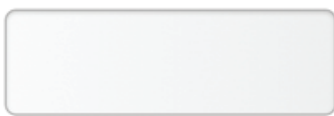

Uncertainty:

- +l- $\mathrm{ft} \bigcirc+/-\mathrm{cm}$

DR Unquantified

Control Identifier:

Add New Identifier

Quality:

- ft $\bigcirc$ meter

Elevation:

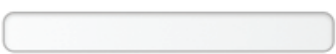

Objective Point Notes:

Choose an OP Quality $\checkmark$

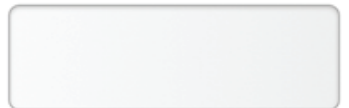

Date Established:

$2 / 25 / 2016$

HWM

HWM Type: *

Choose a HWM Type v

Surveyed Elevation (ft)

Vertical Datum:

Choose Vertical Datum

HWM Quality: *

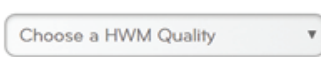

0.05 Excellent

0.1 Good

$0.2 \quad$ Fair

0.4 Poor

0.40 V. Poor

v

Height above ground (ft):

Flagged Date:

Surveyed Date:

Vertical Collection Method:

Choose a Vertical Collection Me v

Marker:

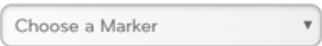

HWM Notes:

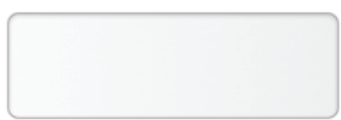

Stillwater Location?

Yes $\bigcirc$ No

Figure 38. An example of $A$, a paper field form for recording high-water marks and $B$, an electronic form for recording high-water marks in an online system.-Continued 


\section{Best Practices-Developing an Eye for Good High-Water Marks and Avoiding Pitfalls}

Searching for recent high-water marks requires an eye for detail that is best developed through field practice. Experienced hydrographers agree on several tips for improving the likelihood of identifying high-quality marks:

1. Safety first-Although many high-water marks are surveyed after dangerous floods have receded, floods and storms that create high-water marks may leave behind unstable structures, broken debris with sharp edges, damaged power lines, and unstable roads and footpaths. Hydrographers should always beware of lingering dangers associated with the flood, even after the event has passed. Floods often transport hazardous chemicals or fouled waters from urban or farm-related sewage systems, and polluted water may linger in streams or nearby pools in the landscape after the flood has receded. Careful attention to odors, proper handwashing, and cleaning of equipment will guard against risk of illness in this type of fieldwork. Floods also have a tendency to drive wildlife upward from the flood plain to whatever structures or shrubbery is available to escape the rising waters. Figure 39 shows a debris pile sharing a tree with a creature that may not welcome an unobservant hydrographer. A variety of hazards that are present during and after a flood are shown in figure 40.

2. Respond quickly - Most high-water marks are perishable and fragile and are likely to be disturbed, degraded, or destroyed by natural forces or cleanup efforts. The most important success factor when documenting high-water marks from recent events is to identify the marks before they change or disappear.
3. Look up -As floodwaters recede, secondary events may form multiple high-water marks below the highest mark (fig. 41). Sometimes, a lower, secondary mark is the first mark noticed, especially in coastal areas. Developing a habit of thoroughly checking above each high-water mark will improve the likelihood that the peak mark has been identified.

4. Stand back-A wider view may show patterns that were invisible up close, which is especially true with mud lines in low brush and foliage. Localized slumps in cut lines and debris lines may also be placed in context by observing the lines from a distance. See the "Paria River, Arizona" narrative for a detailed example. Looking through a surveyor's hand level from the elevation of a trusted high-water mark can aid in identifying or verifying other high-water marks. Tying temporary flagging to preliminary marks also helps to visualize the high-water line when stepping back. In addition, check structures for evidence of shifting or settling that may have been caused by the floodwaters (fig. 42). Shifting increases the uncertainty of the high-water mark elevation because determining the position of the structure at the moment when the marks were made may be impossible.

5. Visualize the flood - Observe the channel and imagine the water at the peak stage. Try to visualize how the water would have needed to behave to create the observed high-water marks. For overbank flows, try to pinpoint where the water's edge met the ground and look for verifying high-water marks; flows near the edges tend to be more tranquil and leave better marks. In confined channels such as deep canyon streams, look for reaches that are as uniform as possible and locate areas where floodwaters were completely confined to the main channel. Beware of roadways that may have interfered with flow or provided side channels with false highwater marks. Also, note the obstructions that could have impeded flow and the channel bends that could have superelevated the water surface.

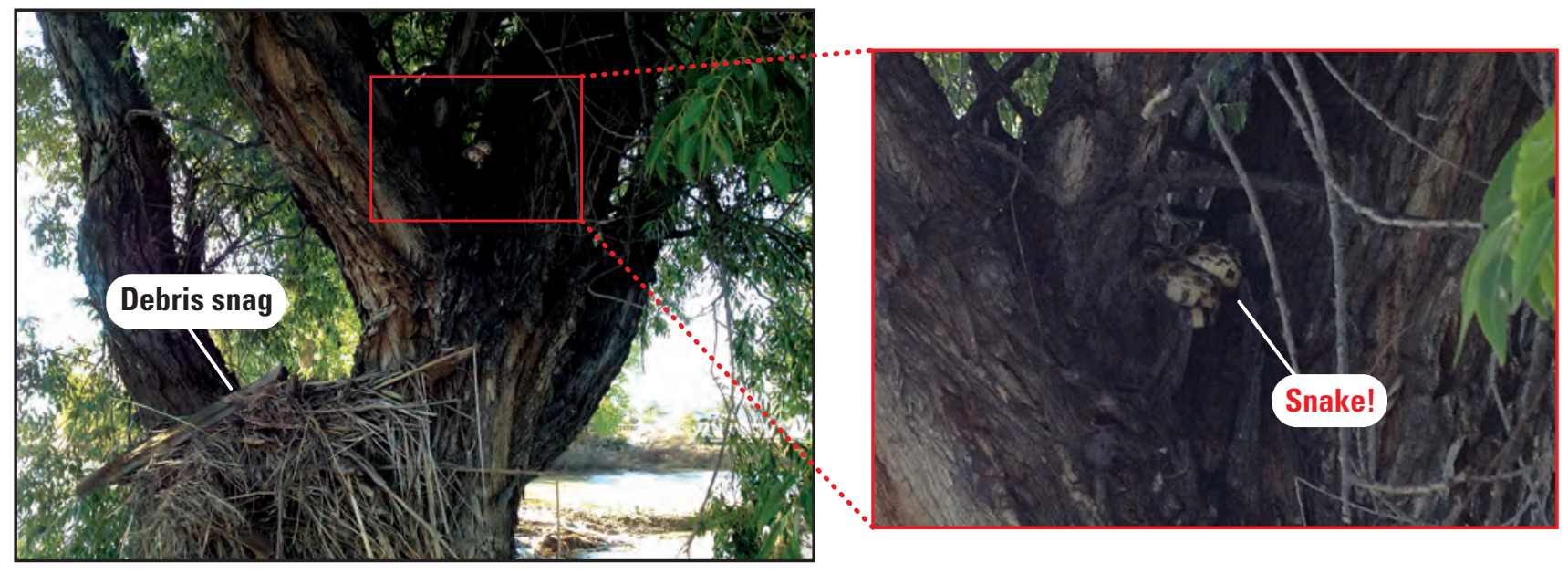

Figure 39. A debris pile in a tree with a snake napping in an upper branch. 


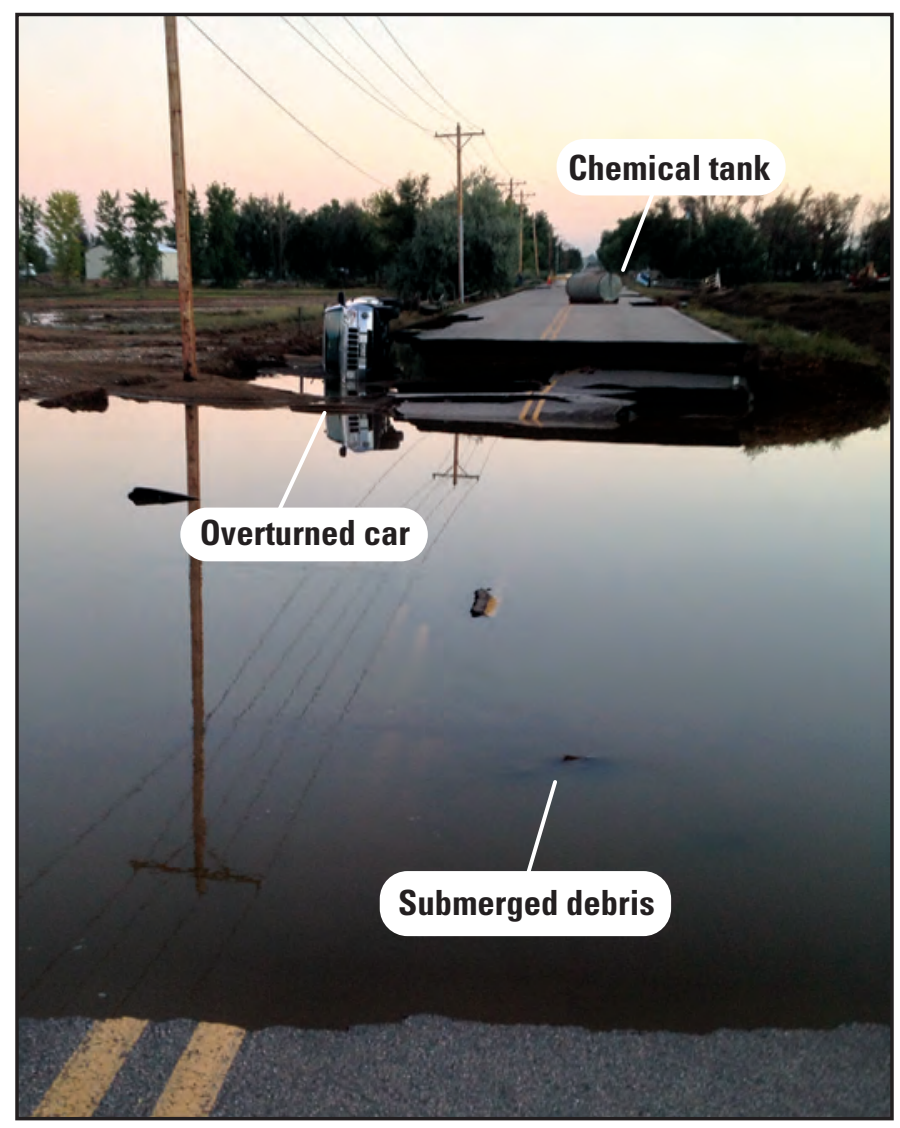

Figure 40. A road washout just downstream from a livestock farm on St. Vrain Creek, Colorado. This photograph shows a few hazards associated with flooding, which include the chemical tank that has floated away from its mooring and a vehicle that is overturned; the driver likely failed to see the washed-out road because of high floodwaters.

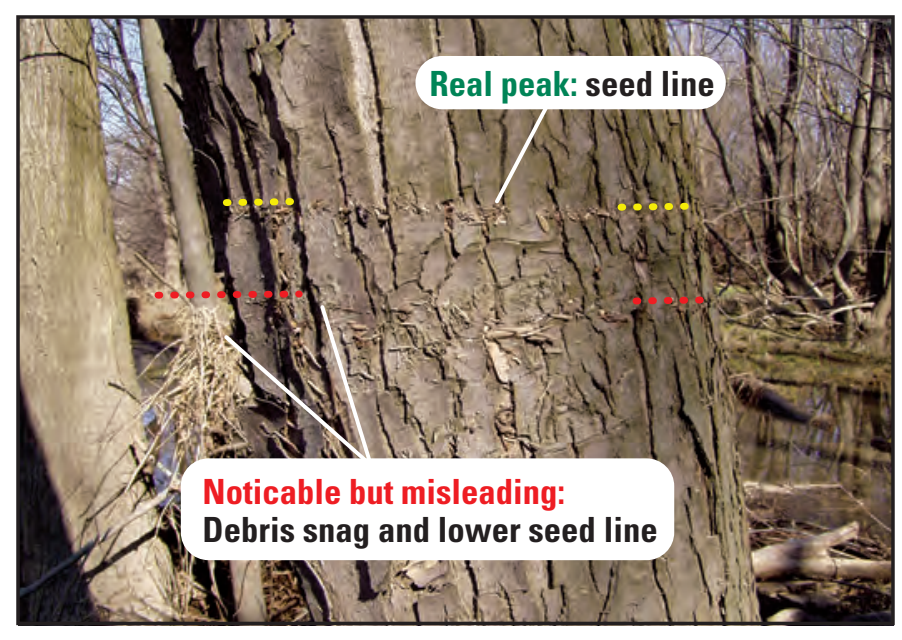

Figure 41. A debris snag and two seed lines. The debris snag on the left side of the trunk may have led the hydrographer to the lower seed line, but a quick glance upward reveals the peak highwater mark.

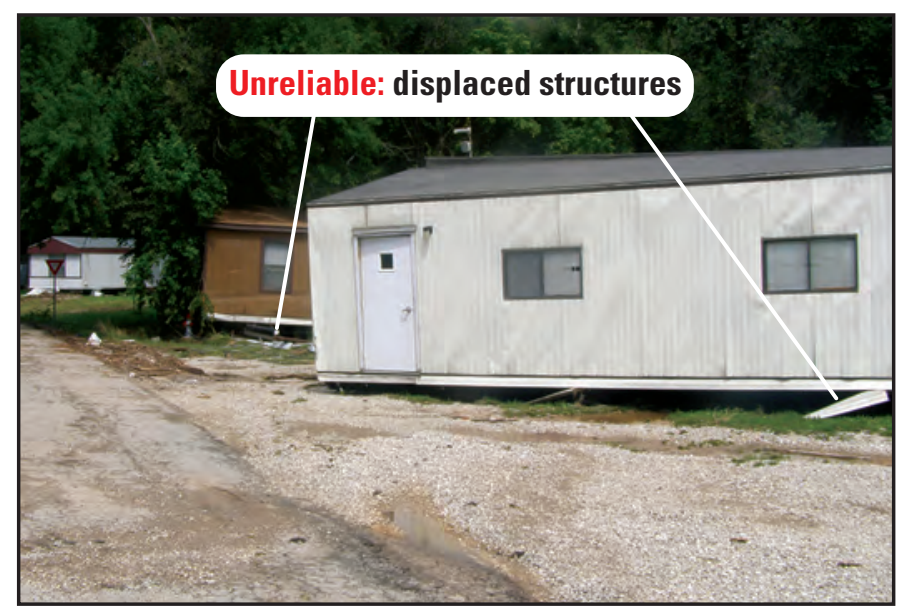

Figure 42. Structures with high-water marks that have likely moved during the flood, making peak water surface uncertain. Photograph by Paul Rydlund.

6. Hunt for hidden clues - Look for still-water locations such as ineffective flow areas or the interiors of enclosures and structures. These areas often have the best high-water marks because they collect finer debris in thin lines. Although larger debris piles may not make high-quality high-water marks, the piles may lead the hydrographer to better high-water marks nearby, or the piles may create slack water conditions along a bank where good seed lines may form, as discussed in the "Salcha River, Alaska" narrative. Pay attention to small enclosures, such as utility boxes. A fair mark on the outside of a building can correspond to an excellent mark inside an enclosure as shown in figure 43. However, recognize that structures with weak hydraulic or atmospheric connections may fill too slowly to reflect the outside peak water surface, as discussed in the "Cameron, Louisiana" narrative. Enclosed areas can also preserve marks from weather and other disturbances. Even if rain washes out most high-water marks before a field crew arrives, suitable marks may still exist if they are shielded overhead by tree canopies, bridge decks, rooftops, and other structures.

7. Think ahead-Always hunt for high-water marks with the end purpose in mind. Knowing the application of the data is essential to collecting the necessary quantity of marks from the most useful locations and ensuring sufficient water surface information for peak verification, indirect streamflow measurement, flood inundation studies, model calibration, or other applications that will follow. Hydrographers searching for high-water marks for indirect measurements or coastal surge campaigns should be well-versed in those methods, or they should search for high-water marks under the guidance of an experienced hydraulic modeler. When identifying highwater marks for indirect streamflow measurements, an 
immediate partial survey of those marks will help to detect poorly qualified reaches. These partial surveys may save considerable time by avoiding unworkable full geometric surveys of reaches that have insufficient fall or other unfavorable conditions that prevent a good measurement. A photograph showing a plot of high-water marks that was created in the field before beginning a full cross-section survey for an indirect streamflow measurement is shown in figure 44. If time does not allow for a full cross-section survey, an immediate high-water mark survey may be needed nonetheless to preserve the water surface elevation data, especially in urban areas where cleanup crews may destroy high-water marks and USGS markers. See the "St. Vrain Creek, Colorado" narrative for an example.
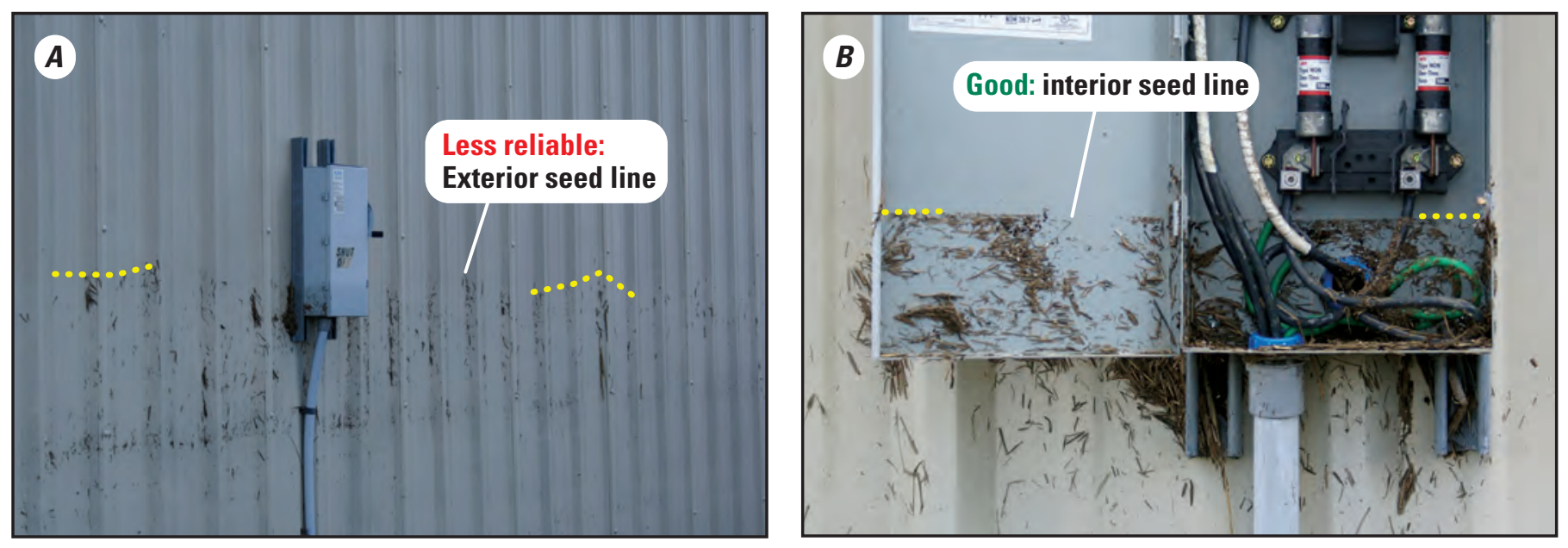

Figure 43. Seed lines $A$, formed on the outside of a structure and $B$, inside an enclosure attached to the structure. Although the exterior seed line was not a high-quality high-water mark, it led the hydrographer to the excellent seed line inside the utility box. Photograph by Aub N. Ward.

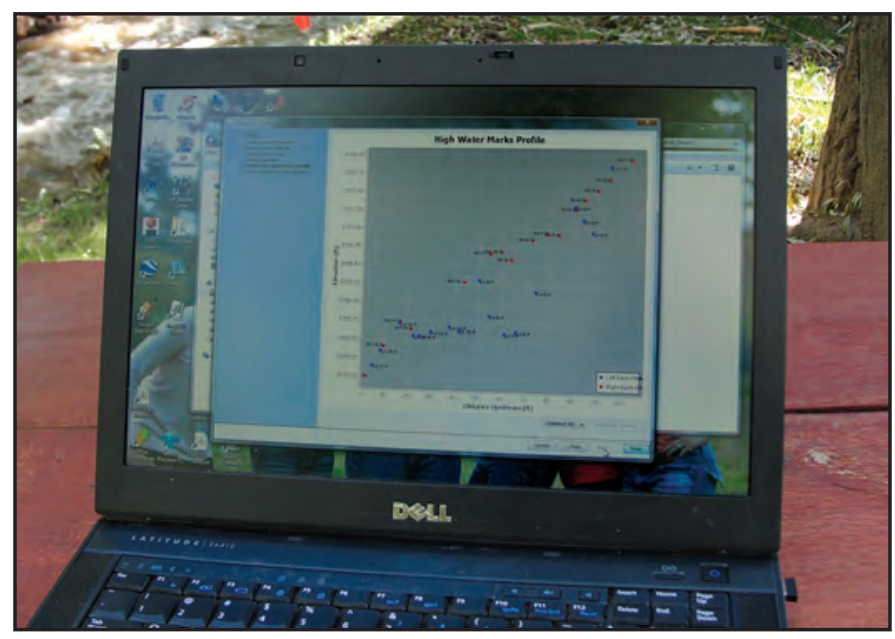

Figure 44. A plot of high-water marks created in the field. 


\section{References Cited}

Association of State Floodplain Managers, 2014, Strategies to establish flood frequencies associated with flood event high water marks, 50 p., accessed August 8, 2015, at http:// www.floods.org/ace-files/projects/asfpm_hwm report final_201406.pdf.

Baker, V.R., 1987, Paleoflood hydrology and extraordinary flood events: Journal of Hydrology, v. 96, nos. 1-4, p. 79-99.

Baker, V.R., and Kochel, R.C., 1988, Flood sedimentation in bedrock fluvial systems, in Baker, V.R., Kochel, R.C., Patton, P.C., eds., Flood geomorphology: New York, John Wiley and Sons, p. 123-137.

Baker, V.R., Webb, R.H., and House, P.K., 2002, The scientific and societal value of paleoflood hydrology, in House, P.K., Webb, R.H., Baker, V.R., Levish, D.R., eds., Ancient floods, modern hazards - Principles and applications of paleoflood hydrology: Washington, D.C., American Geophysical Union, Water Science and Application Series, v. 5, p. 127-146.

Benito, G., Sopeña, A., Sánchez-Moya, Y., Machado, M.J., and Pérez-González, A., 2003, Palaeoflood record of the Tagus River (Central Spain) during the Late Pleistocene and Holocene: Quaternary Science Reviews, v. 22, nos. 15-17, p. $1737-1756$.

Benito, G., and Thorndycraft, V.R., 2005, Palaeoflood hydrology and its role in applied hydrological sciences: Journal of Hydrology, v. 313, p. 3-15.

Benson, M.A., and Dalrymple, Tate, 1967 [1984], General field and office procedures for indirect measurements: U.S. Geological Survey Techniques of Water-Resources Investigations, book 3, chap. Al, $30 \mathrm{p}$. [Also available at http://pubs.usgs.gov/twri/twri3-a1/.]

Bodhaine, G.L., 1968 [1982], Measurement of peak discharge at culverts by indirect methods: U.S. Geological Survey Techniques of Water-Resources Investigations, book 3 , chap. A3, 60 p. [Also available at http://pubs.usgs.gov/twri/ twri3-a3/.]

Carter, Rebecca, 2002, END InSight—Floods in the Southwest: Tucson, Ariz, University of Arizona, CLIMAS, the Climate Assessment for the Southwest Project, Institute for the Study of Planet Earth, vol. 1, no. 3, p. 1-3, accessed on September 18, 2015, at http://www.climas.arizona.edu/sites/ default/files/pdf2002septfloods.pdf.

Dalrymple, Tate, and Benson, M.A., 1967 [1988], Measurement of peak discharge by the slope-area method: U.S. Geological Survey Techniques of Water-Resources Investigations, book 3, chap. A2, 12 p. [Also available at http://pubs.usgs.gov/twri/twri3-a2/.]
Dietrich, J.C., Westerink, J.J., Kennedy, A.B., Smith, J.M., Jensen, R.E., Zijlema, M., Holthuijsen, L.H., Dawson, C., Luettich Jr., R.A., Powell, M.D.; Cardone, V.J., Cox, A.T., Stone, G.W., Pourtaheri, H., Hope, M.E., Tanaka, S., Westerink, L.G., Westerink, H.J., Cobell, Z., 2011, Hurricane Gustav (2008) wave and storm surge-Hindcast, synoptic analysis, and validation in southern Louisiana: Monthly Weather Review, v. 139, no. 8, p. 2488-2522. [Also available at http://dx.doi. org/10.1175/2011MWR3611.1.]

Ely, L.L. and Baker, V.R., 1985, Reconstructing paleoflood hydrology with slackwater deposits - Verde River, Arizona: Physical Geography, v. 6, no. 2, p. 103-126.

Gary, M.R., McAfee, R., and Wolf, C.L., eds., 1972, Glossary of Geology: American Geological Institute, Washington, D.C., 805 p.

Harden, T.,M., O'Connor, J.E., Driscoll, D.G., and Stamm, J.F., 2011, Flood-frequency analyses from paleoflood investigations for Spring, Rapid, Boxelder, and Elk Creeks, Black Hills, western South Dakota: U.S. Geological Survey Scientific Investigations Report 2011-5131, 136 p.

Hope, M.E., Westerink, J.J., Kennedy, A.B., Kerr, P.C., Dietrich, J.C., Dawson, C., Bender, C.J., Smith, J.M., Jensen, R.E., Zijlema, M., Holthuijsen, L.H., Luettich Jr., R.A., Powell, M.D., Cardone, V.J., Cox, A.T., Pourtaheri, H., Roberts, H.J., Atkinson, J.H., Tanaka, S., Westerink, H.J., Westerink, L.G., 2013, Hindcast and Validation of Hurricane Ike (2008) Waves, Forerunner, and Storm Surge: Journal of Geophysical Research - Oceans, v. 118, no. 9, p. 4424-4460. [Also available at http://dx.doi.org/10.1002/ jgrc.20314.]

Hosman, K.L., Ely, L.L., and O'Connor, J.E., 2003, Holocene paleoflood hydrology of the Lower Deschutes River, Oregon, in O'Connor, J.E., and Grant, G.E., eds., A Peculiar River-Geology, Geomorphology, and Hydrology of the Deschutes River, Oregon: Water Science and Application Series, v. 7, American Geophysical Union, Washington, D.C., p. 267-293.

Hulsing, Harry, 1967 [1968], Measurement of peak discharge at dams by indirect methods: U.S. Geological Survey Techniques of Water-Resources Investigations, book 3, chap. A5, 29 p. [Also available at http://pubs.usgs.gov/twri/twri3-a5/.]

Jarrett, R.D., and England J.F. Jr., 2002, Reliability of paleostage indicators for paleoflood studies, in House, P.K., Webb, R.H., Baker, V.R., and Levish, D.R., eds., Ancient floods, modern hazards - Principles and applications of paleoflood hydrology: Washington, D.C., American Geophysical Union, Water Science and Application Series, v. 5, p. 91-109.

Kochel, R.C., and Baker, V.R., 1982, Paleoflood hydrology: Science, v. 215, no. 4531, p. 353-361. 
Kochel, R.C., Baker, V.R., and Patton, P.C., 1982, Paleohydrology of southwestern Texas: Water Resources Research, v. 18 , no. 4 , p. $1165-1183$.

Kraeer, Kim; Van Essen-Fishman, Lucy; and Saxby, Tracey, 2015, Illustrations from the IAN Image and Video Library: Integration and Application Network, University of Maryland Center for Environmental Science, accessed January 4, 2016, at http://ian.umces.edu/imagelibrary/.

Langbein, W.B., and Iseri, K.T., 1960, General introduction and hydrologic definitions: U.S. Geological Survey Water Supply Paper 1541-A, 29 p.

Matthai, H.F., 1967 [1976], Measurement of peak discharge at width contractions by indirect methods: U.S. Geological Survey Techniques of Water-Resources Investigations, book 3, chap. A4, 44 p. [Also available at http://pubs.usgs. gov/twri/twri3-a4/.]

McCord, V.A, 1996, Fluvial process dendrogeomorphology-Reconstruction of flood events from the southwestern United States using flood-scarred trees, in Dean, J.S., Meko, D.M, Swetnam T.W. eds., Tree rings, environment and humanity: Tucson, Ariz., Radiocarbon Special Issue, p. 689-699.

National Oceanic and Atmospheric Administration, 2015, National Ocean Service, Ocean Facts Web site, accessed Nov. 13, 2015, at http://oceanservice.noaa.gov/facts/stormsurge-stormtide.html.

O'Connor, J.E., Atwater, B.F., Cohn, T.A., Cronin, T.M., Keith, M.K., Smith, C.G., and Mason, R.R., 2014, Assessing inundation hazards to nuclear powerplant sites using geologically extended histories of riverine floods, tsunamis, and storm surges: U.S. Geological Survey Scientific Investigations Report 2014-5207, 66 p. [Also available at: http:// dx.doi.org/10.3133/sir20145207.]

O’Connor, J.E., Ely, L.L., Wohl, E.E., Stevens, L.E., Melis, T.S., Kale, V.S., and Baker, V.R., 1994, A 4500-year record of large floods on the Colorado River in the Grand Canyon, Arizona: The Journal of Geology, v. 102, no. 1, p. 1-9.

O’Connor, J.E., Webb, R.H., and Baker, V.R., 1986, Paleohydrology of pool-and-riffle pattern development: Boulder Creek, Utah: Bulletin of the Geological Society of America, v. 97 , p. $410-420$.

Pielke, R.A., Jr., Downton, M.W., and Barnard Miller, J.Z., 2002, Flood damage in the United States, 1926-2000-A reanalysis of National Weather Service estimates: Boulder, Colo., University Corporation for Atmospheric Research, 86 p, accessed January 4, 2016, at http://www.flooddamagedata.org/flooddamagedata.pdf.

Pierson, T.C., 2005, Distinguishing between debris flows and floods from field evidence in small watersheds: U.S. Geological Survey Fact Sheet 2004-3142, 4 p., accessed January 4, 2016, at http://pubs.usgs.gov/fs/2004/3142/.
Rantz, S.E., and others, 1982, Measurement and computation of streamflow-Volume 1, Measurement of stage and discharge, and Volume 2, Computation of discharge: U.S. Geological Survey Water-Supply Paper 2175, p. 1-631. [Also available at http://pubs.usgs.gov/wsp/wsp2175/.]

Rydlund, P.H., Jr., and Densmore, B.K., 2012, Methods of practice and guidelines for using survey-grade global navigation satellite systems (GNSS) to establish vertical datum in the United States Geological Survey: U.S. Geological Survey Techniques and Methods, book 11, chap. D1, 102 p., with appendixes. [Also available at http://pubs.usgs.gov/ $\mathrm{tm} / 11 \mathrm{~d} 1 /$.]

Sauer, V.B., and Turnipseed, D.P., 2010, Stage measurement at gaging stations: U.S. Geological Survey Techniques and Methods, book 3, chap. A7, 45 p. [Also available at http:// pubs.usgs.gov/tm/tm3-a $7 /$.

Sheffer, N.A., Enzel, Y., Benito, G., Grodek, T., Poart, N., Lang, M., Naulet, R., and Coeur, D., 2003, Historical and palaeofloods of the Ardeche River, France: Water Resources Research, v. 39, no. 12, p. ESG 7-1/7-13.

Sigafoos, R.S., 1964, Botanical evidence of floods and floodplain deposition: U.S. Geological Survey Professional Paper 485A, p. 35.

Thorndycraft, V.R., Benito, G., Rico, M., Sopeña, A., SánchezMoya, Y., and Casas, A., 2005, A long-term flood discharge record derived from slackwater flood deposits of the Llobregat River, NE Spain: Journal of Hydrology, v. 313, nos. 1-2, p. 16-31.

U.S. Geological Survey, 2015a, Flood event viewer-Providing hurricane and flood response data: U.S. Geological Survey, accessed July 30, 2015, at http://water.usgs.gov/ floods/FEV/.

U.S. Geological Survey, 2015b, Flood Resources Web site, accessed July 30, 2015, at http://water.usgs.gov/floods/ resources/iqm/.

Webb, R.H., and Jarrett, R.D., 2002, One-dimensional estimation techniques for discharges of paleofloods and historical floods, in House, P.K., Webb, R.H., Baker, V.R., and Levish, D.R., eds., Ancient floods, modern hazards-Principles and applications of paleoflood hydrology: Washington, D.C., American Geophysical Union, Water Science and Application Series, v. 5, p. 111-125.

Williams, G.P., and Costa, J.E., 1988, Geomorphic measurements after a flood, in Baker, V.R., Kochel, R.C., and Patton, P.C., eds., Flood geomorphology: New York, John Wiley and Sons, p. 65-77.

Yanosky, T.M., and Jarrett, R.D., 2002, Dendrochronologic evidence for the frequency and magnitude of paleofloods, in House, P.K., Webb, R.H., Baker, V.R., and Levish, D.R., eds., Ancient floods, modern hazards-Principles and applications of paleoflood hydrology: Washington, D.C., American Geophysical Union, Water Science and Application Series, v. 5, p. 77-89. 


\section{Glossary}

Note: Glossary definitions are from Langbein and Iseri (1960) or Gary and others (1972) whenever possible.

annual exceedance probability (AEP) The probability, or chance, of a flood of a given streamflow magnitude being equaled or exceeded in any given year. The probability can be expressed as a fraction, decimal, or percentage.

backwater Water that is retarded, backed up, or turned back in its course by an obstruction (such as a dam), an opposing current, or the movement of the tide. A flooded river or lake may become the controlling feature of an upstream tributary, temporarily changing its water surface slope or its stage-discharge relation while under backwater control.

channel morphology The study of channel patterns and channel geometry.

colluvium Loose, heterogeneous, and incoherent mass of soil material or rock fragments deposited chiefly by mass-wasting, usually at the base of a steep slope or cliff.

debris flow A sediment and water slurry capable of holding gravel-sized particles in suspension when flowing slowly or stopped, which can cause catastrophic damage from impact or burial (Pierson, 2005). Debris flows do not exhibit Newtonian fluid properties and cannot be measured using indirect measurement techniques designed for water flows.

discharge In its simplest concept discharge means outflow; therefore, the use of this term is not restricted as to course or location, and it can be applied to describe the flow of water from a pipe or from a drainage basin. Discharge in the United States is commonly reported in cubic feet per second ( $\mathrm{ft} 3 / \mathrm{s})$.

eddy A water current that is generally circular in motion.

flood An overflow or inundation that comes from a river or other body of water and causes or threatens damage.

fluvial Of or found in a river. gage height The height of the water surface above an established datum plane. Gage height and stage are often used interchangeably; however, gage height is more appropriate when used to indicate a reading on a gage. Gage height is usually expressed in feet and hundredths of a foot or in meters and hundredths or thousandths of a meter.

headwater (Or "head water" or "water head"). The water upstream from a structure, as behind a dam. Also, the source (or sources) and upper part of a stream (especially of a large stream or river), including the upper drainage basin; a stream from this source.

indirect streamflow measurement Forensic methods using data collected after the event to compute streamflow of a past flood (Benson and Dalrymple, 1984).

optically stimulated luminescence (OSL) dating A method of determining the length of time a mineral has been buried with naturally occurring radioactive isotopes. An OSL dating relies on the accumulation of free electrons derived from the decay of radioisotopes within structural defects in the crystal lattice of a mineral grain. The longer a mineral grain is exposed to a radiation source, such as being buried in sediment with radioactive isotopes, the more trapped electrons accumulate.

When a mineral grain is exposed to light, the electrons are stimulated and released from the crystal lattice. Under laboratory conditions, the number of electrons released can be measured and correlated to the amount of time the crystal has been buried, thus giving a burial age (Harden and others, 2011).

riparian Pertaining to the banks of a stream. slack water A portion of a stream that does not contribute to the downstream flow, often containing low-energy eddies. 
slope wash Soil and rock material transported down a slope by mass-wasting assisted by running water not confined to channels. See also colluvium.

stage The height of the water surface above an established datum plane. Stage and the term "gage height" are often used interchangeably. Stage is usually expressed in feet and hundredths of a foot or in meters and hundredths or thousandths of a meter.

stilling well An enclosed area of still water hydraulically connected to a stream channel, designed to mimic the stage of the stream but protected from waves, floating debris, and other surface disruptions.

stratigraphic Pertaining to rock layers (strata) and the study thereof.

streamgage A particular site on a stream where a record of streamflow is obtained.

streamflow The discharge that occurs in a natural channel. Although the term discharge can be applied to flow in a canal, the word streamflow uniquely describes the discharge in a surface stream course. Streamflow in the United States is commonly reported in cubic feet per second $\left(\mathrm{ft}^{3} / \mathrm{s}\right)$.

subcritical flow Water flow whose velocity is less than that of a long surface wave in still water.

supercritical flow Water flow whose velocity exceeds the velocity or propagation of a long surface wave in still water.

superelevation Water surface that is sloped higher at one bank and lower at the opposing bank, typically because of a bend in the stream.

tailwater (Or "tail water"). The water downstream from a structure, as below a dam.

turbidity The state, condition, or quality of opaqueness or reduced clarity of a fluid, due to the presence of suspended matter. 
Appendix 


\section{Appendix 1. Paleoflood High-Water Marks}

High-water marks left behind by old or even ancient floods, called paleoflood indicators, usually predate the systematic gaged record and support the field of "Paleoflood hydrology." Paleoflood hydrology, or flood geology, is the reconstruction of the magnitude and frequency of past floods using geological or botanical evidence (Kochel and Baker, 1982). Paleoflood evidence includes various geologic indicators (flood deposits and geomorphic features), flotsam deposits, and physical effects on vegetation. These indicators can provide information about the timing, magnitude, and frequency of historical flood events, particularly those from times or locations lacking direct measurements and observations.

Historical flood data, in turn, support modern-day flood hazard assessments and provide valuable information about the linkages among climate, land use, flood frequency, and channel morphology. Paleoflood studies also complement streamgage measurement programs by extending records of flooding beyond the gage record, improving the statistical analysis of annual exceedance probabilities and the ability to accurately assess hazard risk to critical infrastructure such as dams and power plants (O’Connor and others, 2014).
An important aspect of paleoflood studies is the recognition of physical evidence (and its limitations). This evidence can include some of the common high-water marks, such as mud, silt, and seed and debris lines; however, this type of evidence may only persist for a few weeks (in humid climates) to perhaps several years (in semiarid and arid climates; Williams and Costa, 1988). More typically, paleoflood studies rely on longer lasting evidence of peak flow stages, such as fine-textured flood sediment (slack water flood deposits), gravel and boulder bars, silt lines, erosion features (fig. 1-1; Baker, 1987; Baker and Kochel, 1988; Webb and Jarrett, 2002), and botanical evidence such as scars or deformities on riparian trees. Depending on the environment, some of these paleoflood indicators can persist for several millennia.

The availability of paleoflood evidence depends on local geologic and physiographic conditions, and on watershed conditions (O'Connor and others, 2014). The classic region for paleoflood studies has been the canyons of the American southwest, where sediment-laden rivers and bedrock channels with flanking nooks and crannies promote the preservation of flood deposits; some of the deposits are several thousand years old; however, work over the past 3 decades, as illustrated in the accompanying case studies, indicates that such studies are possible in many environments.

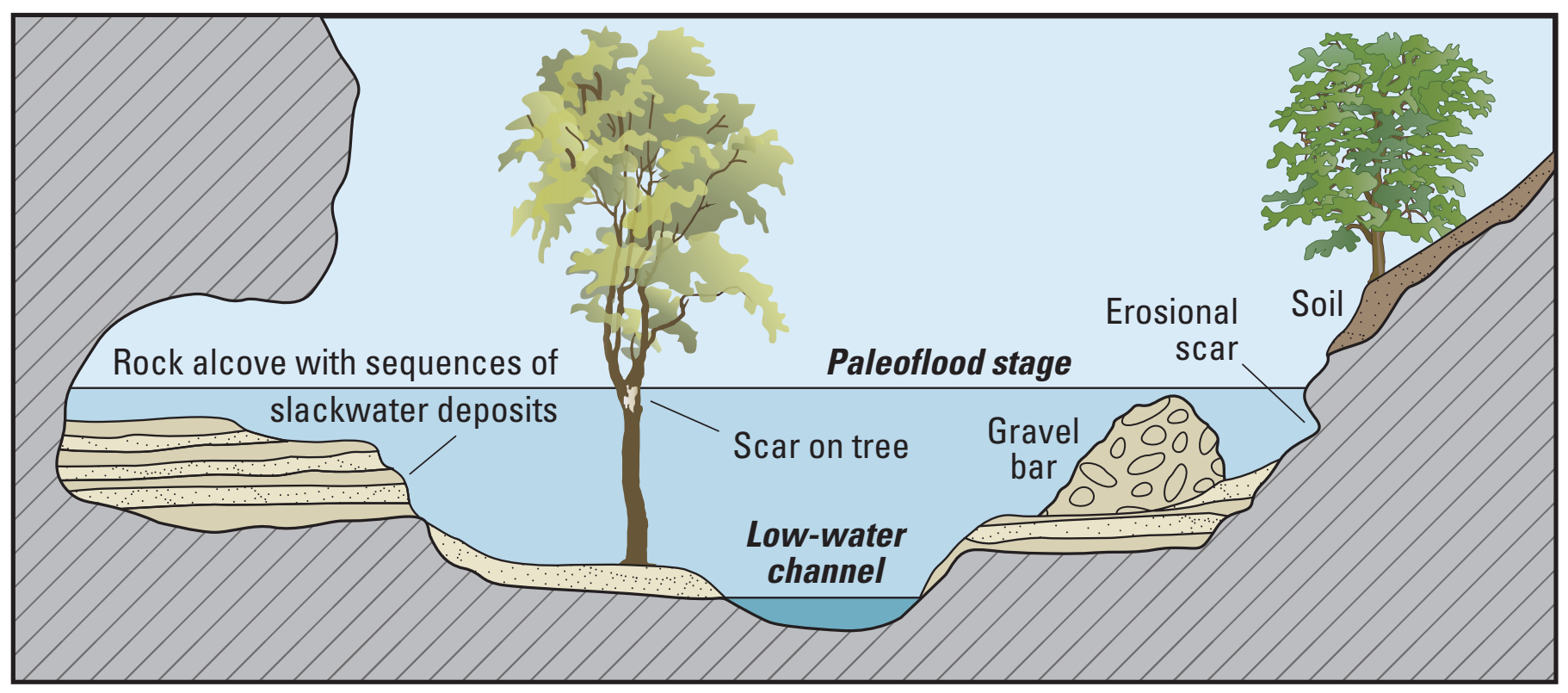

Figure 1-1. Types of geologic and biologic evidence left by floods. Modified from Carter, 2002; Kraeer and others, 2015. 


\section{Colorado River in the Grand Canyon, Arizona}

The Colorado River in the Grand Canyon is a near-ideal situation for creating and preserving paleoflood evidence. Before impoundment by Glen Canyon Dam near Lee's Ferry, Ariz., sediment-laden Colorado River floods built sand bars, canyon-flanking sand benches, and slack water deposits in tributary mouths and in alcoves carved in the canyon margins. The rock types exposed in the canyon include layered sedimentary rocks and massive limestones, creating abundant overhangs, alcoves, and small caves. A reach of extensive paleoflood evidence is the informally named Axehandle Alcove reach in the upper Grand Canyon, about 1.86 miles downstream from Lee's Ferry (O'Connor and others, 1994). At the reach, sequences of flood deposits are preserved in stacks in tributary mouths, under canyon overhangs, and in small crevices in the canyon wall.

To determine the flood history of the Axehandle Alcove reach, deposits were mapped and described, and material was collected for radiocarbon dating. Additionally, deposit elevations were surveyed and related to step-backwater modeling developed for the reach to provide minimum estimates of the peak streamflow of each flood (by assuming that peak stage was at least as high as emplaced deposits). This information provided a chronology of at least 15 large floods during the last 4,500 years, including an exceptional flood 1,600-1,200 years ago.

A particularly continuous silty sand layer caps many of the deposits and can be traced for several hundred yards along the canyon margin. Based on radiocarbon dating, continuity, and the layer's elevation and relatively fresh appearance, this deposit is inferred to be left by the Colorado River flood of 1884 , the largest flood in the gaged record. The analysis also confirmed the USGS published estimate for the 1884 peak flow (O’Connor and others, 1994).


Photographs of the Axehandle Alcove study site, Colorado River, Grand Canyon, Arizona, showing $A$, the primary stratigraphic site is within an alcove on the left canyon wall, with a large accumulation of slack water sediments in the tributary canyon mouth at right; $B$, slack water and local slope wash sediment accumulation, protected by overhanging ledge of Kaibab Limestone; $C$, deposit of laminated flood silt extracted from crevice. The elevation implies a streamflow of 14,000 cubic meters per second, much larger than the largest historical peak streamflows of the 1884 and 1921 floods; $D$, exposed stratigraphy of grey beds of silt and sand flood deposits, separated by red beds of pebbly sand and silt deposited by runoff from adjacent slopes; and $E$, silty flood deposits with mud-cracked caps. 


\section{Paleoflood Silt Lines}

As with all high-water marks, paleoflood indicators differ in their ability to reliably and accurately reflect the actual peak flood surface. The best, but rare, paleoflood indicators are silt lines, which are subhorizontal linear deposits of silt- and claysized particles traced along some portion of the bedrock canyon walls that provide clear evidence of maximum flood stage (fig. 1-2). Paleoflood silt lines are deposited as the floodwaters cover and, in places, percolate into bedrock valley margins (O'Connor and others, 1986). Sometimes paleoflood silt lines can be traced to nearby slack water deposits (described in the "Slack Water Deposits" section), which may be more likely to be datable by standard geochronologic approaches such as radiocarbon or optically stimulated luminescence dating (O'Connor and others, 2014).

\section{Slack Water Deposits}

The most complete paleoflood records generally result from the analysis of stratigraphic sequences of finegrained flood deposits in slack water and eddy environments (figs. 1-2, 1-3). Slack water flood deposits are fine-grained sedimentary deposits that accumulate from suspension during floods (Baker and others, 2002). Slack water sedimentation areas include flooded valley margins subject to eddies, back flooding, flow separation, and water stagnation during high stages. These areas include zones of channel widening, severe channel bends, obstacle hydraulic shadows where flow separation causes eddies, alcoves and caves in bedrock walls, backflooded tributary mouths and valleys, and the tops of high alluvial or bedrock surfaces that flank the channel (Kochel and others, 1982; Ely and Baker, 1985; Baker and Kochel, 1988; Benito and others, 2003; Hosman and others, 2003; Sheffer and others, 2003; Benito and Thorndycraft, 2005;

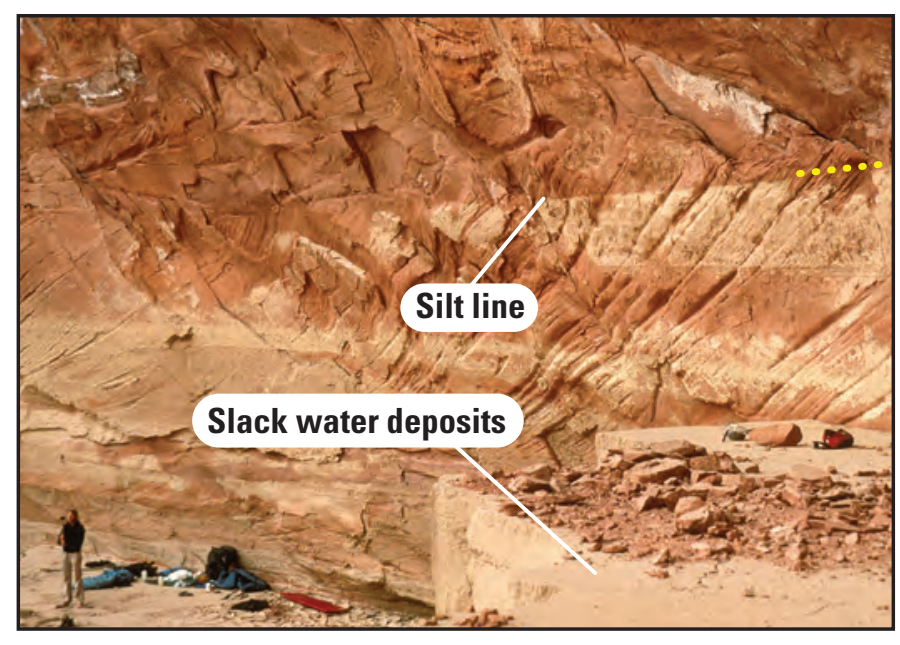

Figure 1-2. Silt lines and slack water sediment deposited in a dry alcove. The dry and protected environment results in wellpreserved flood evidence. Photograph by Robert Webb.
Thorndycraft and others, 2005). Diminished flow velocities in these areas promote rapid deposition of fine-grained suspended sediments. The resulting slack water flood deposits commonly contain sedimentary structures and textures reflecting flow energy, direction, and velocities (fig. 1-4). Because sedimentation occurred when the peak stage of the flood was at least as high as the resulting deposit, elevations of slack water deposits indicate the minimum elevation of flood surface, but not necessarily the peak. In the right environments, sequences of several flood deposits may accumulate, providing a record of multiple floods. Tracing recent flood deposits can lead hydrographers to paleoflood slack water deposits (Harden and others, 2011).

Some fluvial and geologic environments are particularly suitable for forming and preserving slack water deposits. In particular, rivers with high sediment loads flowing through narrow bedrock canyons are likely to create slack water deposits, particularly in bends, tributary junctions, and other backwater areas where flow separation creates zones of deposition. This evidence is best preserved where the deposits are protected from disturbance by vegetation, animals, and cultural activities and where weathering is inhibited. In general, arid environments aid preservation because of slower weathering and fewer disturbances by vegetation. Caves, alcoves, and rock overhangs also facilitate deposition and protection; therefore, river valleys or canyons formed in rock types such as ledgy sedimentary rocks, limestones, and marbles, commonly have paleoflood evidence.

Slack water paleoflood studies are discussed in each of the narratives included in this appendix that include the types of rivers for which paleoflood studies can be effective. The three studies rely primarily on slack water deposit records while indicating the diversity and types of environments and depositional records that can support paleoflood analysis. In each case, the stratigraphic record of flooding enabled more confident assessment of the annual exceedance probability of rare, high-magnitude floods.

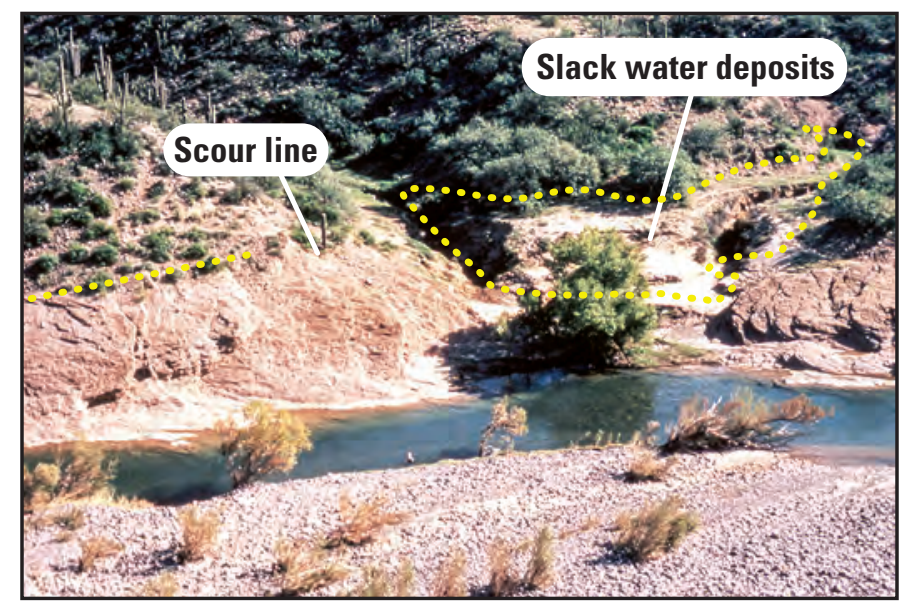

Figure 1-3. A scour line and slack water sediment accumulation in a small tributary junction flowing left to right. 


\section{Other Paleoflood Evidence}

Other paleoflood indicators, although less common, can be used to quantify past peak flows. Examples of other paleoflood indicators include high-level scour marks on valley-margin colluvium and soils (fig. 1-3); however, attributing the marks to a particular flood may be difficult (Webb and Jarrett, 2002). In high-gradient streams, coarse boulder

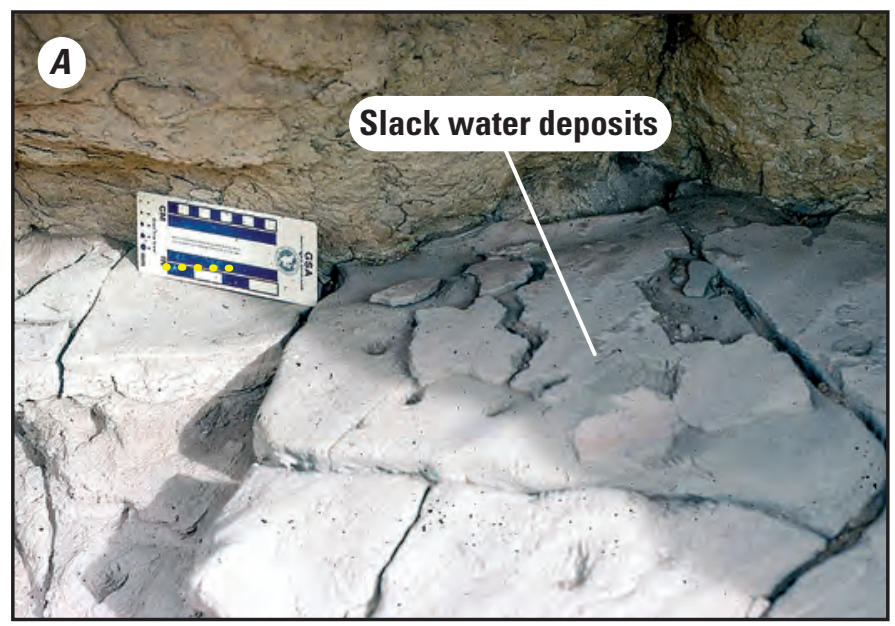

deposits are the most common large-flood deposits (Jarrett and England, 2002). Botanical flood evidence in riparian trees, such as scarring, sprouts from tilted stems, and eccentric ring growth (fig. 1-5; Sigafoos, 1964), can be used effectively for reconstructing regional flood magnitude and frequency (McCord, written commun, 1990; McCord, 1996; Yanosky and Jarrett, 2002).

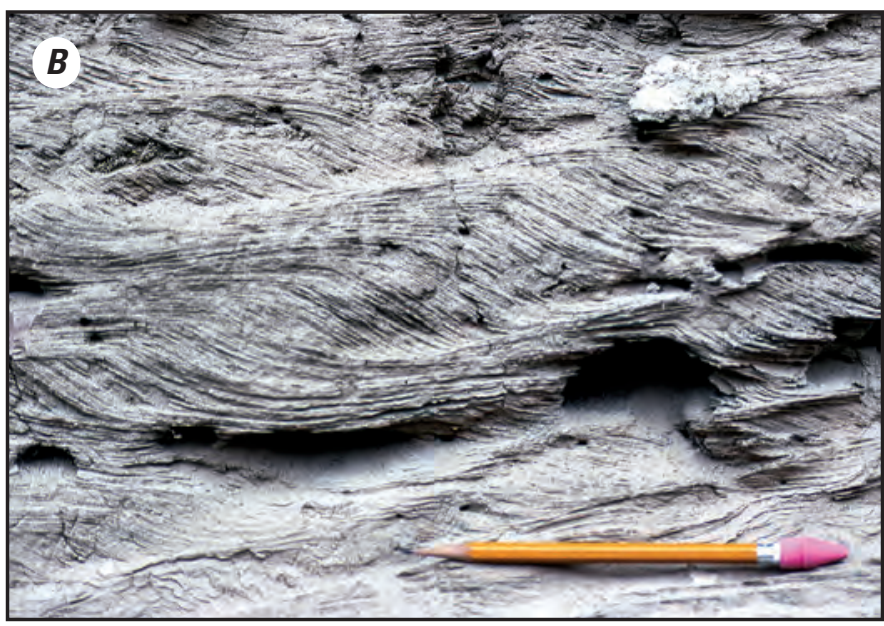

Figure 1-4. A, Silty flood deposits with mud-cracked caps that were deposited in a small alcove and $B$, the sedimentology of these deposits showing climbing ripple cross stratification, an indication of high rates of sedimentation by a current moving left to right.

Figure 1-5. Paleoflood evidence on trees: $A$, tree scars commonly form from battering by flood-borne driftwood; $B$, a recently sawn juniper tree, knocked down early in life, shows subsequent vertical sprout; and $C$, a cross section of the same juniper tree, showing eccentric growth starting at the time the tree was knocked down. Ring counting indicates the tree was likely knocked down by a large historic flood in 1861.

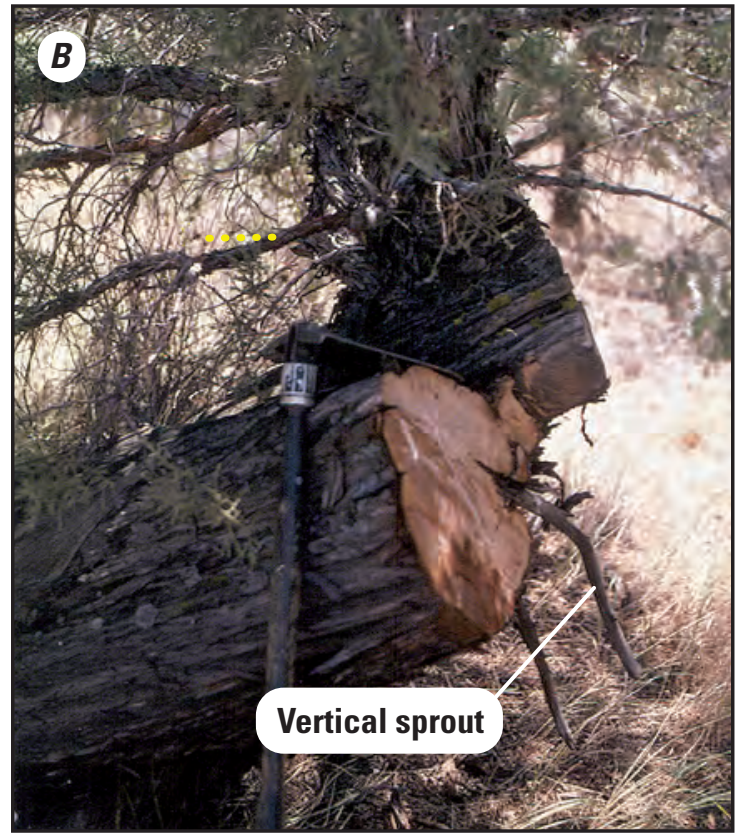

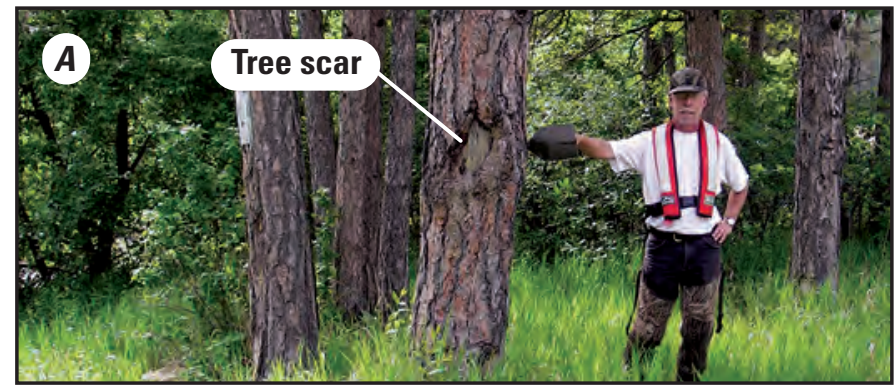

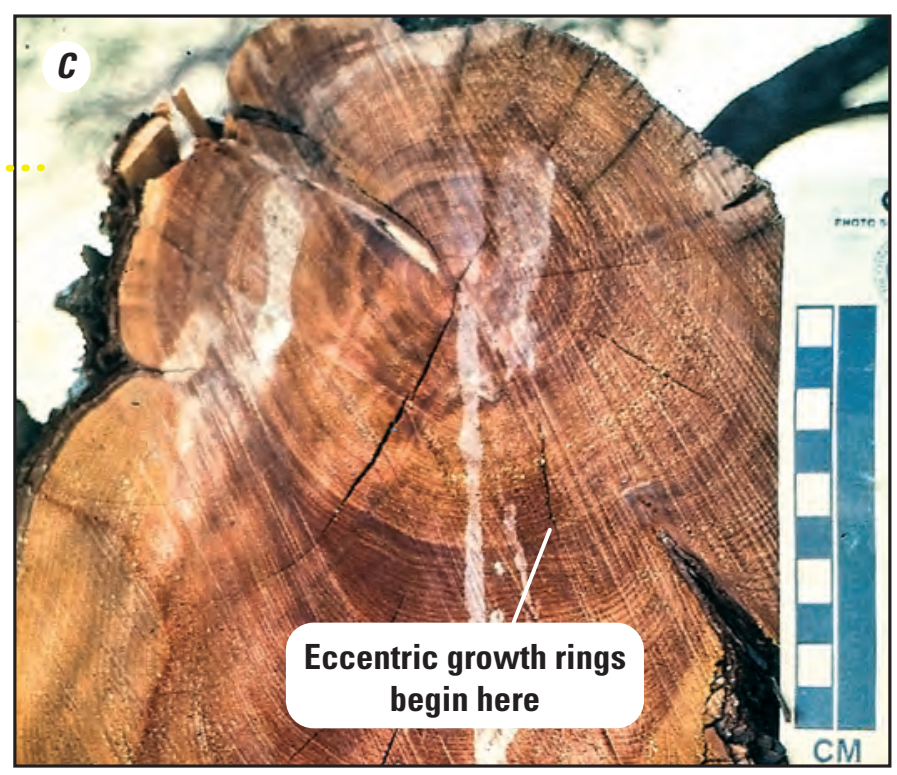




\section{Black Hills, South Dakota}

A recent paleoflood study in the eastern Black Hills, South Dakota, was motivated by challenging conditions for assessing flood frequency in the region (Harden and others, 2011). In particular, widespread flooding in June 1972 killed at least 238 people, illustrating a significant local flood hazard. Despite a gaged and historical flood record going back 60 years for most of the larger streams in the region, the 1972 flood is an outlier in a gaged record that does not serve as a reliable basis for estimating flood frequency. The need for more large event evidence prompted a paleoflood analysis to improve estimates of recurrence intervals for floods such as the 1972 flood.

The Black Hills streams are atypical paleoflood sites; most are small and steep, with drainage areas less than 386 square miles and as small as 37 square miles. However, the combination of granitic headwaters (which produce abundant sand) and downstream valleys incised into Paleozoic sandstones and limestones (which provide small caves and alcoves for accumulating and protecting flood deposits) have preserved long and useful paleoflood records for these streams (Harden and others, 2011). Tracing deposits of the 1972 floods helped identify paleoflood evidence for further investigation; digging through accumulations of 1972 slack water sediment commonly revealed several underlying layers of older flood sediment. Sediment accumulations in small alcoves and ledges above the 1972 deposits provide evidence of even larger floods.

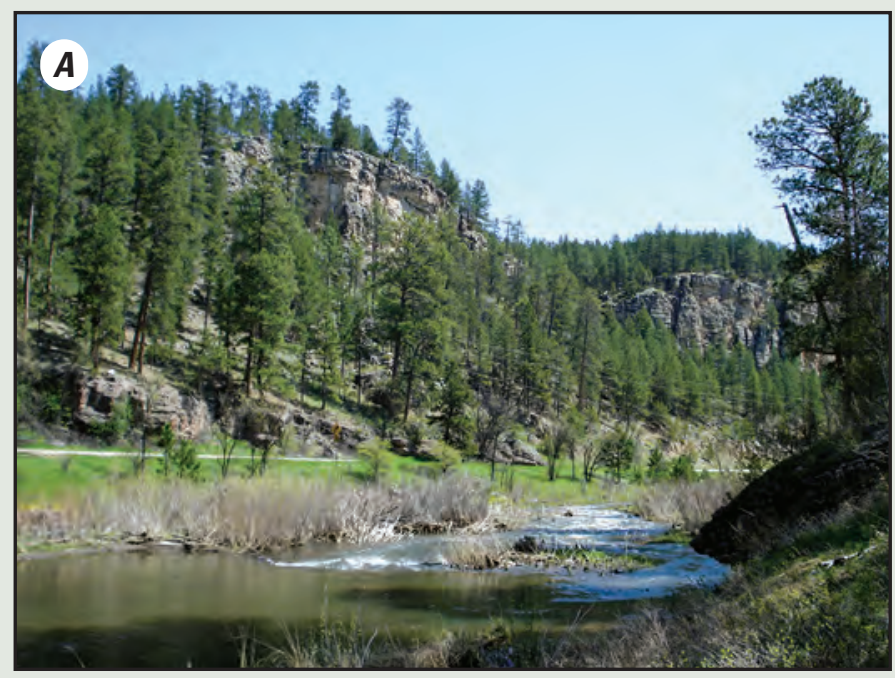

$A$, Boxelder Creek in the eastern Black Hills, South Dakota. $B$, Deposits along the valley margin of Spring Creek, S. Dak. Grey sandy flood deposits are separated by poorly sorted rockfall and slope wash. Radiocarbon dating indicates that the thicker, coarser sand deposit below the 1972 flood deposit was left about 700 years ago. $C$, Interpreted flood stratigraphy of Spring Creek, S. Dak. (Harden and others, 2011; cm, centimeter). Photograph $A$ by John Stamm.
The stratigraphic records at 29 individual study sites, supported by 99 radiocarbon and 11 optically stimulated luminescence (OSL) age determinations, indicate multiple paleofloods during the last 2,000 years. For some reaches, some of these floods were larger than the 1972 flood as indicated by deposit elevation, thickness, and texture.
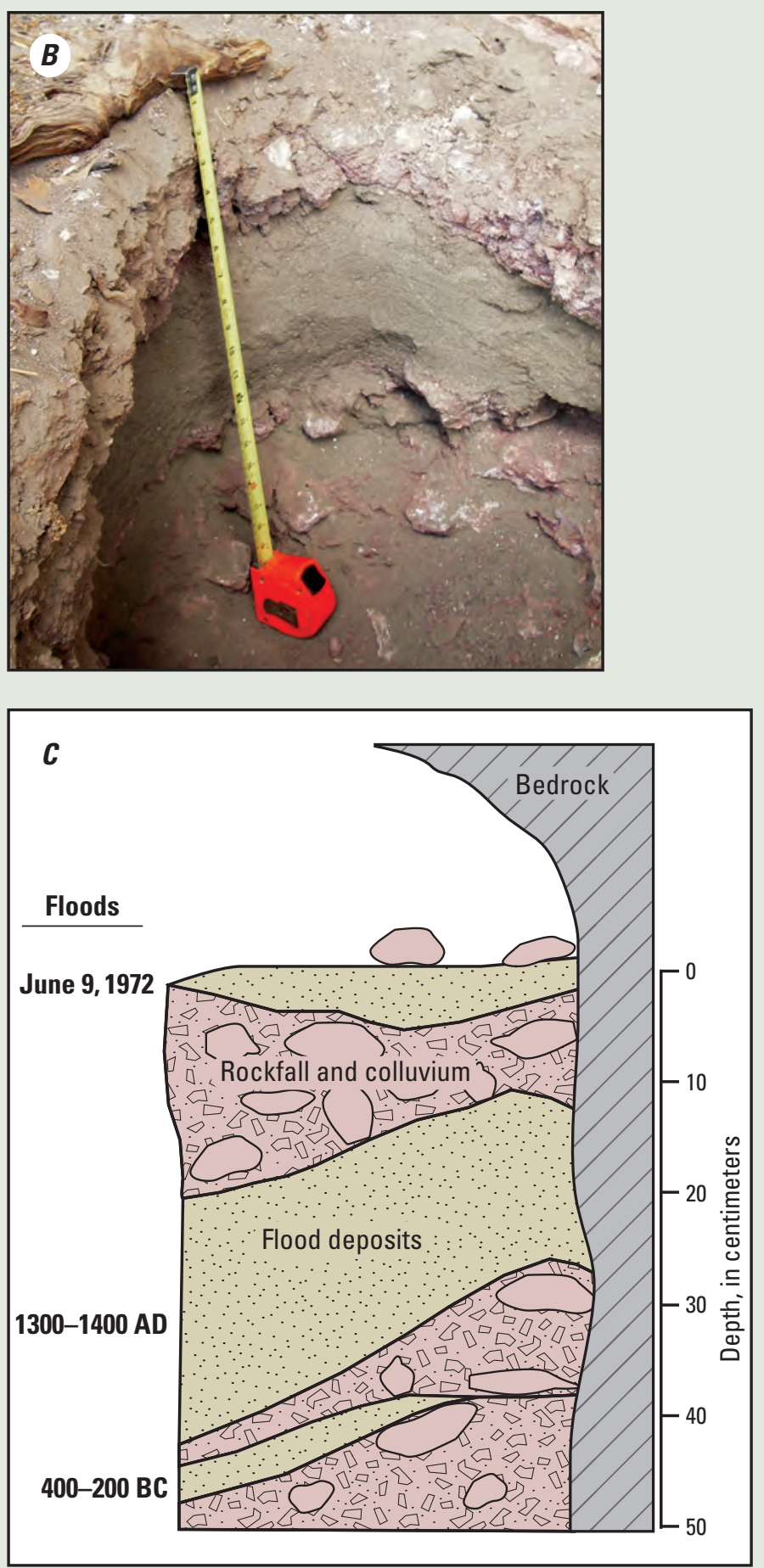


\section{Deschutes River, Oregon}

The Deschutes River drains 10,370 square miles of central Oregon before entering the Columbia River about 100 miles east of Portland, Oregon. Hosman and others (2003) led a paleoflood analysis of the Deschutes River to assess the existing spillway design capacity for the Pelton-Round Butte hydroelectric project. The project is a set of three hydropower dams and river regulating structures operated by Portland General Electric and the Confederated Tribes of Warms Springs, 100-112 miles upstream from the river mouth.

The Deschutes River is not typically associated with paleoflood studies; the river is not within a vertical-walled canyon with abundant overhangs and alcoves. The river downstream from the dam complex is alluvial and flanked by alluvial surfaces for most of its length within a valley incised in Tertiary and Quaternary volcanic and sedimentary rocks.

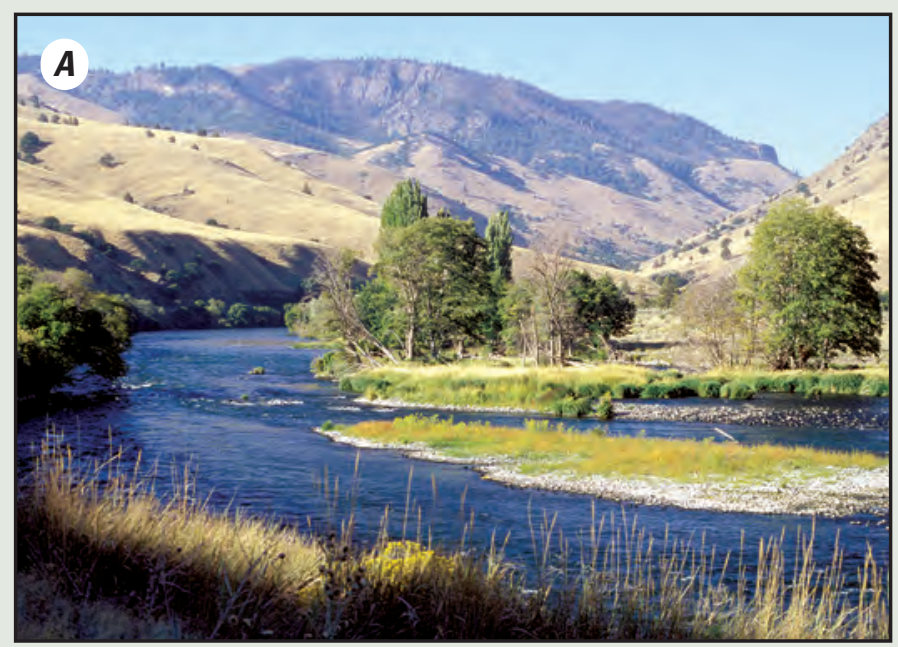

$A$, The Deschutes River, near Dant, Oregon (station number 14097120; http://dx.doi.org/10.5066/F7P55KJN) and B, Deschutes River flood plain stratigraphy, showing at least five deposits of overbank silt, sand, and gravel left by large flood events (Hosman and others, 2003).
Nevertheless, distinct overbank deposits in the flood plain stratigraphy record large floods extending back 5,000 years (Hosman and others, 2003). Although no single site contained a complete record, a com-

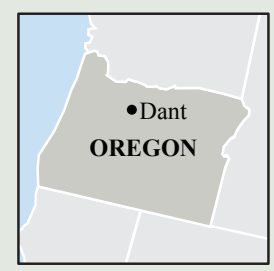
posite record was compiled from multiple sites. An example of a site with a comprehensive record is near Dant, Oreg., where three distinct flood plain levels contain different but overlapping flood records, probably including deposits of the largest historic (but unmeasured) flood of 1861, a similar-sized flood about 1,300 years ago, and an even larger flood - informally termed the Outhouse flood — of about 4,600 years ago. Paleodischarge estimates were determined by relating the surveyed elevations of these deposits to a step-backwater model of water surface profiles developed for each reach.

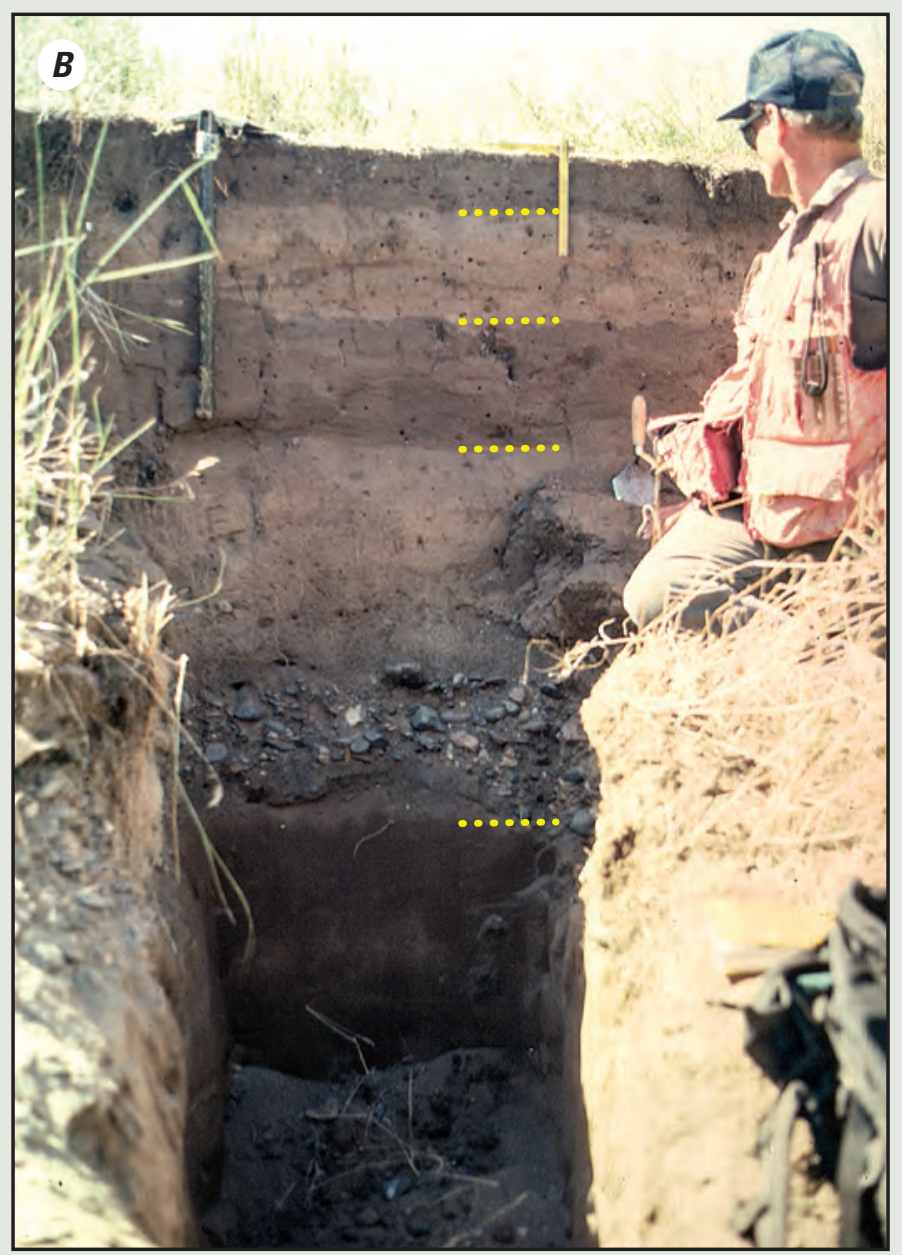


Publishing support provided by: Rolla Publishing Service Center

For more information concerning this publication, contact: Chief, USGS Office of Surface Water

415 National Center

12201 Sunrise Valley Drive

Reston, VA 20192

(703) 648-5301

Or visit the Office of Surface Water Web site at: http://water.usgs.gov/osw/ 
Back cover. Left: Historical flood markers near the Great Falls of the Potomac River, Maryland and Virginia. Photograph by James O'Connor, USGS.

Upper center: Historical flood markers near the Great Falls of the Potomac River, Maryland and Virginia. Photograph by T.A. Cohn, USGS.

Upper right: High-water measurement staff. 
